\title{
Taxonomic novelties in African Dracaena (Dracaenaceae)
}

\author{
T.H.J. Damen ${ }^{1}$, W.J. van der Burg ${ }^{2}$, J. Wiland-Szymańska ${ }^{3}$, M.S.M. Sosef ${ }^{4}$
}

Key words

Africa

Central Africa

Dracaena

Gabon

Lucky Bamboo

new species

taxonomy

\begin{abstract}
In preparing the treatment of Dracaena for Flore du Gabon and Flore d'Afrique centrale, a relatively high number of taxonomic and nomenclatural novelties were discovered; these are presented here. Within Dracaena five species and one forma are described as new, $D$. bushii, $D$. haemanthoides, $D$. marina, $D$. wakaensis, $D$. waltersiae and $D$. laxissima forma aureilicia. Each new species is provided with a full description and taxonomic notes. Apart from that, five species are reinstated, $D$. braunii, $D$. nitens, $D$. perrottetii, $D$. tholloniana and $D$. usambarensis. A further 23 names are treated here as a synonym for the first time: $D$. bequaertii, $D$. buettneri, $D$. cuspidibracteata, $D$. densifolia, D. gabonica, D. gazensis, D. ledermannii, D. letestui, D. litoralis, D. longipetiolata, D. monostachya var. angolensis, $D$. oddonii, D. perrottetii var. minor, $D$. poggei, $D$. pseudoreflexa, D. reflexa var. buchneri, $D$. rubroaurantiaca, $D$. soyauxiana, D. talbotii, D. tessmannii, D. usambarensis var. longifolia, D. vanderystii and Pleomele heudelotii, while for four names a neotype and for 14 names a lectotype has been designated. Distribution maps are provided for a total of 23 species. An index of taxon names is included.
\end{abstract}

Published on 15 May 2018

\section{INTRODUCTION}

The genus Dracaena L. has approximately 116 species, of which some 63 occur in Africa (incl. Madagascar) (Govaerts et al. 2017). The remainder is found in Asia, Australia and Central America. Most recent studies generally place the genus in the family Asparagaceae subfamily Nolinoideae (Stevens 2001 onwards, Lu \& Morden 2014, Angiosperm Phylogeny Group 2016), but others have placed it in Agavaceae (i.e., Hepper $1968 b)$ or recognised it as a distinct family, Dracaenaceae, along with the genera Sansevieria Thunb. and Pleomele Salisb. (Bos 1992, 1998, Watson \& Dallwitz 1992 onwards).

Various species of Dracaena have a high importance in horticulture (Singh \& Dadlani 2000, Wijsman 2012), while others show medicinal (Staner \& Boutique 1937) or social functions in marking graves, sacred sites and farm plots in many African societies (Sheridan 2008). Globally, Dracaena is in the top ten of most important crops in floriculture (Singh \& Dadlani 2000), while in the Netherlands Dracaena is in the top five of the most exported pot plants with an annual turnover of c. 33 million euro (Wijsman 2012). It is remarkable that, even despite this importance, the taxonomy of various species is still unstable, while new species are being discovered on a regular basis (Mwachala et al. 2007, Mwachala \& Fischer 2013), even in such well-studied places as the Canary Islands (Marrero et al. 1998).

Back in 2006, the first author started his investigations in Dracaena at Wageningen University, The Netherlands (WAG), by sorting out the enormous legacy left by the Dracaena specialist J.J. Bos (1939-2003). This legacy was composed of herbarium loans from all over the world, living plants in the greenhouse,

\footnotetext{
Independent scholar, Generaal Foulkesweg 94, 6703 DS Wageningen, The Netherlands;

corresponding author e-mail: dracaenaworldwide@hotmail.com.

2 Naturalis Biodiversity Center, P.O. Box 9517, 2300 RA Leiden, The Netherlands.

${ }^{3}$ Department of Plant Taxonomy, Adam Mickiewicz University, Poznań, Umultowska 89, 61-614 Poznań, Poland.

${ }^{4}$ Meise Botanic Garden, Nieuwelaan 38, B-1860 Meise, Belgium.
}

pictures, literature and notes. The written data was digitized and a database compiled with all herbarium collections, before they were returned to their respective owners. The database, which is maintained by the first author, now contains data on more than 9400 African specimens and on some 14000 from elsewhere. Where possible, specimens were georeferenced and photographed.

During his Dracaena investigations, Bos had already recognised several new African species, but never came to publish these. He was also convinced that flower length was extremely variable and not a good character for species delimitation. In personal communication, Bos often referred to the type material of Dracaena mannii Baker which had led him to this conclusion: "The Berlin isotype of $D$. mannii for instance includes a considerably larger flower than any of its duplicates in other herbaria. Under these circumstances I fully endorse Hutchinsons view to treat them as one variable species" (Bos 1984). However, it turns out that the Berlin isotype (Mann 2329) consists of an inflorescence with smaller flowers while an envelope attached to the sheet contains a distinctly larger flower. With all other isotype sheets (at $P, K$ and WAG) having flowers of the same much smaller size, we hypothesize that the single larger flower on the Berlin sheet does not belong to the same specimen/collection and was put there by accident. This unfortunate situation has thus led to a misconception of flower size as an unimportant character in Dracaena taxonomy! During our long experience with this genus, we have now learned that flower size is an important character, very useful for species recognition, and concluded that as a consequence Bos' species concept was often too wide. As a consequence, some names treated as synonym by Bos need to be reinstated as accepted species (De Roos 2014). For South Africa, Venter (1996) came to the same conclusion and reinstated $D$. transvaalensis Baker which Bos (1992) had treated as a synonym of $D$. aletriformis (Haw.) Bos. Such clarifications are also important for Dracaena plant breeders who use only a few clones (R. Scheffers, pers. comm.) and such reinstated 'new' species may point them to the potential of the introduction of a wider genetic variation to select from. 
With Dracaena having been revised and treated for West Africa (Hepper 1968b, Bos 1984), southern Africa (Bos 1992), Ethiopia (Bos \& Teketay 1997), tropical East Africa (Mwachala \& Mbugua 2007) and the Zambesiaca region (La Croix 2010), the main gap in African Dracaena knowledge is in the Central African region. The first and second author are engaged in preparing the treatment for Flore du Gabon and Flore d'Afrique centrale. With Gabon harbouring most likely the most speciesrich rainforest in Africa (Sosef et al. 2017), it is not surprising that a relatively high number of taxonomic and nomenclatural novelties were discovered during the preparation of both Flora treatments. Most of these would seem out of place in such a treatment, and are thus published here. Since, apart from the species dealt with below, still others occur in the region covered by both Floras, no key is provided here. For identification, the interested user is referred to those Flora treatments which will appear soon.

\section{MATERIALS AND METHODS}

The study was performed using herbarium material and applying standard herbarium techniques (De Vogel 1987). The vast majority of this material came from BR, BRLU, K, LBV, MO, $P$ and WAG (now at $L$ ), with additions from $A, B, B I S H, B M$, BRUNOY, C, E, EA, FHO, GOET, HUJ, IFAN, IG, L, MA, NY, O, POZG, PRE, SRGH, UC, US and Z. Acronyms of institutes holding herbarium collections follow Thiers (continuously updated). Types not available in one of these were generally studied using the Global Plants facility (JSTOR 2000-2016). Data and illustrations were stored in a local version of BRAHMS 7 (Filer 2001). Most of the living material was studied in the botanic garden Burgers' Zoo, Arnhem, The Netherlands, which houses the biggest collection of Dracaena in the world, thanks to efforts of Bos, Jongkind, Damen and several other WAG collectors. Furthermore, the first author visited the Botanic Garden Meise, the Royal Botanic Gardens Kew, the Muséum national d'Histoire naturelle Paris, the Poznań Palm House, the Botanical Garden of the Adam Mickiewicz University, Poznań, the Botanika Bremen, the Alter Botanischer Garten Göttingen, the Jardín Botánico Canario Viera y Clavijo Gran Canaria, the Arboretum de Sibang Libreville and the Dracaena nursery De Plaats at Honselersdijk, The Netherlands, to study living Dracaena material. Furthermore, in 2013 and 2015, the first author conducted two field trips (together with E.L.A.N. Simons) to Gabon to collect herbarium specimens, living material and to study the plants in situ.

The QGIS program (Quantum GIS Development Team 2017) was used to prepare the distribution maps, together with a layer of the UNESCO Vegetation map of Africa (White 1983).

In Africa, Dracaena is generally easy to propagate; only a small piece of the plant is required to form a new plant, and even when thrown away it may easily root and thus occur as an escape (Damen pers. obs.). Therefore, in the field it is sometimes impossible to tell whether an individual is wild or escaped from cultivation, or was even originally planted but then abandoned. Hence, it is not impossible that in the distribution maps presented here a number of collections from cultivated or escaped plants are incorrectly included.

IUCN conservation status assessments for all Central African species, also those not discussed below, are being prepared and will be published in a separate paper.

\section{RESULTS}

The results are presented below per species/taxon, in alphabetical sequence.

\section{Dracaena acaulis Baker - Map 1}

Dracaena acaulis Baker (1878) 252. - Lectotype (designated here) Welwitsch 3752 (lecto LISU [LISU222113]; isolecto BM [BM000911607], COI [COI00100196]), Angola, Pungo Audongo, cataractas do rio Cuanza, July 1855.

Dracaena rubroaurantiaca De Wild. (1906) 228. — Lectotype (designated here): Dewèvre 169 (lecto BR [BR0000008807441]; isolecto BR [BR0000008807458]), Democratic Republic of the Congo, 20 July 1895, syn. nov.

Sansevieria longifolia Welw. in sched.

Distribution - Cameroon, Gabon, Republic of the Congo, Democratic Republic of the Congo, Angola.

Notes - The protologue of $D$. acaulis cites no specimen, but mentions 'Golungo Alto, regio 2 (1000-2400 pedes) in sylvaticis editioribus et ad rivulorum latera montium de, Alta Queta. Floret Julio.' as a reference. The specimen Welwitsch 3752 matches both the description and the reference to its locality in the protologue. There are several duplicates, but the LISU specimen is the only specimen with labels carrying all locality data of the protologue, a label in the handwriting of J.G. Baker and a plant description very similar to that published in the protologue. Therefore, this specimen has been chosen as the lectotype for $D$. acaulis. It is known that Welwitsch provided specimens collected on different dates and localities with the same number (Albuquerque et al. 2009). The specimens in BM and COI carry the same date (July 1855) as the specimen in LISU and thus probably belong to the same collection and can be regarded as isolectotypes. The other duplicates in K, LISU and $\mathrm{P}$, without dates, as well as those of Welwitsch 3753 (with date April 1856), are disregarded.

Dracaena rubroaurantiaca was described from a plant with the same inflorescence type and leaf shape as $D$. acaulis. In the protologue, De Wildeman compared $D$. rubroaurantiaca with Dracaena fragrans (L.) Ker Gawl only; he probably had not seen any material of $D$. acaulis when describing his new species.

In his unpublished PhD thesis, Mwachala (2005) selected Plate 58 published along with the protologue (De Wildeman 1906: 228 ) as lectotype for $D$. rubroaurantiaca. In this protologue, however, De Wildemann cited: "dans les environs de Malella, 20-juillet 1895 (Alf. Dewèvre)". In BR, two sheets of the specimen Dewèvre 169 were found in a type folder together with Plate 58. One of the two sheets is annotated as 'Dracaena rubro-aurantiaca. De Wild. n.sp.'. Although there is no location written on this sheet, it is cited in Durand \& Durand (1909) with the location 'île du Congo dans les env. de Malela', and the morphology fits the protologue. Thus, although the plate published in the protologue is part of the original material, it is preferred to select a herbarium sheet as the lectotype.

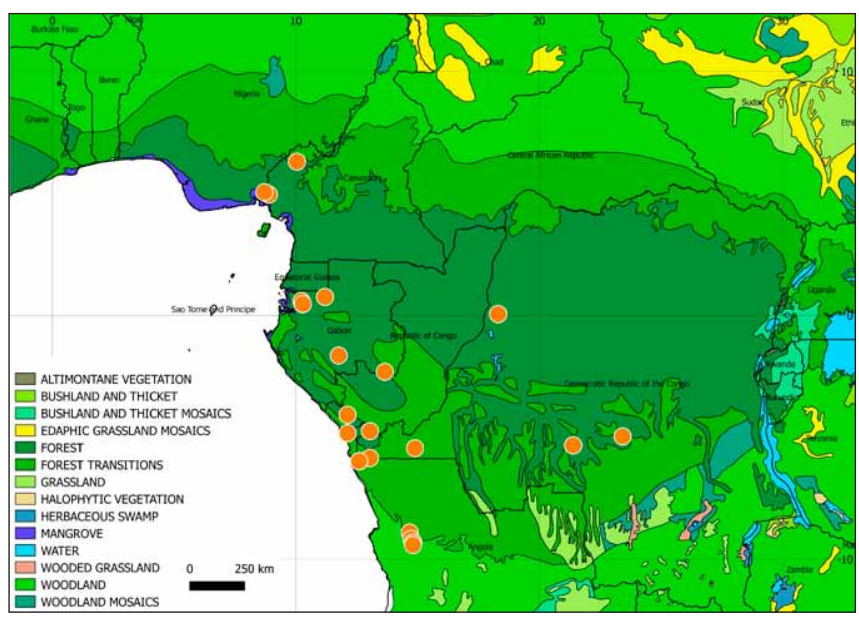

Map 1 Distribution of Dracaena acaulis Baker. 
Sansevieria longifolia Welw. is an unpublished name written on labels mounted on several duplicates of Welwitsch 3752 and Welwitsch 3753.

\section{Dracaena acutissima Hua - Map 2}

Dracaena acutissima Hua (1897) 669. - Lectotype (designated here): Thollon 913 (lecto P [P00442404]; isolecto B, K (drawing), P (2×), WAG), Republic of the Congo, rivière Alima, Mar. 1888

Distribution - Gabon, Republic of the Congo, Democratic Republic of the Congo.

Notes - In his unpublished PhD thesis, Mwachala (2005) selected a neotype for $D$. acutissima. However, in the protologue Hua wrote: "Région de l'Alima (Thollon, $n^{\circ}$ 913), terrains sableux, sous-bois, fl. mars 1888". Material of Thollon 913 is available in several herbaria and hence the selection of a neotype is superfluous. The specimen P00442404 was chosen as the lectotype from among the three sheets available at $P$, since that is the only sheet carrying a label with the details mentioned in the protologue.

\section{Dracaena bicolor Hook. - Map 3}

Dracaena bicolor Hook. (1861) t. 5248. - Lectotype (designated by Bos 1984): Hort. Kew s.n. (lecto K [K000099865]; isolecto K [K000099866]), culta (ex G. Mann s.n., Equatorial Guinea, Fernando Po), Feb. 1861.

Dracaena talbotii Rendle (1913) 112. — Lectotype (designated by Bos 1984): Talbot 1532 (lecto BM [BM000911624]; isolecto BM [BM000911623], K (2×), WAG-spirit), Nigeria, Oban, 1912, syn. nov.

Dracaena densifolia Baker (1874) 165. - Lectotype (designated by Hepper 1968a): Mann 1037 (lecto K [K000099863]), Gabon, Gaboon River, 1861, syn. nov.

Dracaena densiflora Baker (1875) 535 'densifolia'.

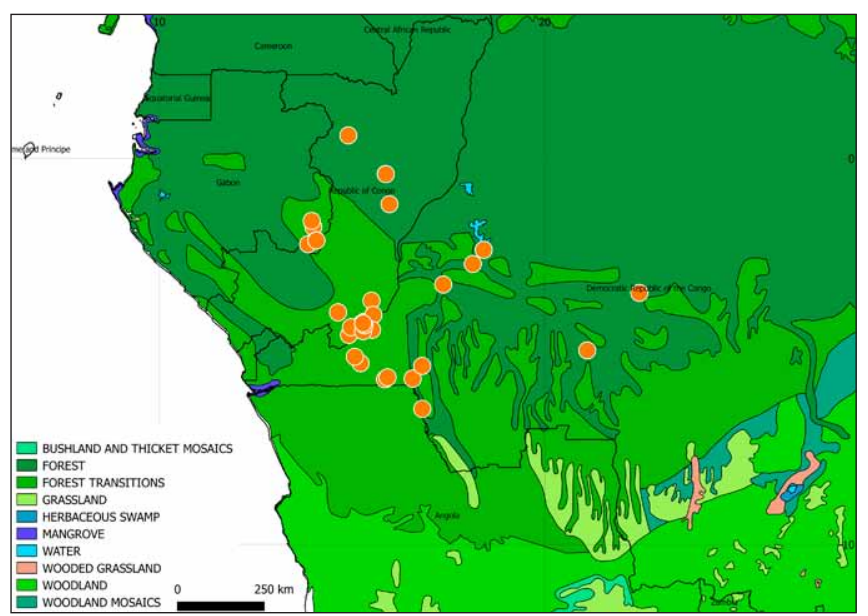

Map 2 Distribution of Dracaena acutissima Hua.

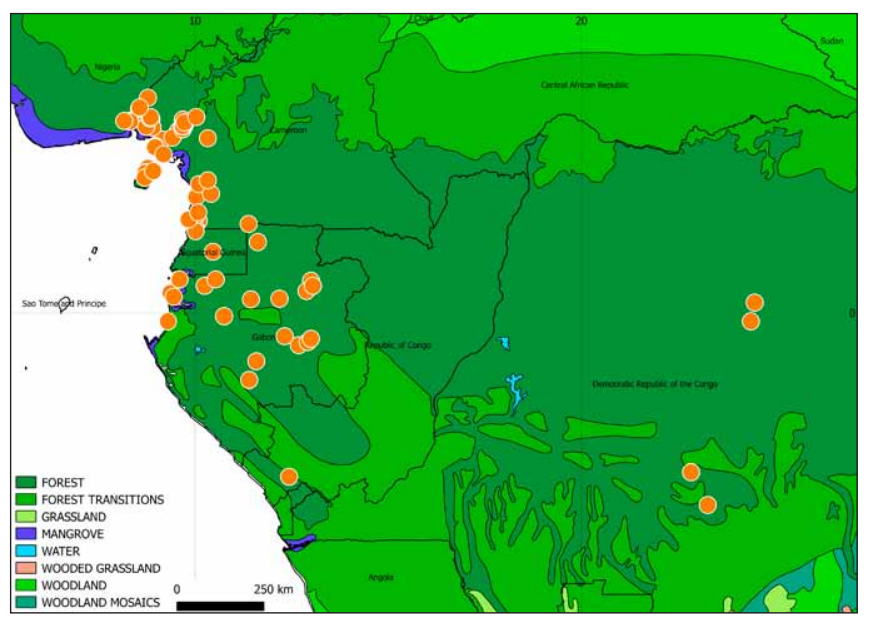

Map 3 Distribution of Dracaena bicolor Hook.
Distribution - Nigeria, Cameroon, Equatorial Guinea, Gabon, Republic of the Congo, Democratic Republic of the Congo.

Notes - In the protologue, Hooker (1861) described the inflorescence of $D$. bicolor s.str. as a dense spicate-capitate compound raceme. Hepper (1968b) stated it is a shortly cylindrical, very dense spike, while according to Bos (1984) the inflorescence is subcapitate to thyrsoid. The inflorescence of $D$. bicolor s.lat. has several (4-10) dense clusters of c. 20 flowers forming a compact bracteate subcapitate inflorescence of up to $26 \mathrm{~cm}$ long. Further anatomic study might reveal that it has a thyrsoid structure, similar to that in Sansevieria (Budweg 2016).

Dracaena talbotii was described from a plant with the same inflorescence type as in $D$. bicolor, but with narrow leaves. We have observed leaf shape to be highly variable within $D$. bicolor (for example the collection Bos 4160 represents two distinct leaf forms collected from the same plant before and after it fell down and re-sprouted), reason why we do not recognise this form as a distinct taxon. Dracaena densifolia represents a form of $D$. bicolor with a more open inflorescence, but otherwise, including flower size, fits well within the range of $D$. bicolor.

\section{Dracaena braunii Engl. — Map 4}

Dracaena braunii Engl. (1892) 479. — Lectotype (designated here): culta Berlin s.n. (lecto B [B 10 0184054]) (ex. Cameroon, Malimba, 1889 Braun 329), Aug. 1891.

Dracaena litoralis Mwachala \& Eb.Fisch. (2013) 444. — Type: Mezili 90 (holo P [P00283988, P00283989]), Cameroon, Kribi District, between Kribi and Lonji, 19 Mar. 1968, syn. nov.

Distribution - Cameroon, Equatorial Guinea, Gabon, Republic of the Congo.

Notes - Dracaena litoralis was recently described to accommodate a plant similar to the original material of $D$. braunii (type and plate in protologue of cultivated plant) but with smaller flowers and different leaf shape. However, we think the difference in the flower size is explained because $D$. braunii was based on cultivated material in which the flower size is often a little larger (phenotypic plasticity due to better growing conditions?). For example, a flower measured in Gabon (Damen et al. 499) was $18 \mathrm{~mm}$ long, but when this plant was transplanted and flowered in the greenhouse at WAG, the flower was $22 \mathrm{~mm}$ long. Flowers in $D$. braunii are nocturnal and only a few hours at full anthesis (Damen, pers. obs.). In the field, collections are usually made when the flowers are not yet at full anthesis and therefore still slightly smaller. In cultivation, where often the light levels are lower, full anthesis starts earlier during the evening and it is easier to collect the flowers at full anthesis. These phenomena could thus well explain the difference in flower size

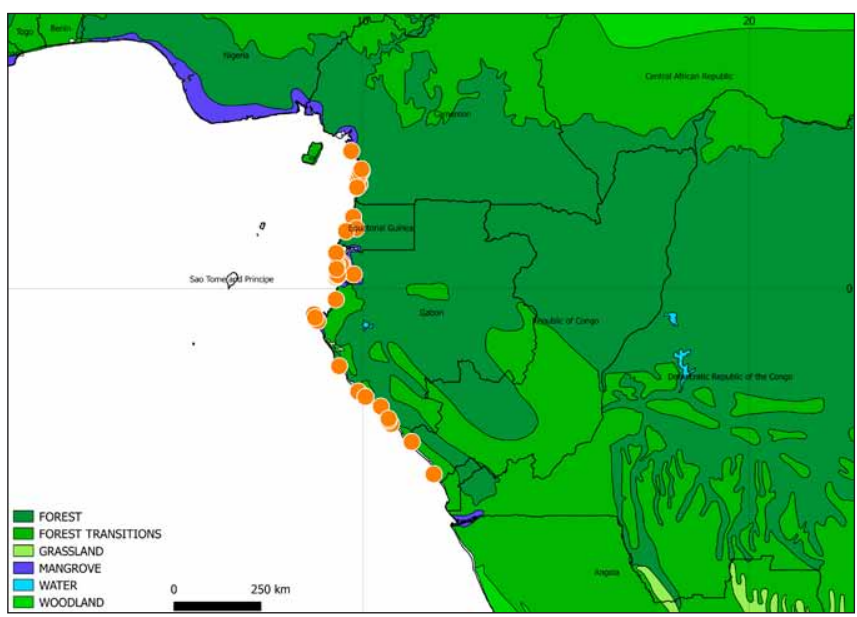

Map 4 Distribution of Dracaena braunii Engl. 

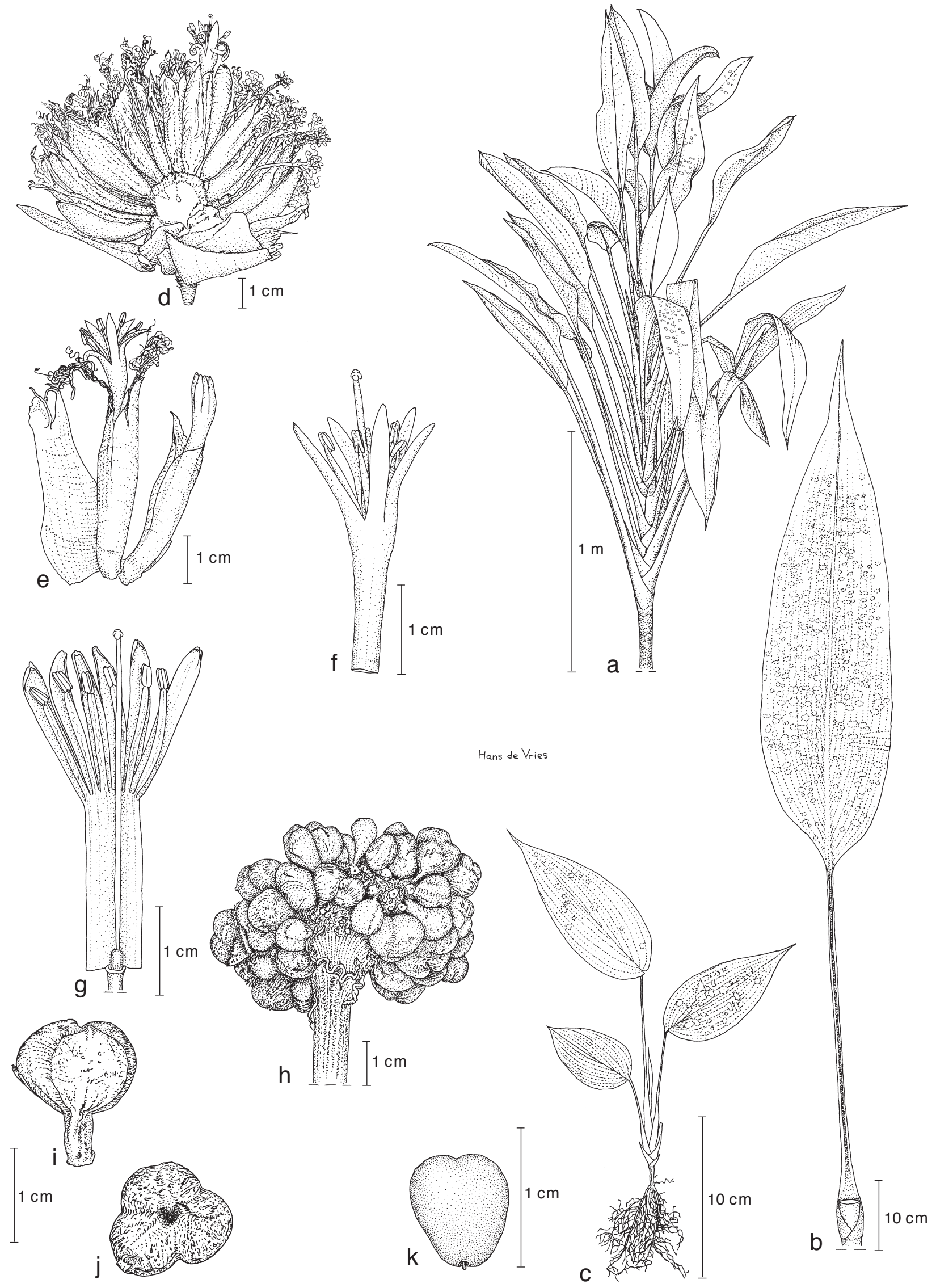

Fig. 1 Dracaena bushii Damen. a. Habit; b. leaf; c. seedling; d. cross section inflorescence; e. part of inflorescence; f. part of flower; g. dissected flower; h. infructescence; i. fruit side view; j. fruit from above; k. single seed (a: culta Burgers Bush n² 20120214025; b, d-g: Van Setten 988; c: Breteler 3043; h-k: Van den Burg 40). - Drawing by Hans de Vries. 
observed by Mwachala \& Fischer (2013). Moreover, we have been able to study $D$. braunii populations in the field, which occurred to be very polymorphic, possibly due to the extreme growing conditions, (salty places near the coast often grazed by buffalos). From those observations we conclude that leaf shape and phyllotaxis of $D$. litoralis fit comfortably within the range of $D$. braunii, as does the characteristic ecology.

In his unpublished PhD thesis, Mwachala (2005) selected Plate 20 in the protologue (Engler 1892: 479) as a lectotype for $D$. braunii. In that protologue, however, Engler cited a cultivated plant: "Die Pflanze wurde von J. Braun nach dem botan. Garten zu Berlin importiert und blühte daselbst im Aug. 1891." According to the label attached to the herbarium sheet in $B$ with barcode B_10_0184054, it represents material from that plant and should thus be regarded as the original material to be preferred over a plate. This corrected typification was already communicated by Mwachala \& Fischer (2013).

\section{Dracaena bushii Damen, sp. nov. - Fig. 1; Plate 1; Map 5}

Dracaena bushii is similar to Dracaena phrynioides Hook., both having capitate inflorescences and leaves with long pseudopetioles. Dracaena bushii is easily distinguished from that species by its flowers which are twice as long and the presence of a distinct stem up to $50 \mathrm{~cm}$ long, and an equitant (with overlapping leaf bases) leaf arrangement, where $D$. phrynioides is subacaulous with its leaves arranged in a rosette. - Type: van Setten 988 (holo WAG [WAG.1152725 (sheet 1), WAG.1152726 (sheet 2), WAG0108898 (spirit), WAG0116789 (spirit)]), culta at Wageningen, The Netherlands, 3 Aug. 1988 (ex Breteler 2438, Cameroon, East Province, 24 km NE of Bertoua, along the road to Bétaré Oya, $\mathrm{N} 4^{\circ} 42^{\prime} \mathrm{E} 13^{\circ} 49^{\prime}$, alt. $750 \mathrm{~m}, 2$ Oct. 1962).

Etymology. Dracaena bushii honours J.J. Bos (the Dutch word 'bos' translates to 'bush' in English) who has been a great inspiration of the first author, and at the same time credits Burgers Bush in Arnhem, The Netherlands, where the largest collection of living Dracaena in the world is being maintained, including a few specimens of $D$. bushii.

Shrub to $2.5 \mathrm{~m}$ tall, with a single stem arising from a woody rhizome; stem to c. $5 \mathrm{~cm}$ diam, up to $50 \mathrm{~cm}$ long, yellowish grey, marked by dark green annular scars of fallen leaves, occasionally forming aerial roots. Leaves alternate, equitant; pseudopetiole bluish dark green, longer than the lamina, to $80 \mathrm{~cm}$ long, sulcate along its upper surface, gradually extending into a sheathing base, clasping the stem for distinctly more than its circumference; lamina ovate, up to 65 by $20 \mathrm{~cm}$, corrugated lengthwise, shiny dark green above, dull pale green beneath, midrib paler, variegated with scattered transversely orientated oval pale green dots, each dot with a yellow centre, coriaceous, leaf base rounded, leaf tip acuminate, mucro to $2 \mathrm{~cm}$ long. Inflorescence terminal, usually erect; peduncle up to $8 \mathrm{~cm}$ long, smooth, terminating in a bracteate capitulum of up to $13 \mathrm{~cm}$ diam; bracts enveloping the capitulum, broadly ovate, c. 5 by $3 \mathrm{~cm}$, scarious, dark brown; flowers in fascicles of 2 or 3 , each fascicle closely enveloped by $3.5-4 \mathrm{~cm}$ long light brown bracts. Flower: pedicel 0-1 mm long; perianth white, $45-50 \mathrm{~mm}$ long, lobes 15 by $2 \mathrm{~mm}$, spreading, each with a single central distinct costa; stamens inserted near the throat, up to $2 \mathrm{~mm}$ shorter than the lobes, filaments white, terete, inflated, with subulate tips, anthers pale yellow, 3 by $1 \mathrm{~mm}$; ovary oblong, up to 3 by $2 \mathrm{~mm}$; style filiform, to $1 \mathrm{~mm}$ exserted, white, stigma capitate, shallowly trilobed, c. $1 \mathrm{~mm}$ diam. Fruits depressed globose, shallowly 1-3-lobed, c. 14 by $9 \mathrm{~mm}$, bright orange to bright red, with 2 or 3 seeds, receptacle of up to $4 \mathrm{~mm}$ long. Seeds smooth, ellipsoid, up to c. 10 by $7 \mathrm{~mm}$, flattened where pressed against adjacent seeds.

Distribution - Cameroon, Equatorial Guinea, Gabon.

Ecology - Understory of secondary forest, forest edges, humid places, on sandy soil and clayish river banks; at 100$1500 \mathrm{~m}$ altitude. Flowering in June (fide Letouzey 13823).

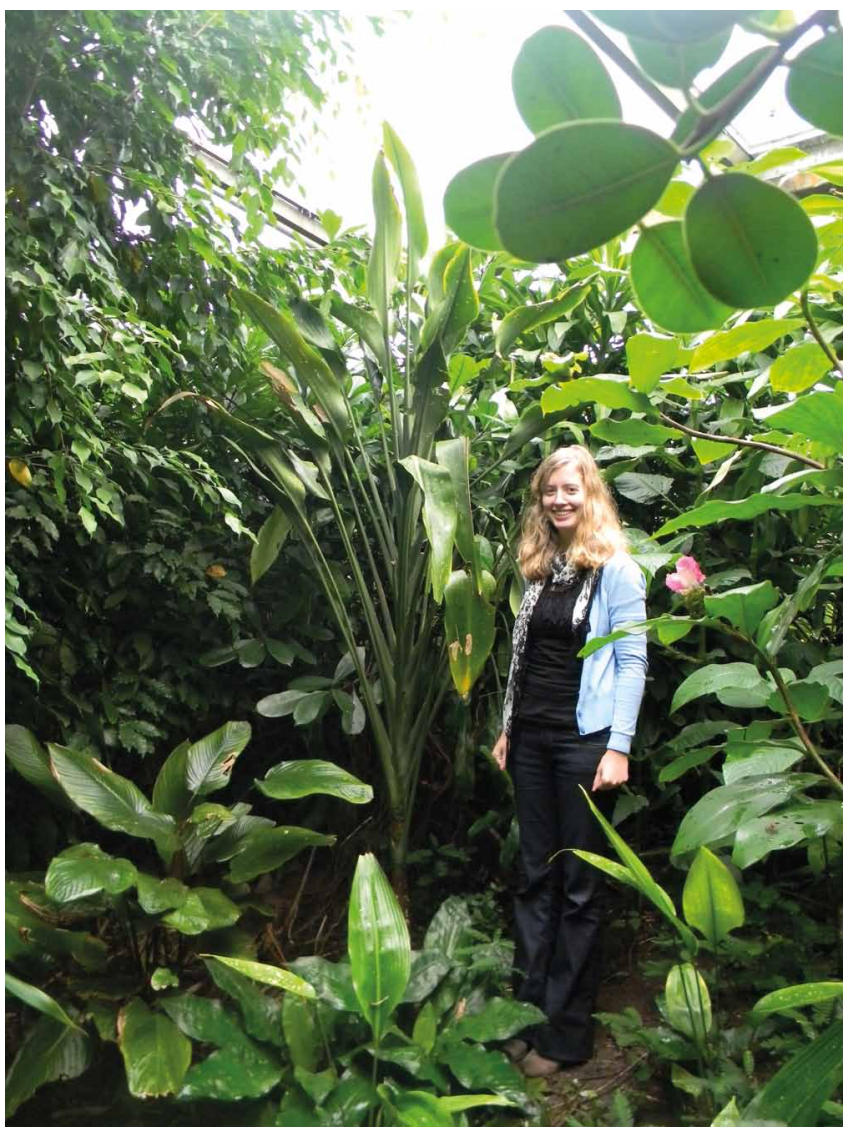

Plate 1 Dracaena bushii Damen, habit and two seedlings with SJ van de Kerke; culta Burgers Bush n² 20120214025. — Photo: THJ Damen.

Other specimens examined. CAMEROon, Centre, Nkolukie dans le massif du Mbam-Minkom 18 km nord-ouest Yaoundé, c. N359' E11 ${ }^{\circ} 23^{\prime}, 28$ Sept. 1984, Achoundong, G 622 (P); East, 24 km NE of Bertoua, along the road to Bétaré Oya, $\mathrm{N}^{\circ} 42^{\prime} \mathrm{E} 13^{\circ} 49^{\prime}$, alt. $750 \mathrm{~m}, 8$ Jan. 1962, Breteler, FJ 2438 (WAG); $500 \mathrm{~m} \mathrm{NW}$ of Koundi, $22 \mathrm{~km} \mathrm{~N}$ of Bertoua, $\mathrm{N}^{\circ} 44^{\prime} \mathrm{E} 13^{\circ} 36^{\prime}$, alt. $670 \mathrm{~m}$, 29 Dec. 1977, Van den Burg, HC 16 (WAG); $1.5 \mathrm{~km}$ S of Yanda I, between Bertoua and Diang, $\mathrm{N}^{\circ}{ }^{\circ} 34^{\prime} \mathrm{E} 13^{\circ} 25^{\prime}$, alt. $720 \mathrm{~m}, 16$ May 1978, Van den Burg, HC 40 (WAG); culta, in greenhouse botanical gardens Wageningen, The Netherlands, (seedling from Breteler et al. 2438 collected in Cameroon, 24 km NE of Bertoua, along the road to Bétaré Oya, N4 ${ }^{\circ} 42^{\prime} \mathrm{E} 13^{\circ} 49^{\prime}$, alt. $750 \mathrm{~m}$ ), 2 Oct. 1962, Breteler, FJ 3043 (WAG); culta in The Bush, Burgers' Zoo, Antoon van Hooffplein 1, Arnhem, The Netherlands, gift from WAG, No. 1969PT00479, (ex Breteler 2438, Cameroon, East Province, 24 km NE of Bertoua, along the road to Bétaré Oya, N4²4' E1349', alt. 750 m, 2 Oct. 1962), 24 Nov. 2011, Damen, THJ 463 (WAG); ibid., 7 Apr. 2013, Roos, JR de 11 (WAG); South, colline Mbok, $5 \mathrm{~km}$ à l'est de Meyo Centre, $40 \mathrm{~km}$ SSW d'Ebolowa, C. N2 ${ }^{\circ} 34^{\prime}$ E11 ${ }^{\circ} 04^{\prime}, 24$ Mar. 1970, Letouzey, R 10228 (P); South-West, colline au SE d'Okororoba, 20 km NE Ngati, c. N5²6' E9¹7', alt. 772 m, 13 June

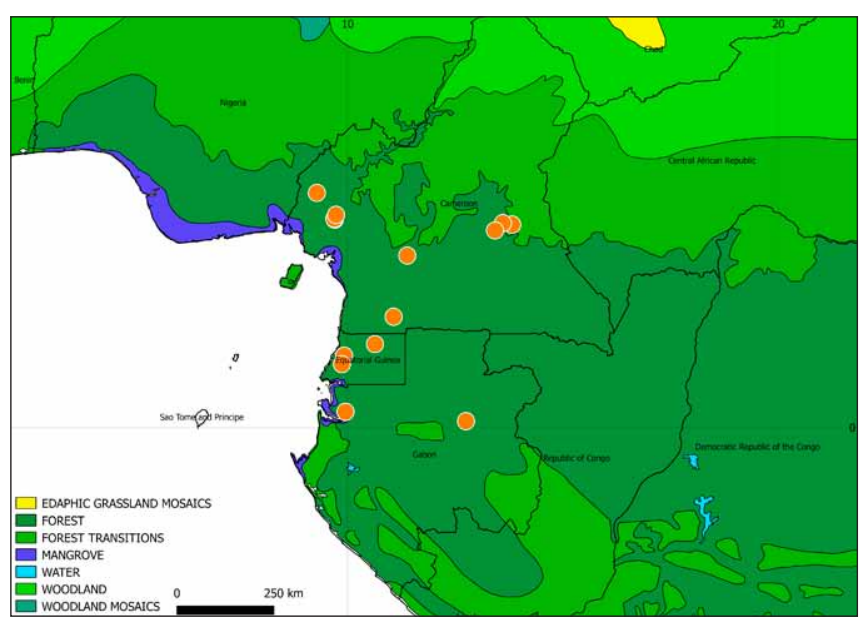

Map 5 Distribution of Dracaena bushii Damen. 
1975, Letouzey, R 13823 (P, WAG-spirit); Mt Kupe, Nyasoso, along Max's trail, N450' E9 ${ }^{\circ} 42^{\prime}$, alt. 1100 m, 2 Dec. 2004, Richardson, JE 250 (WAG); Mt Kupe, Ngomboku, path to the east, N4 $55.6^{\prime} \mathrm{E}^{\circ} 43.7^{\prime}$, alt. $1100 \mathrm{~m}, 3 \mathrm{Dec}$. 2004, Richardson, JE 261 (WAG); Meme, N4²49' E942', alt. 1200-1500 m, 1 Dec. 1985, Thomas, DW 5098 (WAG). - Equatorial Guinea, Litoral, Bata-Senge, Estrada km 38, entrada maderera hacia el monte Bibogo, c. $\mathrm{N} 1^{\circ} 40^{\prime} \mathrm{E} 9^{\circ} 55^{\prime}$, alt. $650 \mathrm{~m}, 13$ May 1997, Carvalho, MF de 6324 (BRLU, MA); SE Bata, c. 50 km Oborobiko, Bata to Rio Benito, c. N1 ${ }^{\circ} 28^{\prime}$ E9 $9^{\circ} 52^{\prime}, 25$ Feb. 1969, Sanford, WW 6027 (K); Wele Nzas, région d'Anisok, env. de Temelon, près du village Ayene, c. N1 ${ }^{\circ} 56^{\prime}$ E10 $1{ }^{\circ} 38^{\prime}, 10$ Sept. 1997, Lisowski, S M614 (BRLU). - GABON, Estuaire, Andem, Kougouleu-Kango c. 10 km, 2 km N, N0²2' E957', 9 Oct. 1985, Louis, AM 1859 (LBV, WAG); Ogooué-Ivindo, Parc National de l'Ivindo, chutes de Djidji, N008.9' E1244.6', alt. 335 m, 28 Mar. 2004, Moungazi, A 1475 (LBV, WAG). - UNKNOWN, culta, Plantentuin, Rijksuniversiteit Gent, Belgium, 15 Nov. 1984, Laan, FM van der 830 (WAG, WAG-spirit); Botanic Garden Meise, Belgium, No. 19073927, origin unknown, 17 Oct. 2017, Caekenberghe, F van 52 (BR-spirit).

Note - The description of Dracaena sp. aff. phrynoides Hook in Cheek et al. (2004) matches the new species D. bushii. Unfortunately, the herbarium at Kew could not locate the three specimens cited in this publication during a recent visit of the first author, and so this could not be checked.

\section{Dracaena camerooniana Baker - Map 6}

Dracaena camerooniana Baker (1874) 166. - Type: Mann 1204 (holo K (K000255899); iso GH, K, P, S, U), Cameroon, Cameroon Mount, Jan. 1862. Dracaena oddonii De Wild. (1906) 227. - Type: Oddon in Gillet 3333 (holo BR (BR0000008807397); iso BR (BR0000008807380)), Democratic Republic of the Congo, Janda, 1903, syn. nov.

Dracaena silvatica Hua (1897) 665. - Type: Thollon 4074 (holo P (P00442299); iso WAG (WAG0184575)), Republic of the Congo, Brazzaville, May 1891.

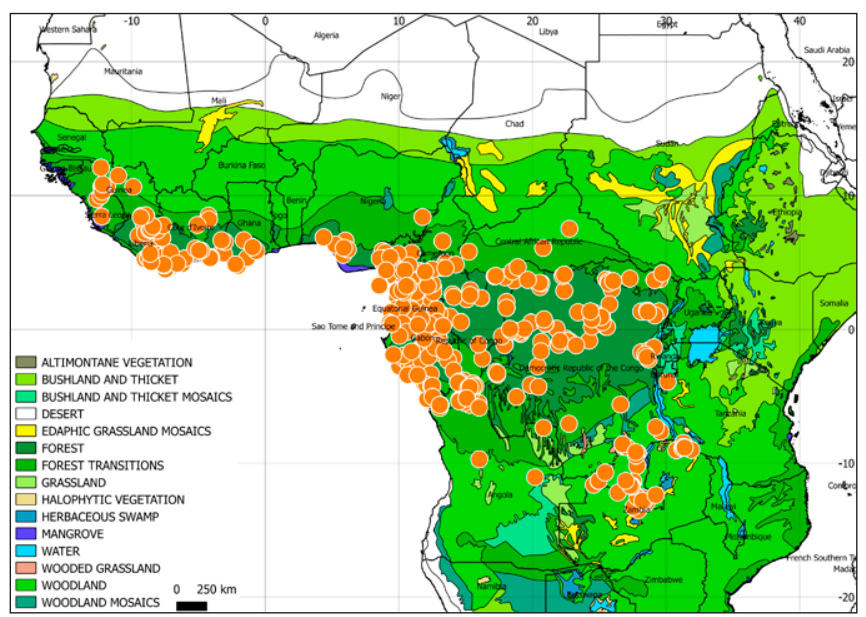

Map 6 Distribution of Dracaena camerooniana Baker.

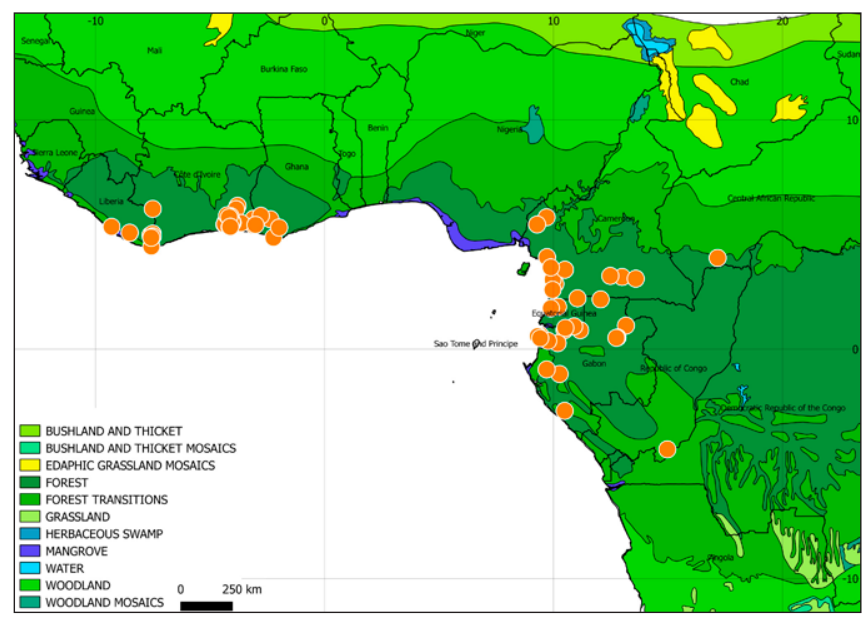

Map 7 Distribution of Dracaena cerasifera Hua.
Distribution - Guinea, Sierra Leone, Liberia, Ivory Coast, Ghana, Nigeria, Cameroon, Equatorial Guinea, Gabon, Central African Republic, Republic of the Congo, Democratic Republic of the Congo, Tanzania, Angola, Zambia.

Notes - Dracaena oddonii was described from a plant with larger leaves and a longer petiole than the typical $D$. camerooniana. We do not recognise this form as a distinct taxon, because leaf shape within $D$. camerooniana is highly variable and both leaf forms can occur even on the same plant (Damen, pers. obs.).

Dracaena silvatica was described from a plant with much smaller flowers than typical $D$. camerooniana. This ecotype has been observed several times in the wild and grows in deep shade and inundated forest where the flowers and fruits are often poorly developed or even malformed (Damen, pers. obs.). It is regarded as a phenotype not worthy of a distinct taxonomic rank.

\section{Dracaena cerasifera Hua - Map 7}

Dracaena cerasifera Hua (1897) 663. - Lectotype (designated here): Leroy s.n. (lecto P (P00442279); isolecto K (K000255922), P (P00442280, P00442281), WAG (WAG0251836)), Gabon (Congo français), Ogoué, 1894-1895.

Distribution — Liberia, Ivory Coast, Ghana, Cameroon, Equatorial Guinea, Gabon, Central African Republic, Republic of the Congo.

Note - In the protologue, Hua gives 'Ogooué (Mgr Leroy)' to indicate the material seen. This material is represented at $P$ by three sheets, two with flowers and one with fruits, which match the description provided in the protologue. The sheet chosen here to serve as lectotype is richest in flowers.

\section{Dracaena congoensis Hua - Map 8}

Dracaena congoensis Hua (1897) 668. - Type: Thollon s.n. (holo P (P00442278); iso K-drawing \& fragment (K000255935), WAG-fragment (WAG0010776)), Republic of the Congo, Forêt de Mayumba, 1890-1891. Dracaena cuspidibracteata Engl. (1902) 96. - Type: Zenker 1616 (holo B (B_10_0160844); iso BM, COI, E, G, GOET, HBG, K, L, M, MO, P, PRE, $\mathrm{S}, \mathrm{WAG}, \mathrm{WU}, \mathrm{Z})$, Cameroon, Bipindi, 22 Dec.1897, syn. nov.

Distribution - Guinea, Ivory Coast, Ghana, Togo, Benin, Nigeria, Cameroon, Gabon, Central African Republic, Republic of the Congo, Democratic Republic of the Congo.

Note - Dracaena cuspidibracteata was described from a plant that fits well the inflorescence and leaf shape characteristics of $D$. congoensis. In the protologue, Engler compared

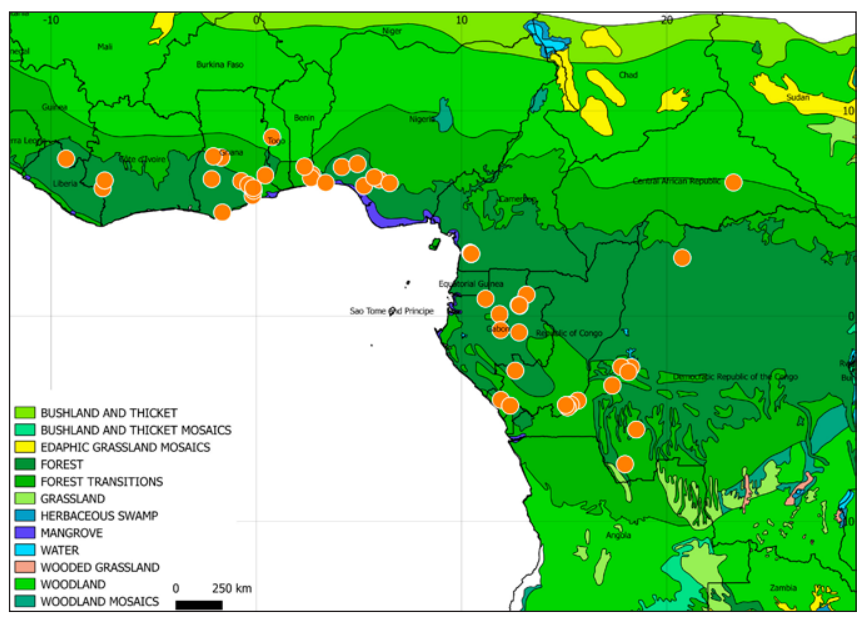

Map 8 Distribution of Dracaena congoensis Hua. 
$D$. cuspidibracteata only with $D$. fragrans and we assume he had not seen any material of $D$. congoensis when describing his new species.

\section{Dracaena glomerata Baker - Map 9}

Dracaena glomerata Baker (1874) 166. - Type: Mann 1630 (holo K (K000255925); iso K (K000255926), P), Equatorial Guinea, Corsico Bay, lloby Island, Aug. 1862.

Dracaena buettneri Engl. (1892) 478. — Type: Büttner 537 (holo B (B_10_ 0160843)), Gabon, Wald bei Sibange, Sept. 1884, syn. nov.

Dracaena gabonica Hua (1897) 669. — Lectotype (designated here): Soyaux 98 (lecto P (P00487007); isolecto K (K000255923)), Gabon, in ditione Munda, Sibange-Farm, 16 July 1880, syn. nov.

Dracaena soyauxiana Baker (1901) 857. - Lectotype (designated here): Soyaux 158 (lecto Z (Z-000075491)), Gabon, in ditione Munda, SibangeFarm, 13 Nov. 1880, syn. nov.

Distribution - Cameroon, Equatorial Guinea, Gabon, Republic of the Congo, Democratic Republic of the Congo.

Notes - Dracaena buettneri, D. gabonica and D. soyauxiana represent the same species collected at the same locality (Gabon, Sibang area) in different stages of growth, respectively. with young inflorescence, at anthesis and fruiting. They all represent a form with a spicate inflorescence, while the other extreme of the variable inflorescence shape, a short and branched inflorescence, is represented by the type specimen of $D$. glomerata. Since all intermediate inflorescence forms can be found (Damen, pers. obs.), we do not recognise them as distinct taxa.

The protologue of $D$. gabonica mentions two collections: Soyaux 98 and Klaine 104; the Soyaux specimen at $P$ with both leaves and an inflorescence is most suited to serve as the lectotype. The protologue of $D$. soyauxiana cites Soyaux 158 as the type and states 'Ad D. ellipticum Thunb., accedit' [close to Dracaena elliptica Thunb. \& Dalm.]. However, at K, where we first expected to find the holotype, Soyaux 158 represents a Combretaceae (Combretum platypterum (Welw.) Hutch. \& Dalziel). The original label gives 'Cacoucia paniculata Laws.', which is a synonym of that species. Baker, publishing his new species in the Bulletin de l'Herbier Boissier, probably saw the sheet at Z, where Soyaux 158 indeed represents this taxon, though the label also carries the Combretaceae name. Obviously some mixture of labels and/or plants has taken place. Even more confusing is that at $\mathrm{K}$ the label of Soyaux 98 , the isotype of $D$. gabonica, carries the remark 'n.sp.? near elliptica'. It might thus even be that Baker actually intended to assign Soyaux 98 as the type.

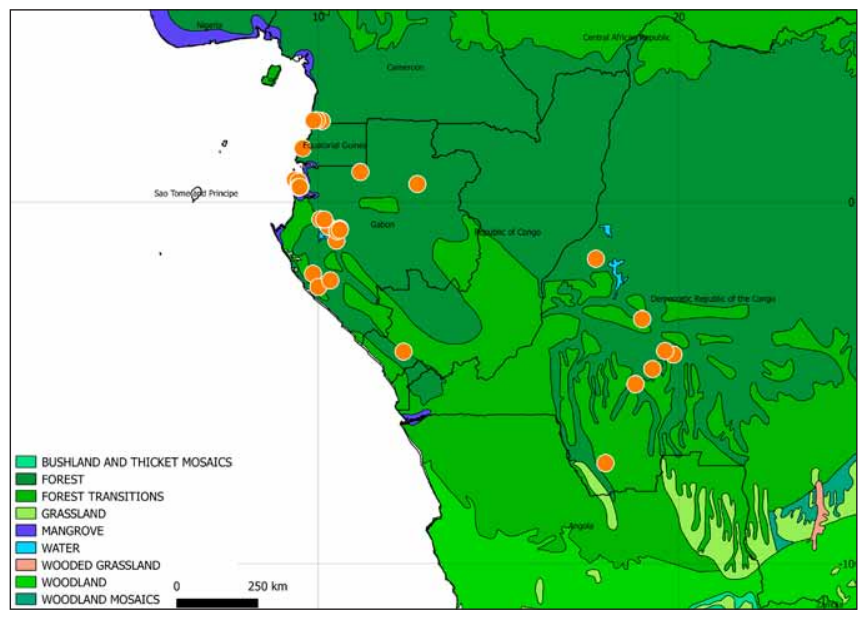

Map 9 Distribution of Dracaena glomerata Baker.

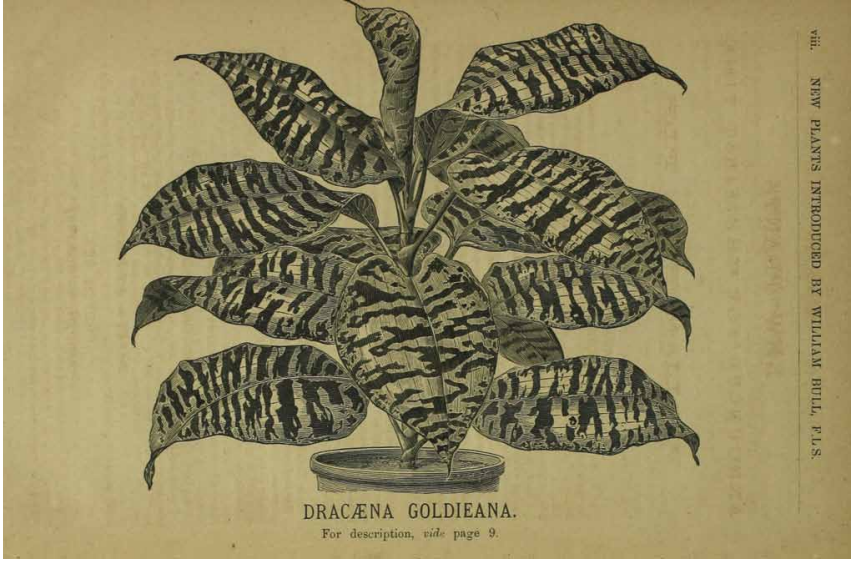

Plate 2 Iconotype Dracaena goldieana Bullen ex Mast. \& T.Moore from Bull (1877), Retail list, No 129: t. VIII.

10. Dracaena goldieana Bullen ex Mast. \& T.Moore - Plate 2; Map 10

Dracaena goldieana Bullen ex Mast. \& T.Moore (1872) 1232. - Neotype (designated here): Bull (1877), Retail list, No 129: $t$. VIII (iconotype).

Distribution - Nigeria, Cameroon, Equatorial Guinea, Gabon, Democratic Republic of the Congo.

Note - The protologue describes a plant exhibited in 1872 by Robert Bullen of the Glasgow Botanic Gardens. No herbarium material of the original plant seems to have been preserved. Although we could not find direct proof of the statement by Bos (1984) that William Bull received plants of $D$. goldieana from Edinburg Botanic Garden, it is a highly likely assumption that William Bull received material from this same plant and published the drawing carrying that name in his Retail List (Bull 1877). This drawing thus represents the material closest to the original cultivated plant and we decided to select that as the neotype.

\section{Dracaena haemanthoides Bos ex Damen, sp. nov. -}

Fig. 2; Plate 3; Map 11

Dracaena haemanthoides is similar to the West African Dracaena adamii Hepper; both are found on streambanks and share the same phyllotaxis and inflorescence type. Dracaena haemanthoides is easily distinguished, however, because its flowers are almost 2 times as long as those of $D$. adamii while the corolla lobes are much shorter than the tube. Furthermore, the peduncle is smooth, not scabrid as in D. adamii. - Type: Veldhuizen, $J$ van 982 (holo WAG [WAG.1153971 (sheet 1), WAG.1153970 (sheet 2), WAG0116648 (spirit)], culta, in greenhouse at Wageningen, The Netherlands (No. 1972PT00634 ex Leeuwenberg, AJM 10334, 16 Sept. 1972, 14 km E of Kumba, $28 \mathrm{~km} \mathrm{~W}$ of Loum., N4²41' E9³1'), 26 Jan. 1984.

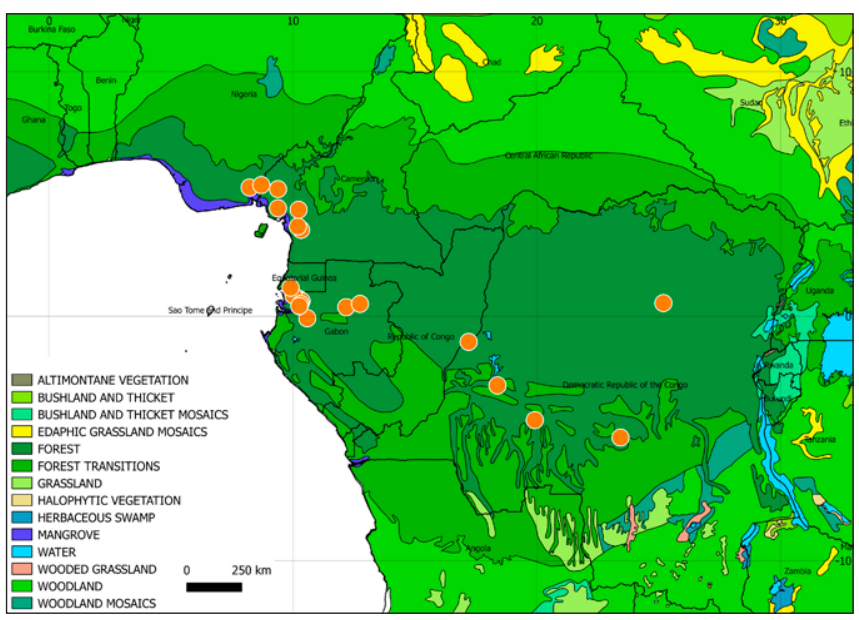

Map 10 Distribution of Dracaena goldieana Bullen ex Mast. \& T.Moore. 
Etymology. Bos did already recognise this species as distinct and provisionally named it $D$. haemanthoides on his identification slips (fide Bos 10828), probably because it resembles the growth habit and capitate flowers of some species of Haemanthus.

Shrub, single-stemmed or occasionally acaulescent, up to c. $50 \mathrm{~cm}$ high; stem unbranched, erect, up to c. $20 \mathrm{~cm}$ long, densely leafy towards the top, greenish. Leaves alternate, equitant; pseudopetiole broadly winged, gradually extending into a sheathing base, clasping the stem for slightly more than its circumference; lamina oblanceolate or narrowly elliptic in smaller specimens, up to 80 by $12 \mathrm{~cm}$, thickly coriaceous, glossy dark green above, pale green or occasionally dark purple with midrib prominent for c. 3/4 of its length beneath, base gradually tapering, apex acuminate, subulate, mucro up to $3 \mathrm{~mm}$ long. Inflorescence terminal, erect, up to $18 \mathrm{~cm}$ long; peduncle smooth, purplish green, base with cuspidate transitional leaves, merging into purplish green cymbiform bracts of up to 16 by $10 \mathrm{~mm}$ which subtend the closely packed glomerules containing well over 10 flowers each, forming a subcapitate inflorescence. Flower: pedicel 1-2 mm long, persistent basal part to $1.5 \mathrm{~mm}$ long; perianth creamy white, $51-59 \mathrm{~mm}$ long, tube longitudinally striped, pink-purple on the outside, lobes reflexed, c. 11 by $3 \mathrm{~mm}$, apex obtuse with minute mucro, outside greenish white, inside white; stamens inserted near the throat, up to $1 \mathrm{~mm}$ shorter than the lobes, filaments filiform, white, anthers c. $1.5 \mathrm{~mm}$ long, pale yellow; ovary ovoid, 3 by
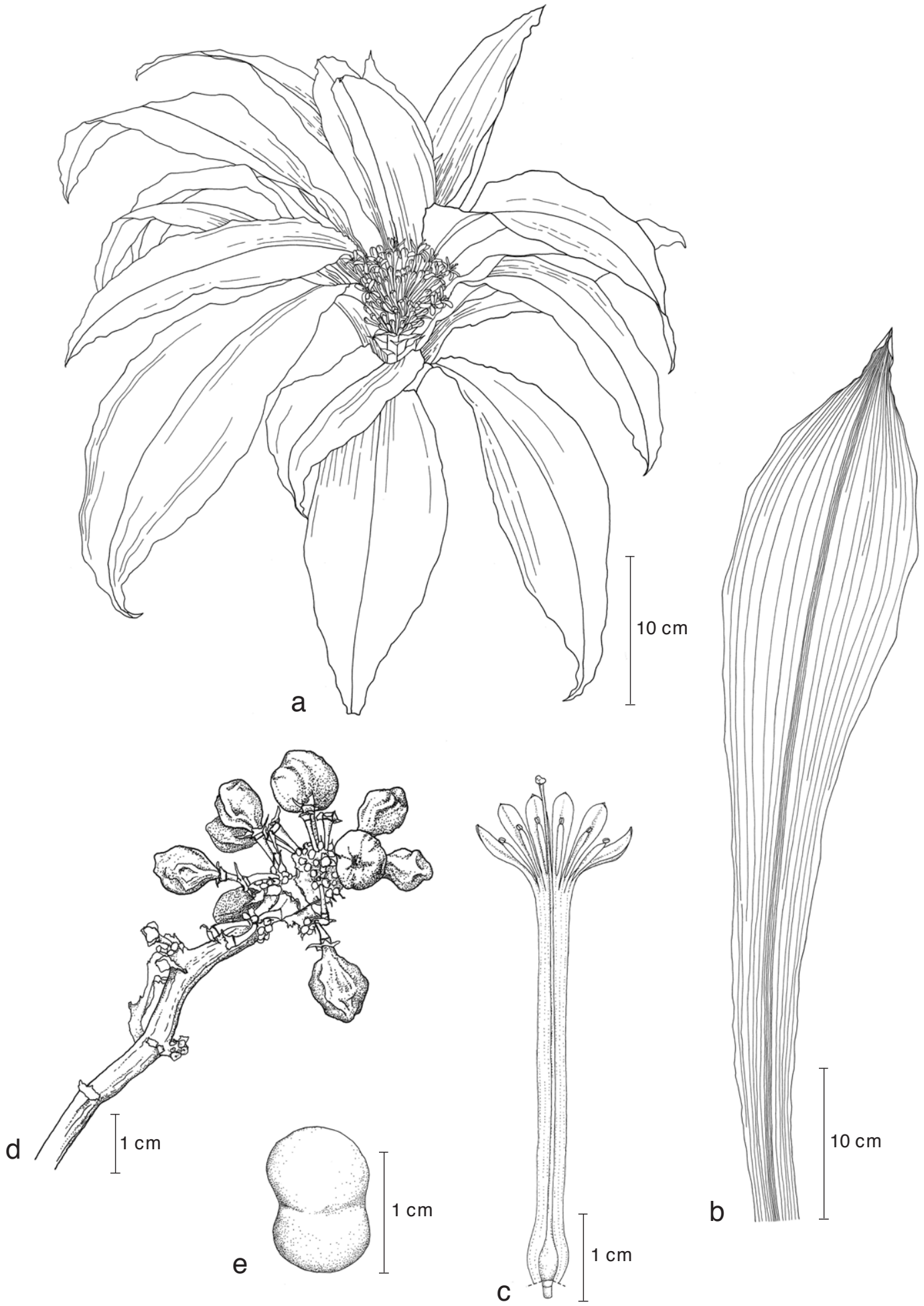

Fig. 2 Dracaena haemanthoides Bos ex Damen. a. Habit; b. upper part of leaf; c. dissected flower; d. infructescence; e. seed (a: culta Hort. Bot. Wageningen n 1972PT00634; b: Van Setten 1061; c: Van Setten 991; d: Van Veldhuizen 1539; e: Van Veldhuizen 982). - Drawing by Kinga Berdysz. 


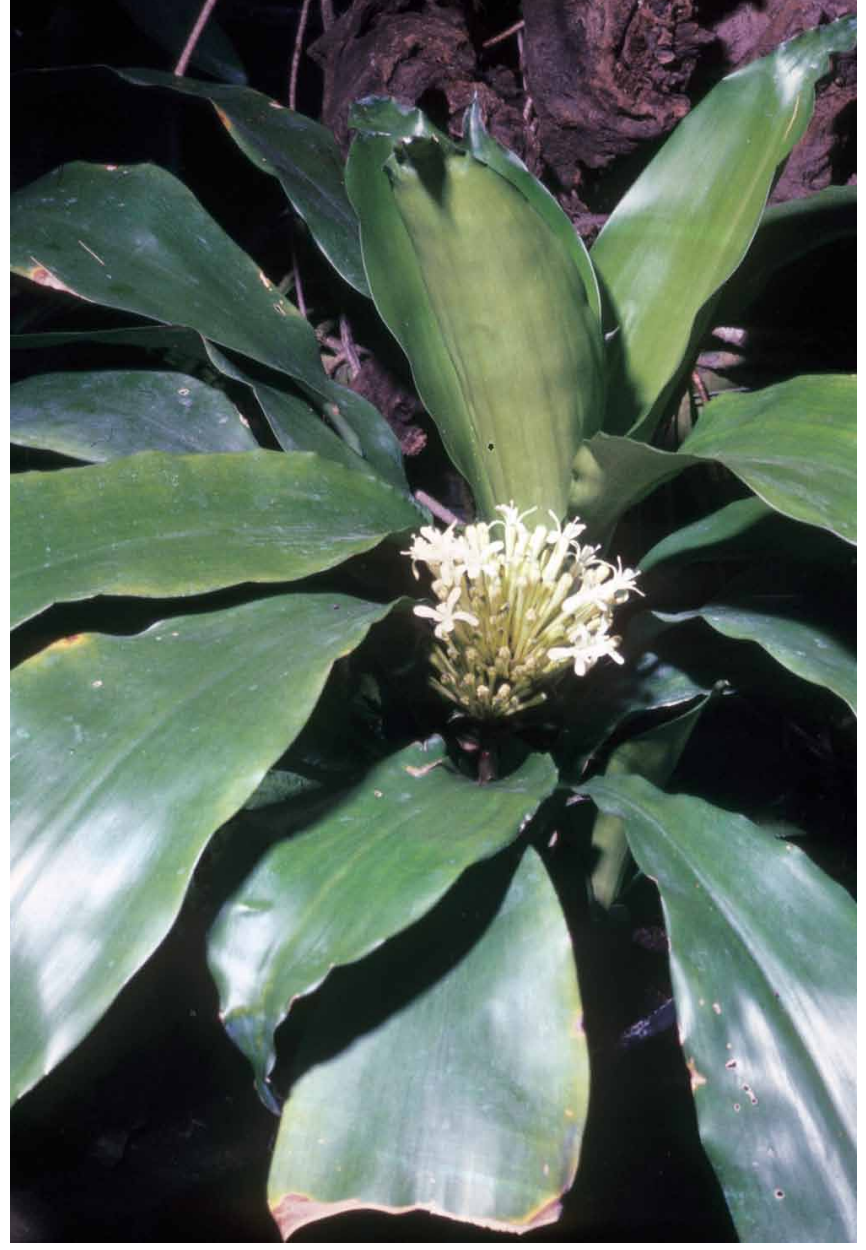

Plate 3 Dracaena haemanthoides Bos ex Damen, habit and inflorescence; culta greenhouse WAG n 1984PTCB057A. — Photo: JJ Bos.

$2 \mathrm{~mm}$; style filiform, to $2 \mathrm{~mm}$ exserted, white; stigma capitate, 3-lobed, $1 \mathrm{~mm}$ diam. Fruits broadly ellipsoid, c. 18 by $21 \mathrm{~mm}$, orange to yellow, receptacle to $3 \mathrm{~mm}$ long. Seeds broadly ellipsoid, shallowly bilobed, 8 by $12 \mathrm{~mm}$, smooth.

Distribution - Cameroon, Gabon, Equatorial Guinea.

Ecology - Creek banks in forest, on flat loamy banks of shallow forest streamlet; at $25-450$ m altitude. Flowering period unknown, but in cultivation in The Netherlands, it flowered in January and February.

Other specimens examined. CAmEROon, South, $12 \mathrm{~km}$ from Kribi, S. of Lolodorf road, towards Kienke river, c. N2 ${ }^{\circ} 59^{\prime}$ E9 ${ }^{\circ} 59^{\prime}, 9$ July 1970, Bos, JJ 7065 (WAG); South-West, $14 \mathrm{~km} \mathrm{E}$ of Kumba, $28 \mathrm{~km}$ W of Loum., N4 ${ }^{\circ} 41^{\prime}$ E9³1', 16 Sept. 1972, Leeuwenberg, AJM 10334 (BR, MO, P, WAG, YA); culta, in greenhouse Wageningen, The Netherlands, No. 1972PT00634 (leg. Leeuwenberg 10334), Aug. 1983, Hort Bot Wageningen s.n. (WAG, WAGspirit); ibid., 19 July 1984, Setten, K van 845 (WAG, WAG-spirit); ibid., 17 Feb. 1992, Setten, K van 1061 (WAG); ibid., Veldhuizen, J van 1355 (WAG); ibid., 5 Aug. 1997, Veldhuizen, J van 1539 (WAG, WAG-spirit). - EquAToRIAL GuINEA, Bioko, Fernando Po, c. N3 ${ }^{\circ} 30^{\prime}$ E $8^{\circ} 42^{\prime}$, July 1860, Mann, G 8 A (K [K000321374]). - GABON, Woleu-Ntem, c. $75 \mathrm{~km} E$ of Chantier SEF of Leroy-Abanga, at the end of concession road, c. N0 ${ }^{\circ} 50^{\prime} \mathrm{E} 11^{\circ} 10^{\prime}, 10$ July 1985, Bos, JJ 10571 (LBV, WAG); culta, in greenhouse Wageningen, The Netherlands, No. 85PTGA220, leg. Bos. JJ 10570 [1]; ibid., 24 Jan. 1985, Bos, JJ 10828 (WAG). - UNKNOWN, Berggarten, Herrenhausen, sine loco, 21 Feb. 1905, Hort Bot Herrenhausen s.n. (K).

\section{Dracaena laxissima Engl. - Map 12}

Dracaena laxissima Engl. (1892) 478. — Type: Pogge 1462 (holo B (B_10_ 0160916)), Democratic Republic of the Congo, Mukenge, 18 Feb. 1882. Dracaena bequaertii De Wild. (1921) 37. - Type: Bequaert 6322 (holo BR (BR0000008808493)), Democratic Republic of the Congo, Mukule-Mokoto, 19 Dec. 1914, syn. nov.

Dracaena thomensis Dandy in sched.

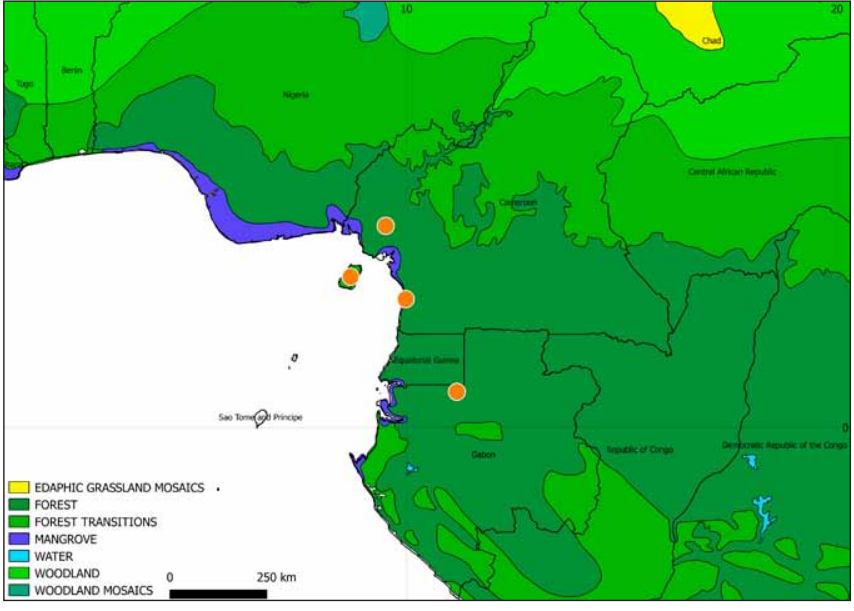

Map 11 Distribution of Dracaena haemanthoides Bos ex Damen.

Distribution - Nigeria, Cameroon, Equatorial Guinea, Sao Tome and Principe, Gabon, Central African Republic, Republic of the Congo, Democratic Republic of the Congo, Rwanda, Burundi, Sudan, Uganda, Kenya, Tanzania, Zambia, Malawi, Mozambique.

Notes - Dracaena bequaertii was described from a lianescent plant with a shorter inflorescence than the typical $D$. laxissima, but otherwise fits that species' morphology. From studying a large number of herbarium collections, it appears that the inflorescence length in $D$. laxissima can vary between 5 and $50 \mathrm{~cm}$, and hence we do not recognise $D$. bequaertii as a distinct taxon.

Dracaena thomensis was encountered as a name written on the identification slip mounted on the specimen Quintas 1, deposited in K (K000255924). The name does not seem to have been formally published.

\section{Dracaena laxissima Engl. forma aureilicia Wiland \&}

Q.Luke, forma nov. - Plate 4; Map 12

A form differing from the typical form of $D$. laxissima by distinctive, white cream or yellowish, irregularly undulating bands along transversal veins of the leaves. Flowers greenish white, usually with no pinkish taint, as in the typical form of D. laxissima. - Type: Lisowski, S 80127 (holo POZG 2 sheets), Democratic Republic of the Congo, Orientale, route Kisangani-Lubutu, km 189, près du village Mengwe, S0²6' E26¹3', 6 Dec. 1981

Etymology. The transversal bands on the leaves of this form reminds of a golden thread in a green fabric.

Distribution — Democratic Republic of the Congo, Tanzania.

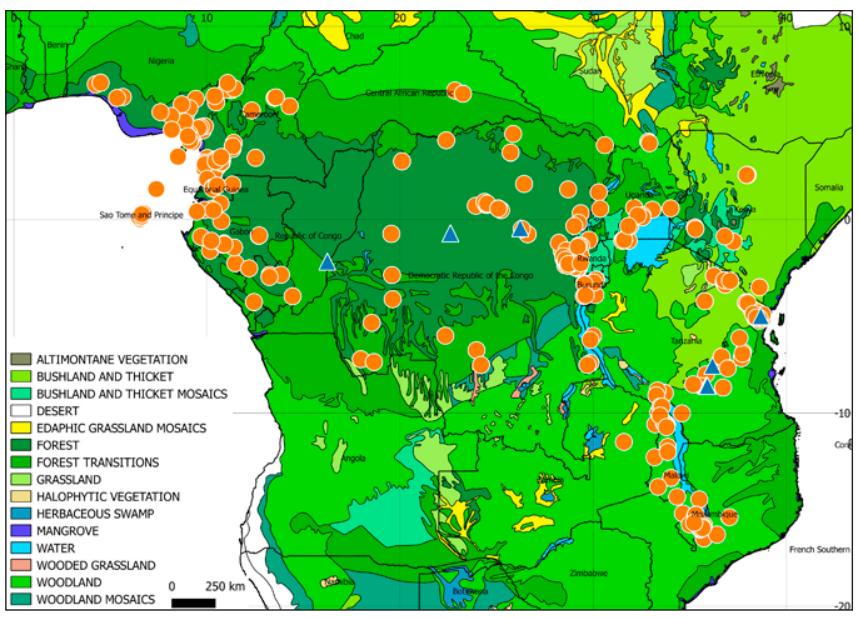

Map 12 Distribution of Dracaena laxissima Engl. forma laxissima (๑) and Dracaena laxissima Engl. forma aureilicia Wiland \& Q.Luke (A). 


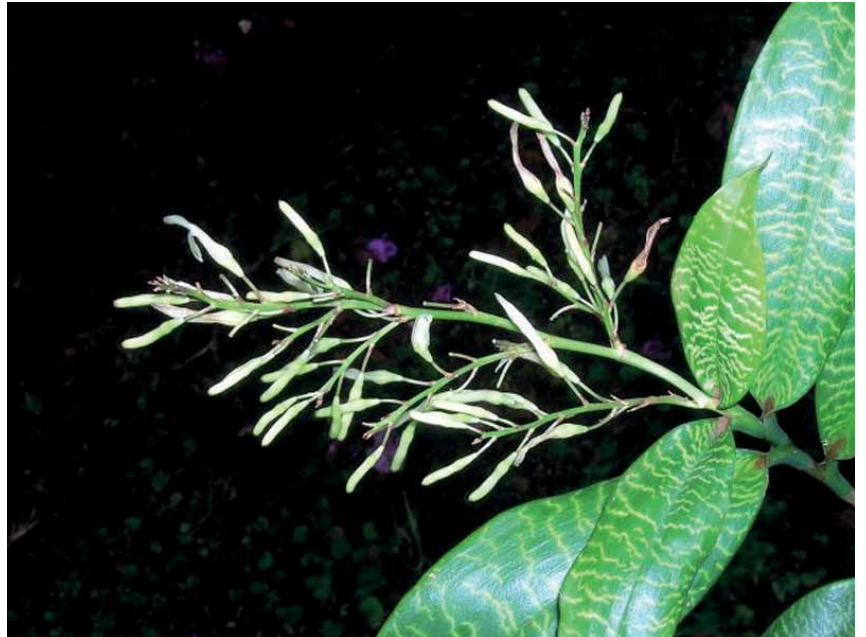

Plate 4 Dracaena laxissima Engl. forma aureilicia Wiland \& Q. Luke, habit and young inflorescence showing typical variegation, Luke s.n. - Photo: WRQ Luke.

Ecology - Primary, riverine and swamp forest; foodplant for Artitropa sp. (S. Collins, pers. comm.), at 300-1600 m altitude. Flowering: February, March.

Other specimens examined. Democratic Republic of the Congo, Bandundu, Mushie, Bomongo, c. S2¹0' E16¹4', Feb. 1951, Flamigni, A 10269 (BR, WAG); Equateur, Ikela, Yalikungu, c. S0 ${ }^{\circ} 42^{\prime}$ E22 $2^{\circ} 36^{\prime}, 28$ Nov. 1958, Evrard, CM 5258 (BR). - TANZANIA, Iringa, Kilolo District, Iyai village, Image Forest Reserve, Mountains Range, Selebu Mountain Base, Ihongole valley, S7 ${ }^{\circ} 33.4^{\prime}$ E3609.9', alt. 1510-1600 m, 2 Sept. 2011, Kayombo, CJ 6963 (TAN, WAG); Morogoro, Kilombero District, top end of Kihanzi Gorge, S8 ${ }^{\circ} 34^{\prime}$ E35 $35^{\circ} 51^{\prime}$, alt. 1000-1100 m, 17 Apr. 2008, Bidgood, GS 6462 (K, P, WAG); culta in Steve Collins' garden Nairobi, Kenya, ex Kihansi Gorge, c. S8³5149' E35505916', alt. 910 m, 5 Mar. 2010, Luke Q s.n. (WAG-photo); Tanga, Muheza District, Kwezitu public forest along path to peak between Mkalamo and Gonja subvillages, S4559.3' E38 $40.2^{\prime}$, alt. 825 m, 4 Aug. 2000, Mwangoka, MA 1594 (MO, $P O Z G)$.

\section{Dracaena mannii Baker - Map 13}

Dracaena mannii Baker (1874) 164. - Lectotype (designated here): Mann 2329 (lecto K (K000255908); isolecto A, B, K (K000255909, K000255910), P, WAG), Nigeria, River Old Calabar, 1863.

Dracaena tessmannii Engl. \& K.Krause (1910) 151. - Type: Tessmann 358 (holo B (B_10_0160913); iso B (B_10_0160914), WAG-fragment), Equatorial Guinea, Mabungo, 21 Apr. 1908, syn. nov.

Dracaena usambarensis Engl. var. Iongifolia De Wild. (1905) 43. — Lectotype (designated here): Laurent \& Laurent s.n. (lecto BR (BR0000008807427)), Democratic Republic of the Congo, Lisala, 7 Jan.1904

Distribution - Benin, Nigeria, Cameroon, Equatorial Guinea, Gabon, Central African Republic, Republic of the Congo, Democratic Republic of the Congo, Angola.

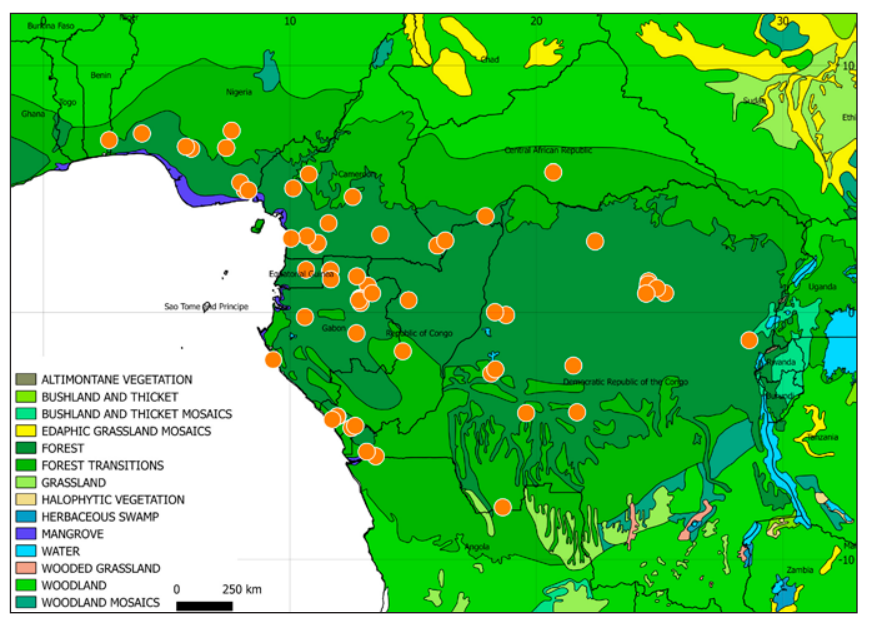

Map 13 Distribution of Dracaena mannii Baker.
Notes - The protologue of D. mannii mentions two collections: Mann 2329 and Thompson s.n.; Bos (1984) already selected Mann 2329 deposited at $\mathrm{K}$ as the lectotype for this name. However, this collection is composed of three sheets. Since Bos has clearly annotated sheet K000255908 as lectotype and the others as duplicates, we have herewith made his choice more explicit and limited it to a single sheet, in conformity to Art. 8.2 and 8.3 of the ICN (McNeill et al. 2012).

Dracaena tessmannii was described from a plant with the same inflorescence and leaf shape as D. mannii. In the protologue, Engler \& Krause (1910) compared D. tessmannii with $D$. fragrans only. We assume they probably did not see any material of $D$. mannii when describing this new species.

All four syntypes of $D$. usambarensis var. longifolia at BR are \pm similar in the sense that they are composed only of leaves mounted on a sheet. They were collected at different locations on different dates. The lectotype chosen represents the only specimen with a plant description written on the label. This description is most likely used as the basis for the description in the protologue.

15. Dracaena marina Bos ex Damen, sp. nov. - Fig. 3; Plate 5, 6; Map 14

Dracaena marina is similar to the East African Dracaena usambarensis Engl.; it is easily distinguished from that species by the oblanceolate to narrowly oblanceolate leaves, its bright red to yellow inflorescence axes, and the perianth lobes that are longer than the tube. In $D$. usambarensis the leaves are narrow elliptic, the inflorescence axes are green to orange and the perianth lobes are shorter than the tube. - Type: Breteler 14640 (holo WAG (WAG0047304); iso LBV (LBV0008874), WAG (WAG0047305), WAG-spirit (WAG0029799)), Gabon, Gamba region. c. S240' E1000', 11 Nov. 1998.

Dracaena sp., Keay et al. (1964) 439, based on Stanfield FHI47067 (not located), Lagos, Apapa.

Etymology. Bos already recognised this species as distinct and had provisionally named it $D$. marina, because it is often found close to the ocean. With this name, Bos also wanted to honour Ms Marina Wassink, the former secretary of the Plant Taxonomy Department at Wageningen University, The Netherlands, who had been a great help to him.

Shrub or large tree of up to $40 \mathrm{~m}$ high; trunk up to $60 \mathrm{~cm}$ diam, forming stilt roots when growing in inundated areas or mangroves; bark smooth to shallowly longitudinally fissured, grey, slash creamy white, not exuding resin; leaves densely set along the branches, tufted at the apex in older specimens, stem visible between the leaves. Leaves spirally arranged, sessile; lamina variable, oblanceolate and up to 30 by $9 \mathrm{~cm}$, but on fast growing shoots often narrowly oblanceolate and up to 60 by $8 \mathrm{~cm}$, coriaceous, dark dull green above, pale green with prominent midrib below, secondary veins inconspicuous, base gradually tapering, then abruptly expanding and clasping the stem for $1 / 2$ to $3 / 4$ of its circumference, apex acute to acuminate, mucro c. $3 \mathrm{~mm}$ long. Inflorescence terminal, erect, a much branched panicle, up to 75 by $55 \mathrm{~cm}$; peduncle smooth, flexible (like rubber), bright yellow to bright red; bracts supporting the branches triangular, up to 10 by $7 \mathrm{~mm}$ (distally decreasing in size), early caducous, coriaceous; flowers solitary or arranged in fascicles of up to c. 5 , each solitary flower or fascicle subtended by a small triangular, membranous, caducous bract with scarious margin, up to $2 \mathrm{~mm}$ long. Flower: pedicel bright orange, to 15 $\mathrm{mm}$ long, persistent basal part to $13 \mathrm{~mm}$ long, surrounded by early caducous scarious floral bracts of c. $1 \mathrm{~mm}$ long; perianth creamy white, 35-55 mm long, lobes 24-33 mm long; stamens inserted near the throat, up to $3 \mathrm{~mm}$ shorter than the lobes, filaments filiform, white, anthers c. $2.5 \mathrm{~mm}$ long, pale yellow; ovary ovoid, 3 by $2.5 \mathrm{~mm}$; style filiform, exserted for up to $3 \mathrm{~mm}$, white, stigma c. $0.5 \mathrm{~mm}$ diam. Fruits globose to depressed globose, up to 23 by $28 \mathrm{~mm}$, glossy, orange-brown to red, usually with 1 seed, receptacle swollen, up to 6 by 3 


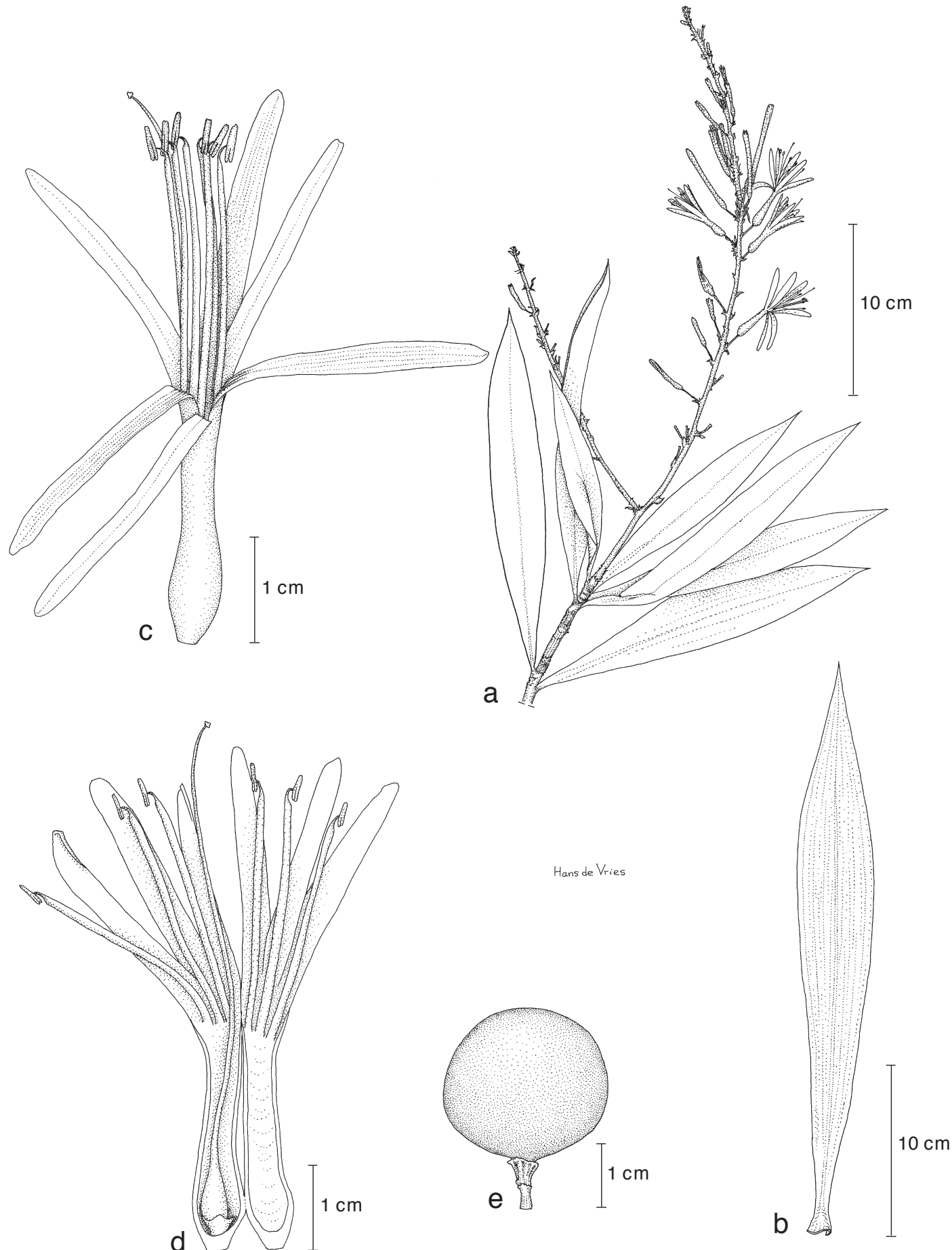

Fig. 3 Dracaena marina Bos ex Damen. a. Branch and inflorescence; b. leaf; c. flower; d. dissected flower; e. fruit (a, c-d: Breteler 14640; b: Damen 671; e: Louis, AM 4034). - Drawing by Hans de Vries.

mm wide, mesocarp orange. Seeds depressed globose, 17 by $22 \mathrm{~mm}$, shallowly bilobed, smooth, brown; endosperm slightly transparent white.

Distribution - Benin, Nigeria, Cameroon, Gabon, Republic of the Congo, Democratic Republic of the Congo, Angola.

Ecology - Primary and secondary forest, in swamp or mangrove vegetation, on sandy soil; at $0-200 \mathrm{~m}$ altitude. Flowering: January, March, June, August to November.

Uses - Fruits are eaten by rodents (fide Wieringa 5044).

Vernacular names - Alenokue (Pahouin de Libreville) (fide Fleury in Chevalier 33649); Mungonga (fide Vermoesen 1189).

Other specimens examined. AngoLA, Zaire, Lower Congo river, Santo Antonio do Zaire. c. S6 ${ }^{\circ} 08^{\prime}$ E12 ${ }^{\circ} 23^{\prime}, 14$ Nov. 1922, Gossweiler, J 8505 (K). BenIn, Ouémé, Adjarra, Adjarra-Anagodomè, N6³2.2' E2² 40.3', 8 Feb. 2000, Akoègninou, A 3090 (BENIN, BR, MO, WAG). - CAMEROON, South-West, au delà de la rivière Banan, sur piste de Tabo à Agborkem, C. N5 ${ }^{\circ} 46^{\prime} E 9^{\circ} 07^{\prime}$, 4 June 1975, Letouzey, R 13727 (K, P, WAG, YA). - Democratic Republic of THE Congo, Bas-Congo, Kinshasa, Lukula, Luki, vallée Lusona, c. S5 ${ }^{\circ} 38^{\prime}$ E1304', 1 June 1948, Donis, C 1787 (BR, WAG); Boma, environs de Malela, c. S55' E12 ${ }^{\circ} 37^{\prime}, 28$ Dec. 1918, Vermoesen, FMC 1241 (BR, K, P); ibid., 23 Dec. 1918, Vermoesen, FMC 1189 (BR). - GABON, Estuaire, Moka creek, E of Moudah River, N0³9' E9²8', alt. 5 m, 24 July 1985, Bos, JJ 10800 (WAG); Alenokue, environs de Libreville, c. N0²5' E9 ${ }^{\circ} 26^{\prime}$, May 1917, Fleury in Chevalier, AJB 33649 (LBV, P, WAG); Mondah ecotour forest, N0 ${ }^{\circ} 34.54^{\prime}$ E9 $20.09^{\prime}$, alt. 53 m, 17 Mar. 2015, Damen, THJ 671 (BG NL07-living plant, BR, LBV, WAG); Parc National de la Pongara, forêt c. $3 \mathrm{~km}$ au sud de la pointe Kenguéré, N0¹0.8' E9 $20.4^{\circ}$, alt. 25 m, 16 Jan. 2007, Dauby, GV 95 (BRLU, MO); Ekouk, piste du nouveau campement, S0¹0' E10¹5', 30 Sept. 1983, Floret, JJ 1576 (MO, P, WAG); Bord du Layon N 20 à 900 m de la route Cap Esterias, forêt de la Mondah, N0³4' E9²2', 3 Dec. 1970, Gavage, A 7 (BR, K, WAG); Mt Bouet, N0²6' E9²8', 9 Aug. 1898, Klaine, T-J 162a (P, WAG); environs de Libreville, c. N0²5', E9²7', 1896, Klaine, T-J 400bis (BR, FHO, IFAN, P); ibid., 20 Aug. 1902, Klaine, T-J 455a (P); 


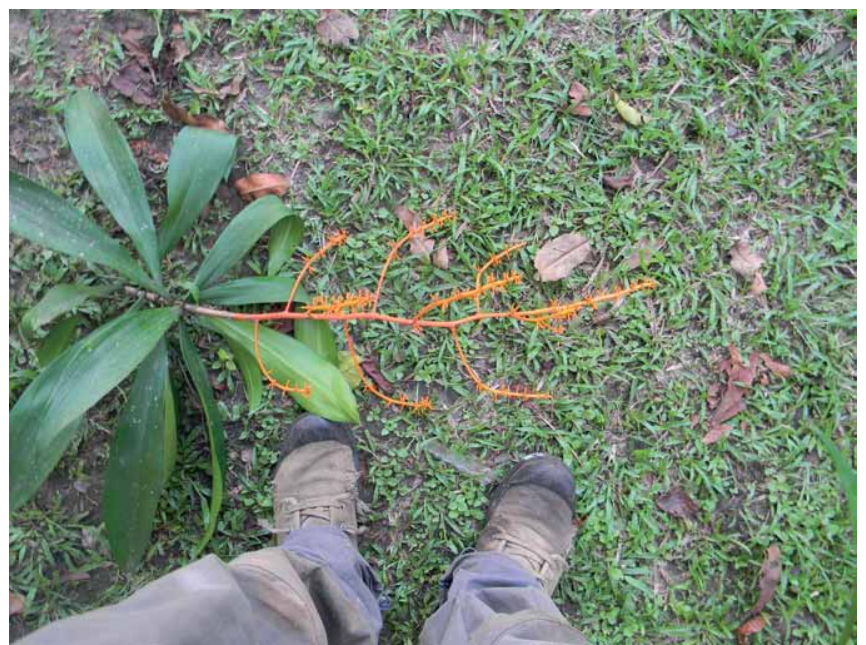

Plate 5 Dracaena marina Bos ex Damen, coloured old infructescence; Damen 671. — Photo: THJ Damen.

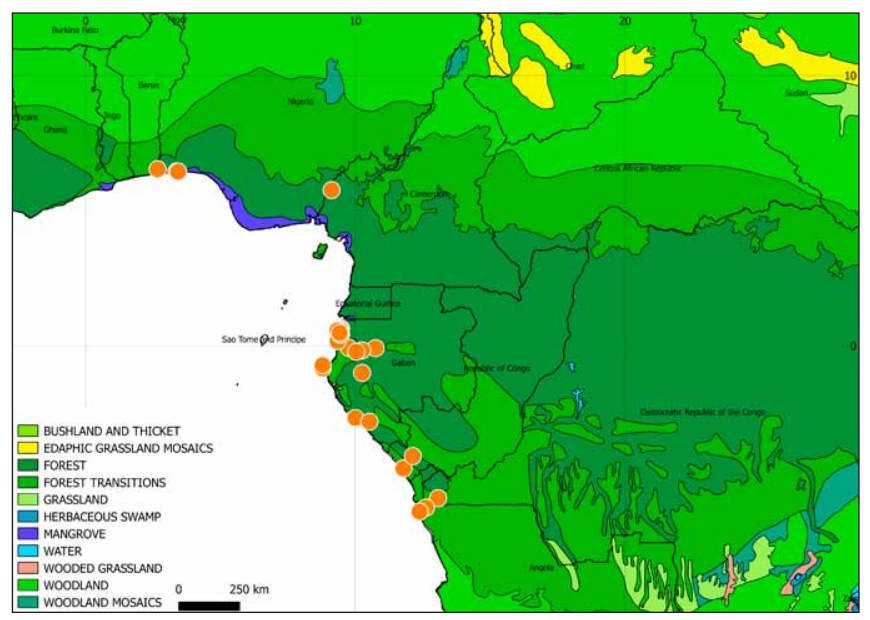

Map 14 Distribution of Dracaena marina Bos ex Damen.

Malibé-mangrove, N0³6' E9²6', 2 Oct. 1985, Louis, AM 1829 (LBV, WAG); bord Remboué, S004' E945', alt. 5 m, 19 Dec. 1990, Louis, AM 3282 (LBV, MO, WAG); au platform de forage, Remboué, S10¹3', E1002', 21 Jan. 1991, Louis, AM 3289 (LBV, MO, WAG); secondary forest, c. $15 \mathrm{~km}$ north of Libreville, N0³4' E9²1', 18 Mar. 1987, Reitsma, JM 3184 (LBV, MO, NY, WAG); Okala, north of Libreville, terrain de Montigny à Okala (Libreville), N0 ${ }^{\circ} 29^{\prime}$ E9²5', alt. 10 m, 12 Feb. 2014, Stévart, TOBEB 4792 (BRLU, L, LBV, MO, P, WAG); road from Libreville to Cape Esterias, c. N0 $31^{\prime}$ E9 $22^{\circ}$ ', alt. $20 \mathrm{~m}, 21$ Jan. 1993, Wilde, JJFE de 10885 (MO, WAG); Moyen-Ogooué, Missanga, 10-20 km N of Ndjolé, c. S005' E1045', 13 Nov. 1991, Breteler, FJ 10449 (LBV, MO, WAG); SW de Lambaréné, Lac Ezanga, c. S100' E10¹5', 29 May 1963, Hallé, N 2091 (P); Nyanga, forestry concession of Baker, $13 \mathrm{~km}$ NNE of Igotchi, S2 ${ }^{\circ} 48.07^{\prime}$ E10 $10^{\circ} 31.45^{\prime}$, alt. 200 m, 31 Oct. 2003, Wieringa, JJ 5044 (LBV, WAG); Ogooué-Maritime, Port Gentil, c. S043' E847', 11 Sept. 1968, Breteler, FJ s.n. (WAG-photo); Port Gentil, savane sur sable vers Tchengue, S050' E847', 23 June 1993, Louis, AM 4034 (LBV, WAG). - NigeriA, Lagos, Flora Austro-Nigritina, S Nigeria, Lagos (Ikoyi), c. N6 ${ }^{\circ} 7^{\prime}$ E3 ${ }^{\circ} 26^{\prime}, 26$ Apr. 1950, Bels, L 89 (U); Lagos, c. N6 ${ }^{\circ} 27^{\prime}$ E3 ${ }^{\circ} 23^{\prime}$, Apr. 1883, Moloney, CA 2 (K). - Republic of the Congo, Kouilou, Kouilou, Tchissanga (10 km de Bas-Kouilou), c. S4 ${ }^{\circ} 32^{\prime}$ E $11^{\circ} 47^{\prime}, 3$ Jan. 1991, Dowsett-Lemaire, F 1500 (BR, WAG); Sounda, c. S4 ${ }^{\circ} 05^{\prime}$ E12 ${ }^{\circ} 08^{\prime}, 7$ Feb. 1987, Foresta, $H$ de $1255(\mathrm{P})$.

Notes - Although we have not been able to trace Stanfield FHI47067, Keay's description of an unidentified arborescent Dracaena based on this specimen leaves little doubt that it is conspecific with $D$. marina. It also matches the location of other specimens of $D$. marina.

Dracaena marina can be confused with $D$. mannii since it keys out as such in Bos (1984, 1992), Mwachala \& Mbugua (2007) and La Croix (2010). It is easily distinguished from $D$. mannii by its flowers being less than half as long as those of $D$. mannii.

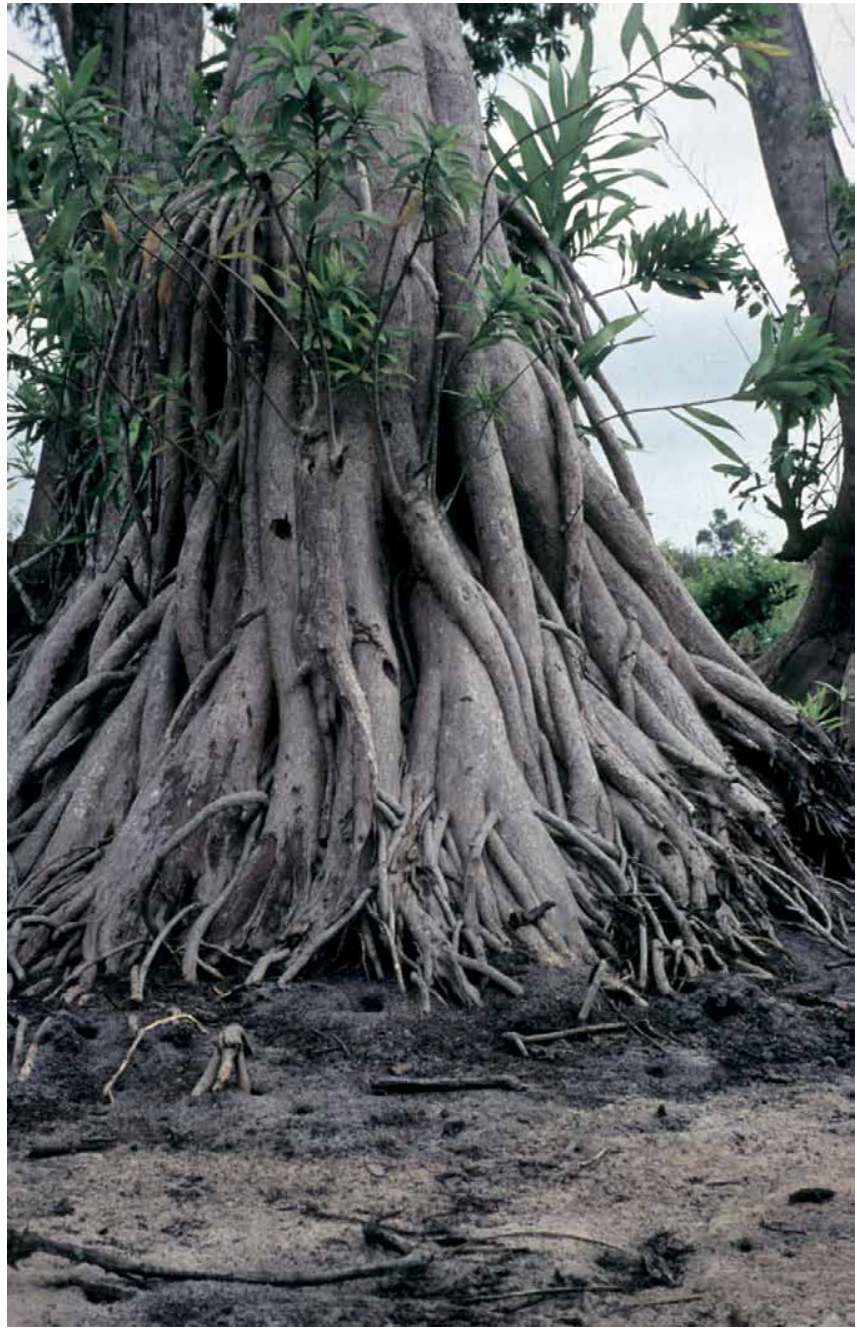

Plate 6 Dracaena marina Bos ex Damen, old specimen in inundated forest; Breteler \& Raalte s.n. - Photo: FJ Breteler.

\section{Dracaena nitens Welw. ex Baker - Map 15}

Dracaena nitens Welw. ex Baker (1878) 252. — Lectotype (designated here): Welwitsch 3743 (lecto BM [BM000911615]), Angola, Zenza do Golungo Alto, Sept. 1857.

Dracaena reflexa Lam. var. buchneri Engl. (1902) 96. — Syntypes: Büttner 531 (B十), Democratic Republic of the Congo, Dinga am Quango, Aug. 1885; Buchner $684(\mathrm{~B} \dagger)$, Democratic Republic of the Congo, Kehungula am Lovo und Mukinsh in Muata Yamvos-Reich, Nov. 1880, syn. nov.

Distribution - Cameroon, Equatorial Guinea, Gabon, Central African Republic, Republic of the Congo, Democratic Republic of the Congo, Angola.

Notes - Dracaena mannii, D. perrottetii and D. usambarensis are very similar to $D$. nitens and according to Bos (1984) even represent synonyms of the same species. However, $D$. nitens differs from the other species in having flowers 23-37 $\mathrm{mm}$ long and linear to narrowly elliptic leaves of up to only 1.5 $\mathrm{cm}$ wide, and is reinstated here.

The protologue of $D$. nitens does not cite any specimens, but it should be a plant collected by Welwitsch in Golungo Alto or Pungo Andongo, bearing flowers in September. The Welwitsch 3743 specimen deposited in BM carries a plant description in the hand of Baker. This description is obviously used as the basis for the description in the protologue of $D$. nitens. Also, on this sheet we find the annotation 'Lectotype' written by Bos. Therefore, we here follow Bos's suggestion and have chosen this specimen as the lectotype for $D$. nitens. Although there are several other Welwitsch collections (at COI, G, K, LISU, P and WAG) bearing the number 3743 , it is known that Welwitsch 


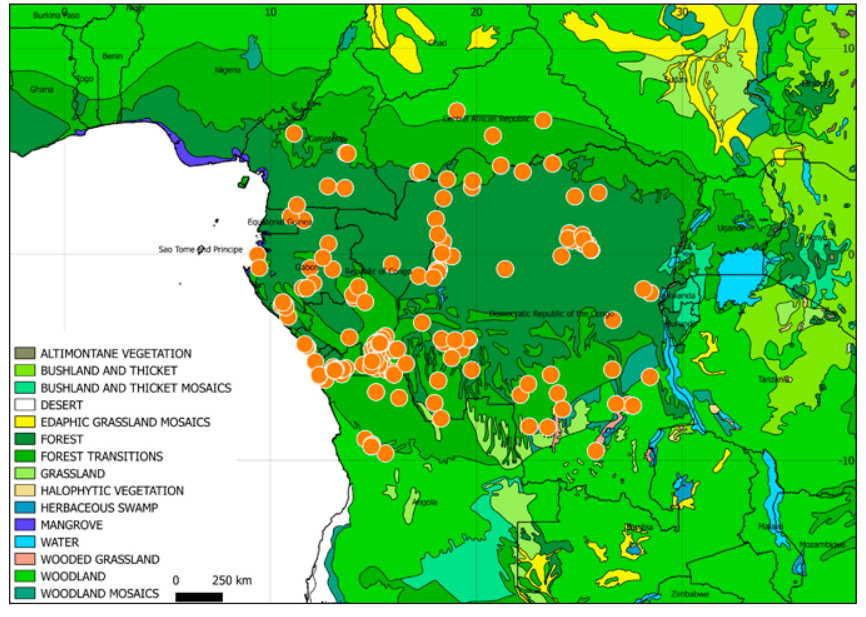

Map 15 Distribution of Dracaena nitens Welw. ex Baker.

regularly gave plants collected on different dates and localities the same number (Albuquerque et al. 2009). Since there is no indication that the other sheets represent the same collection (actually, some bear a different date) these are disregarded as isolectotype material.

Both syntypes of $D$. reflexa var. buchneri could not be located at $\mathrm{B}$, and are likely to have been destroyed. No duplicates could be found elsewhere, but it is still possible one may show up in, for example, LE or UC. Also, in the absence of any suitable material to serve as a neotype, we have for the moment refrained from designating one. The analysis in the protologue and the location fit within the range of $D$. nitens, which is why we consider this variety to belong to that species.

\section{Dracaena perrottetii Baker - Map 16}

Dracaena perrottetii Baker (1874) 165. - Lectotype (designated by Bos 1984): Perrottet 785 (lecto G [G00018458]; isolecto K, P (2 sheets), WAGspirit), Senegal, Casamance, 5 Apr. 1829.

Dracaena perrottetii Baker var. minor Baker (1875) 529. - Type: Heudelot s.n. (holo K [K000255907]; iso P [P02152538, P02152539]) (erroneously cited in Bos (1984) as Heudelot 2838), Guinea, Rio Nunez, 1838, syn. nov. Pleomele heudelotii N.E.Br. (1914) 278. - Type: as for D. perrottetii var. minor, syn. nov.

Distribution - Senegal, Gambia, Guinea Bissau, Guinea, Sierra Leone, Liberia, Ivory Coast, Ghana, Togo, Benin, Nigeria, Cameroon.

Notes - Dracaena nitens, D. mannii, and D. usambarensis are very similar to $D$. perrottetii and according to Bos (1984) are even synonyms of the same species. However, $D$. perrottetii

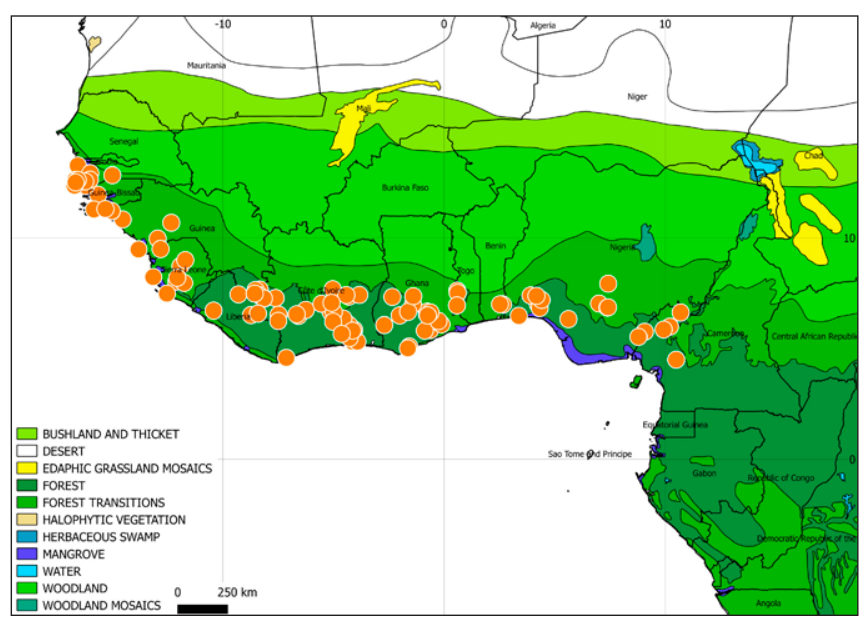

Map 16 Distribution of Dracaena perrottetii Baker. differs from the other species in having subfalcate leaves usually wider than $1.5 \mathrm{~cm}$, and is reinstated here.

Dracaena perrottetii var. minor was described from a plant with smaller leaves and a simple inflorescence. Studied material shows that leaves in $D$. perrottetii are polymorphic and that both branched and unbranched inflorescences occur even on the same plant. Therefore we do not recognise such a form as a distinct taxon.

Pleomele heudelotii was described based on the same material as $D$. perrottetii var. minor.

\section{Dracaena sanderiana Sander ex Mast. - Plate 7; Map 17}

Dracaena sanderiana Sander ex Mast. (4 June 1892) 731. - Neotype (designated here): Gard. Chron., ser. 3, 13: 445 (1893), f. 65 (iconotype). Dracaena poggei Engl. (10 June 1892) 478. — Lectotype (designated here): Pogge 1434 (lecto B (B_10_0160840)), Democratic Republic of the Congo, am Lomami, 30 May 1882, syn. nov.

Dracaena vanderystii De Wild. (1915) 7. - Lectotype (designated here): Vanderyst 2003 (lecto BR (BR0000008807540)), Democratic Republic of the Congo, Lazaret S. Jules, Wombali, Aug. 1913, syn. nov.

Distribution - Cameroon, Gabon, Central African Republic, Republic of the Congo, Democratic Republic of the Congo, Angola.

Notes - Dracaena sanderiana was first exhibited by Hort. Sander in Earl's Court (1892), and published the same year with a description, but without illustration. Original material of the plant exhibited has not been traced and has probably not been conserved. One year later, $D$. sanderiana was exhibited by Hort. Sander in Ghent and an illustration was published in Gard. Chron., ser. 3, vol. 13 (1893). This illustration most likely represents the same plant as originally exhibited in 1892 and is hence chosen here as the neotype.

Dracaena sanderiana is an important indoor ornamental plant (Morsy \& Elshahawy 2016) also sold under the name $D$. braunii and 'Lucky Bamboo' (Aslam et al. 2013). According to The World

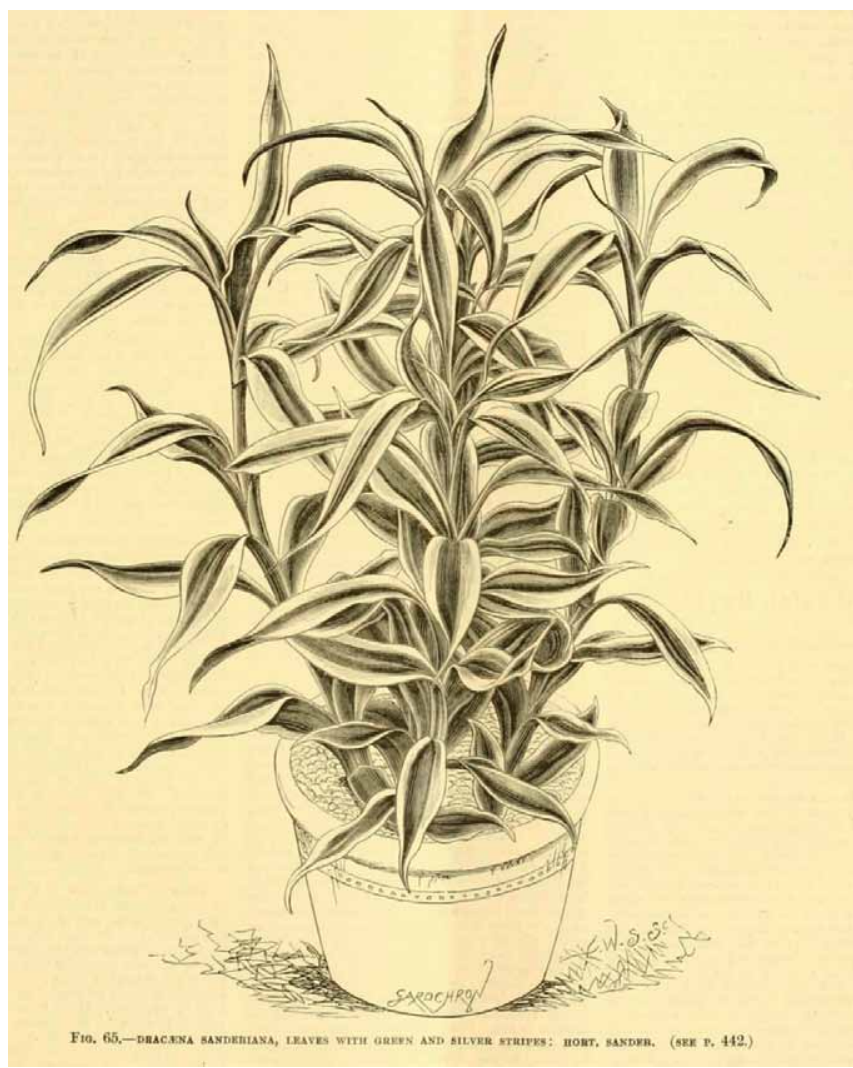

Plate 7 Iconotype Dracaena sanderiana Sander ex Mast. in Gard. Chron., ser. 3, 13: 445 (1893), f. 65. 


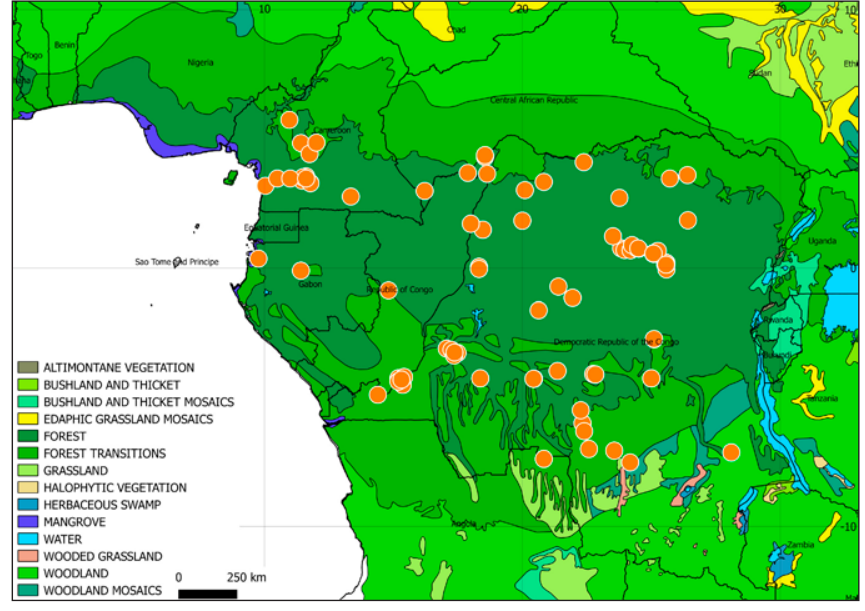

Map 17 Distribution of Dracaena sanderiana Sander ex Mast.

Checklist of Asparagaceae (Govaerts et al. 2017), D. sanderiana is a synonym of $D$. braunii, but unfortunately no reference is given to the origin of this information. We have not found any revision or flora that underlines this statement, although Baker (1898) stated that $D$. sanderiana is similar to $D$. braunii, he surely did not regard them as conspecific.

The flowers of $D$. sanderiana are 5 times longer than those of $D$. braunii, while the leaf base is not congested as in $D$. braunii. Here we treat them as distinct taxa.

The inflorescence of $D$. poggei fits well within the range of $D$. sanderiana and the type material represents nothing more than a non-variegated form of $D$. sanderiana. Reason why we do not recognise this form as a distinct taxon. Luckily, the publication of $D$. sanderiana predates that of $D$. poggei only by a few days, so that the first can be maintained for this important ornamental.

Dracaena vanderystii was described from a plant with comparatively narrow leaves. The inflorescence fits well within the range of $D$. sanderiana and observations in herbaria, in the field and on cultivated material all show that leaf shape within Dracaena is highly variable. Therefore, we do not recognise this form as a distinct taxon. In his unpublished PhD thesis, Mwachala (2005) designated the same lectotype for $D$. vanderystii, but stated it was to be found in $\mathrm{P}$. This is probably a typo which is corrected here.

\section{Dracaena steudneri Engl. - Map 18}

Dracaena steudneri Engl. (1895) 143. - Type: Steudner 477 (holo B; iso BR-photo (BR0000009888289), S (S06-4677)), Ethiopia, Dschibba, 30 Nov. 1861.

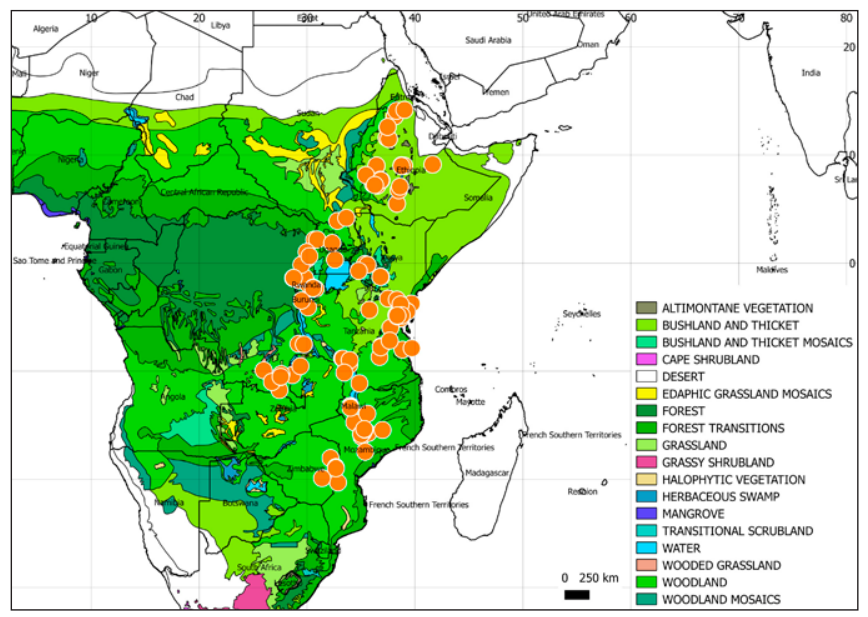

Map 18 Distribution of Dracaena steudneri Engl.
Distribution - Democratic Republic of the Congo, Rwanda, Burundi, Sudan, Ethiopia, Uganda, Kenya, Tanzania, Zambia, Malawi, Mozambique, Zimbabwe.

Note - The only material cited in the protologue is Steudner 477 from Dschibba, Gondar. Both Bos \& Teketay (1997) and Mwachala \& Mbugua (2007) cited the holotype as being destroyed in B. However, we found this specimen filed under Dracaena deisteliana Engl. in the herbarium in Berlin.

\section{Dracaena tholloniana Hua - Map 19}

Dracaena tholloniana Hua (1897) 662. - Type: Thollon 91 (holo P (P00442286); iso K-fragment \& drawing (K000255934), P (P00442285)), Gabon, Ogooué, N'Djolé, Jan. 1895.

Dracaena longipetiolata Mwachala \& Eb.Fisch. (2013) 442. — Type: Hallé \& Villiers 5362 (holo P [P02058236]), Gabon, Monts de Cristal, 12 km SW de Kinguélé, 18 Feb. 1966, syn. nov.

Dracaena monostachya Baker var. angolensis Baker (1898) 447. — Lectotype (designated by Bos 1984): Welwitsch 3745 (lecto BM [BM000911609]), Angola, Golungo Alto, Apr. 1856, syn. nov.

Distribution - Cameroon, Gabon, Republic of the Congo, Democratic Republic of the Congo, Angola.

Notes - Dracaena tholloniana is very similar to $D$. aubryana Brongn. ex É.Morren and are synonyms according to Bos (1984). Dracaena tholloniana is reinstated here, because it differs from $D$. aubryana in having flowers of only $8-13 \mathrm{~mm}$ long, subtended by $0.5-1 \mathrm{~mm}$ long bracts. Dracaena aubryana has flowers $23-38 \mathrm{~mm}$ long, with bracts of 1-1.5 mm long.

The protologue of $D$. tholloniana cites Thollon 31 as the type and states 'Ndjolé, sur le haut Ogooué, sous-bois, fl. Janvier 1895'. However, at P, Thollon 31 represents an Asteraceae (Eclipta prostrata (L.) L.) with a different date and location. Both Bos (1992) and Mwachala \& Mbugua (2007) cite Thollon 91 as the holotype for $D$. tholloniana but give no reason for this change in number. They probably, as we, assume it was a printing error. There are two duplicates of Thollon 91 at P (P00442286, P00442285), the specimen with barcode P00442286 matches the locality data and collecting date mentioned in the protologue and is annotated 'Dracaena tholloniana Hua' in Hua's handwriting.

Dracaena longipetiolata was described from a fruiting specimen with a long petiole. However, such long petioles are also found in specimens otherwise perfectly fitting within $D$. tholloniana, while intermediates also exist. Furthermore, the infructescence also fits within the range of $D$. tholloniana. Therefore, we do not recognise this form as a distinct taxon.

According to Bos (1984), Dracaena monostachya var. angolensis is synonym of $D$. aubryana s.lat. It was described from

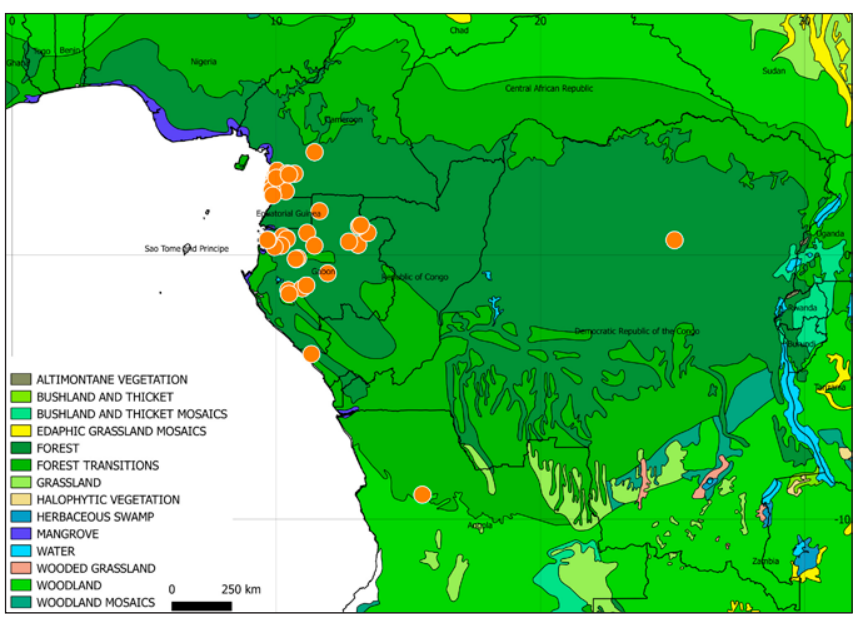

Map 19 Distribution of Dracaena tholloniana Hua 
a plant with a short peduncle and leaves with a rounded base and long petiole. These characters fit those of $D$. tholloniana, as does the lectotype chosen earlier by Bos.

\section{Dracaena usambarensis Engl. - Map 20}

Dracaena usambarensis Engl. (1895) 144. - Neotype (designated here): Volkens 65 (neo K-photo; isoneo BR-photo (BR0000021770135)), Tanzania, zw. Magali und dem Sigi, 24 Jan. 1893.

Dracaena gazensis Rendle (1911) 214. — Lectotype (designated here): Swynnerton 80 (lecto BM (BM000911614)), Zimbabwe, near Chirinda, 10 Oct. 1905, syn. nov.

Dracaena pseudoreflexa Mildbr. (in Mildbraed \& Perkins 1910) 63. — Lectotype (designated here): Wiss. Ergebn. Deut. Zentr.-Afr. Exped., Bot. (1907-1908) Taf. V, G-K (iconotype), syn. nov.

Dracaena brachythyrsa Peter in sched.

Dracaena usambarensis Engl. var. angustifolia Peter in sched.

Distribution - Democratic Republic of the Congo, Burundi, Kenya, Tanzania, Zambia, Malawi, Mozambique, Zimbabwe, South Africa.

Notes - Dracaena nitens, D. mannii, and D. perrottetii are very similar to $D$. usambarensis and according to Bos (1984) are synonyms of the same species. However, D. usambarensis is easily distinguished from the others by its large flowers of $40-55 \mathrm{~mm}$ long and is reinstated here.

Three syntypes of $D$. usambarensis are mentioned in the protologue: one collected at Quilimane (probably a Stuhlmann collection), Volkens 65 and Volkens 1938. We could not find this material in B and assume it was destroyed during the WWII bombing of the Berlin-Dahlem herbarium. The only material we could trace was found in $\mathrm{K}$ and $\mathrm{BR}$ and represent photos of the herbarium sheets Volkens 65 and Volkens 1938. We agree with Mildbraed (Mildbraed \& Perkins 1910) that Volkens 1938 belongs to $D$. afromontana Mildbr. and should be excluded. The photos of Volkens 65 match the description in the protologue and has been of great help in fixing the application of the name $D$. usambarensis. The photo in $\mathrm{K}$ is bigger and clearer than that in BR. Therefore, we have chosen the photo of Volkens 65 in $\mathrm{K}$ as the neotype of $D$. usambarensis.

Dracaena brachythyrsa is an unpublished name written on the label mounted on Peter 13906 deposited in B (B_10_0184055) and WAG (WAG.1154506).

The protologue of $D$. gazensis cites two syntypes with different locality data and collecting date, but with one collection number Swynnerton 80 and so a lectotype has to be assigned. Bos recognised this and annotated the BM specimen BM000911614 as lectotype but never formalized his choice. We agree with Bos that the BM specimen with both leaves and an inflorescence is most suited to serve as the lectotype. The other duplicate in $\mathrm{BM}$, with different date, and the specimens in $\mathrm{Z}$ and $\mathrm{K}$ that carry

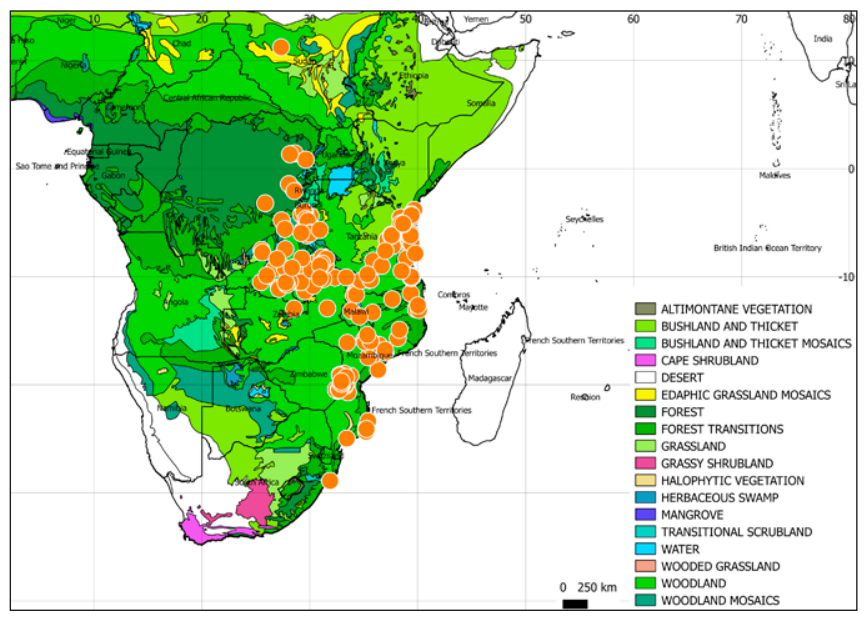

Map 20 Distribution of Dracaena usambarensis Engl. a different number, Swynnerton 80a, are disregarded. We also disregard the specimen Swynnerton $80 \mathrm{~b}$ from SRGH mentioned in Flora Zambesiaca as the holotype for $D$. gazensis (La Croix 2010), although we did not see material of this specimen.

Dracaena gazensis was described from a plant with the same inflorescence type, flower length and leaf shape as $D$. usambarensis. In the protologue, Rendle only compared $D$. gazensis with $D$. deremensis Engl.; he probably had not seen any material of $D$. usambarensis when describing his new species.

The protologue of $D$. pseudoreflexa cites two syntypes, Mildbraed 2813 and Mildbraed 2175. Both specimens are probably lost at B during WWII and we could only trace photos of Mildbraed 2813 in $\mathrm{K}$ and $\mathrm{BR}$. The drawing in the protologue is the only original material left and has enough detail to fix the application of this name; therefore we have chosen this drawing as a lectotype for $D$. pseudoreflexa.

Mwachala \& Mbugua (2007) cites a specimen Mildbraed 2813 deposited in $B$ as the holotype of $D$. pseudoreflexa, hence ignoring the syntype Mildbraed 2175. We have not been able to trace Mildbraed 2813 in B.

Dracaena pseudoreflexa was described from a plant with smaller leaves than the typical $D$. usambarensis. Leaf shape within $D$. usambarensis is highly variable and intermediates also exist (Damen, pers. obs.). We do not recognise this form as a distinct taxon. Mildbraed also mentioned that the tube length equals the lobes in the flower of $D$. usambarensis compared to the lobes being shorter than the tube in $D$. pseudoreflexa. The protologue of $D$. usambarensis has no information about the length of the lobes and we only found specimens with lobes shorter than the tube.

Dracaena usambarensis var. angustifolia is an unpublished name written on the label mounted on Peter 18536 deposited in B, BR [BR0000025334135] and WAG [WAG.1154504] [WAG.1154505].

\section{Dracaena viridiflora Engl. \& K.Krause - Map 21}

Dracaena viridiflora Engl. \& K.Krause (1910) 153. - Type: Zenker 3223 (holo B (B_10_0160837); iso BM, BR, G, K, MICH, WU), Cameroon, Bipindihof, July 1904.

Dracaena letestui Pellegr. (1930) 571. - Type: Le Testu 1376 (holo P (P00442292); iso BR, P (2 sheets) (P00442291, P00442290), WAG), Gabon, Boumé-Boumé, 28 Aug. 1908, syn. nov.

Dracaena mildbraedii K.Krause (1914) 447. - Type: Mildbraed 4976 (holo B (B_10_0160841); iso HBG (HBG-513964)), Cameroon, Bezirk Molundu, zwischen Jukaduma (Posten Plehn) und Assobam, 14³6'-14¹0'Ö.L. $3^{\circ} 24$ 'N.B., 17 Apr.1911, syn. nov.

Dracaena ledermannii Engl. \& K.Krause (1910) 152. — Neotype (designated here): Ledermann 6119 (neo B (B 10 0715949)), Cameroon, zwischen Boëck und Bare, 14 Nov. 1909, syn. nov.

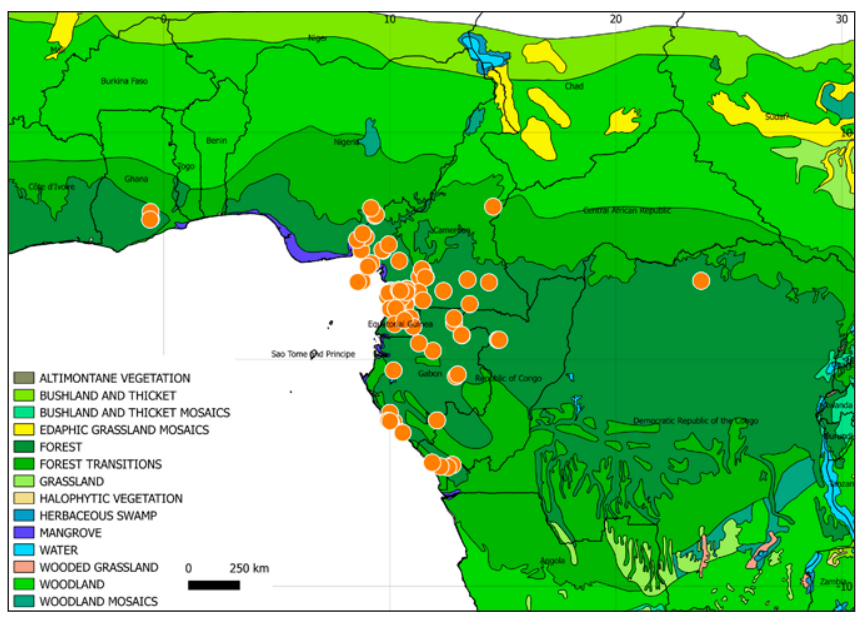

Map 21 Distribution of Dracaena viridiflora Engl. \& K.Krause. 
Distribution - Ghana, Nigeria, Cameroon, Equatorial Guinea, Gabon, Republic of the Congo, Democratic Republic of the Congo, Angola (Cabinda).

Notes - Both $D$. letestui and D. mildbraedii were described from plants with long linear leaves. From observations in the herbarium and during fieldwork, we have observed leaves of $D$. viridiflora to be extremely variable even on the same plant. Therefore, we do not recognise these forms as distinct taxa.

The type specimen of $D$. ledermannii, Ledermann 1483, the only specimen cited in the protologue, was probably lost at B during WWII. However, B also holds the specimen Ledermann 6119, which is annotated by Krause (S. Bollendorff \& P. Hiepko, pers. comm.) as $D$. ledermannii and fits the description provided in the protologue. We have identified it as belonging to $D$. viridiflora and chosen that specimen as the neotype for $D$. ledermannii.
23. Dracaena wakaensis Damen \& Quiroz, sp. nov. — Fig. 4; Plate 8; Map 22

Dracaena wakaensis is very similar to Dracaena phanerophlebia Baker and $D$. phrynioides. The inflorescence is less densely capitate, while the seeds in $D$. wakaensis are regularly ellipsoid and not lobed as those of $D$. phanerophlebia, nor horned as in D. phrynioides. When sterile, it differs from both in its shorter stem and smaller leaves. It resembles Dracaena praetermissa Bos from West Africa and has the same raceme shape, but the fruits of the latter are horned, and the peduncle is scabrid. - Type: Quiroz-Villarreal et al. 1782 (holo WAG (WAG.1924698); iso LBV), Gabon, Ngounié Prov. Département de Tsamba-Magotsi, District d'lkobey, Tranquille, S1 ${ }^{\circ} 03.33^{\prime}$ E11 $04.15^{\prime}$, alt. $751 \mathrm{~m}, 11$ Oct. 2012.

Etymology. The type was collected by Ms DK (Diana) Quiroz-Villarreal, at the edge of Parc National de Waka.

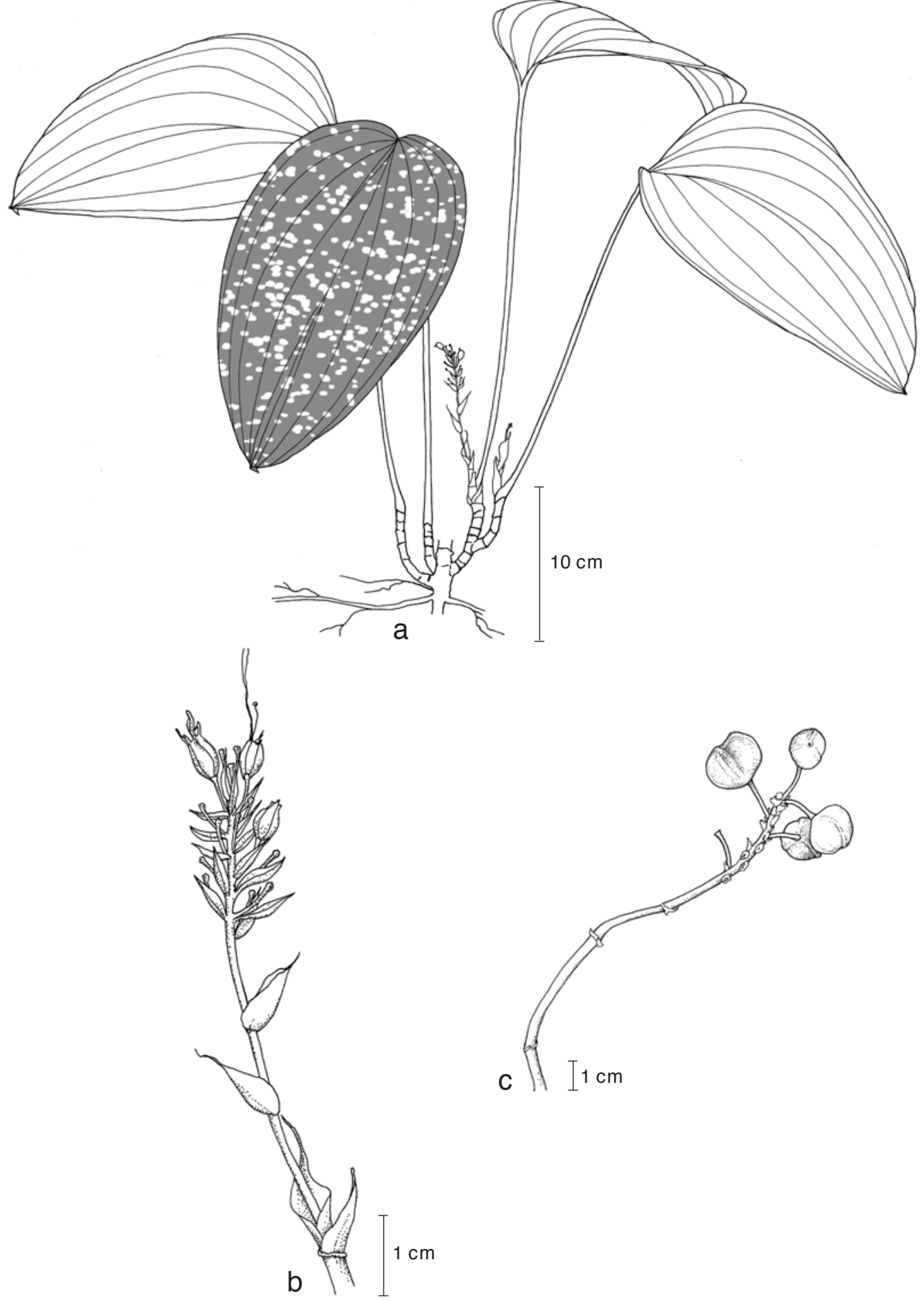

Fig. 4 Dracaena wakaensis Damen \& Quiroz. a. Habit; b. old inflorescence; c. flower; d. infructescence (a-b: Quiroz-Villarreal 1782; c: Louis, AM 2749). — Drawing by Kinga Berdysz. 


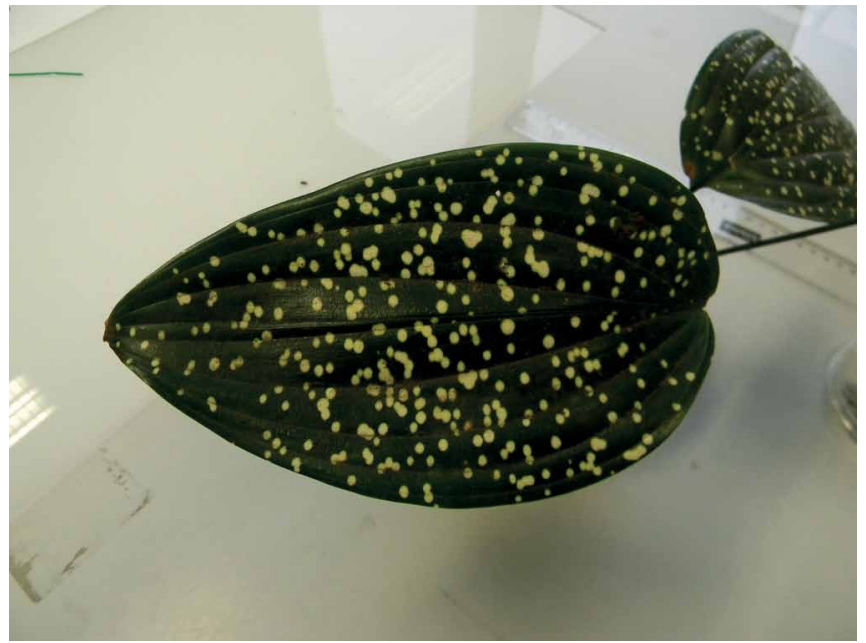

Plate 8 Dracaena wakaensis Damen \& Quiroz, showing leaf variegation; Damen 610. — Photo: THJ Damen.

Subshrub of up to c. $70 \mathrm{~cm}$ high, single-stemmed; stem usually unbranched, prostrate, to c. $5 \mathrm{~cm}$ high. Leaves up to 4 , in a rosette; pseudopetiole erect, slender, up to $52 \mathrm{~cm}$ long, terete, dark green, margin involute, abruptly extended into a short c. $1 \mathrm{~cm}$ long dark green to violet sheathing base, clasping the stem for more than its circumference; lamina ovate to broadly ovate, to 23 by $11 \mathrm{~cm}$, coriaceous, plicate, above glossy and uniformly dark green, below paler green, both surfaces variegated with transversely orientated greenish yellow to white round to oval dots, midrib inconspicuous, with up to c. 8 parallel nerves impressed above and prominent below, remaining nerves and venation inconspicuous, but conspicuous in herbarium specimens, base rounded, leaf tip declinate, broadly cuspidate, mucro c. $4 \mathrm{~mm}$ long. Inflorescence terminal, erect; peduncle smooth, c. $7 \mathrm{~cm}$ long; raceme c. $3 \mathrm{~cm}$ long; bracts up to 6 , early caducous, broadly triangular to cymbiform, 10 by $8 \mathrm{~mm}$, with aristate tip of up to $6 \mathrm{~mm}$ long, scarious, distally decreasing in size, sheathing at the base of the inflorescence to amplexicaul at its apex. Flower: pedicel up to $5.5 \mathrm{~mm}$ long, articulated near the apex; old dried flower $20 \mathrm{~mm}$ long, colour unknown, tube $6 \mathrm{~mm}$ long; filaments and anthers not seen; ovary ovoid, up to 4 by $2 \mathrm{~mm}$, style not seen. Fruits depressed globose, up to 15 by $20 \mathrm{~mm}$, shallowly 1-3-lobed, bright orange-red. Seeds ellipsoid, c. 7.5 by $5 \mathrm{~mm}$, with a smooth testa.

Distribution - Endemic to Gabon, only known from the Ngounié province.

Ecology - Growing in old secondary forest and on relatively dry forested slope near waterfall; at 700-950 m altitude. Occasionally forming a population covering several square meters.

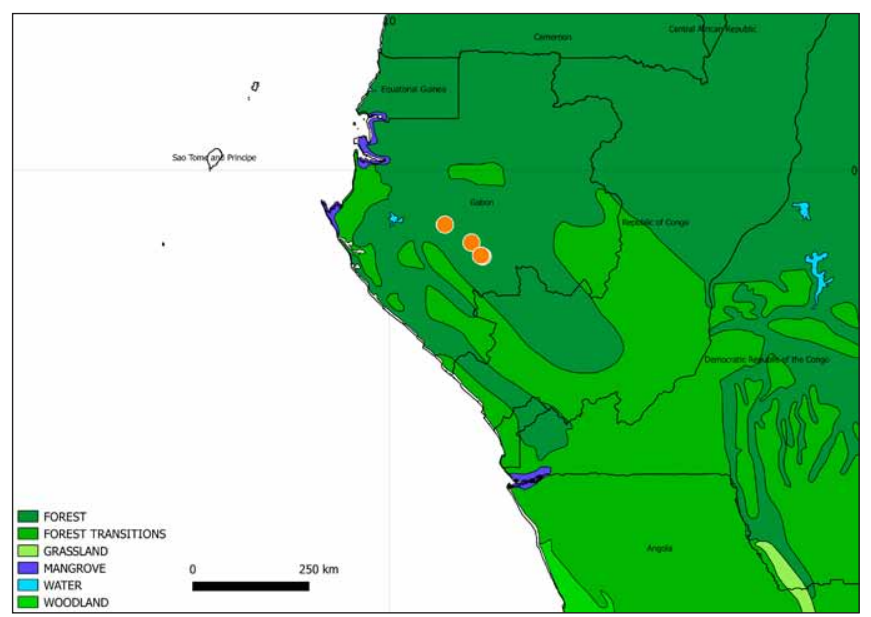

Map 22 Distribution of Dracaena wakaensis Damen \& Quiroz.
Flowering period unknown, but old inflorescence in September; fruiting in February.

Uses - Numerous bunches planted at 1 by $1 \mathrm{~m}$ by village women 'pour faire faro' (fide Hallé \& Cours Darne 5982); the most important plant of Boo women initiation rites (fide QuirozVillarreal et al. 1782).

Vernacular name - Endo (Babongo) (fide Quiroz-Villarreal et al. 1782).

Other specimens examined. GABON, Ngounié, piste de Massima à Moum-

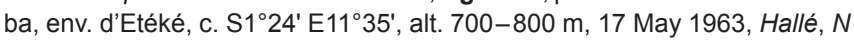
$5982(\mathrm{P})$; route Mimongo-Mbigou à $5 \mathrm{~km}$ du village lbaga vers Mbigou, vers montagne Ngangilè, S140' E1148', alt. 950 m, 13 Feb. 1988, Louis, AM 2749 (LBV, WAG); missionary station at Mouyanama, c. $15 \mathrm{~km}$ on the road Mimongo - Mbigou ( $60 \mathrm{~km}$ along the road from Mbigou), waterfall at c. 45 min. walking distance above the mission compound, c. S1 $1^{\circ} 39^{\prime} \mathrm{E} 11^{\circ} 46^{\prime}$, alt. 700 m, 9 Feb. 1983, Wilde (WALK-B), JJFE de 481 (WAG); culta in 'greenhouse' WAG (leg. Quiroz-Villarreal, DK, 1782, 11 Oct. 2012, département

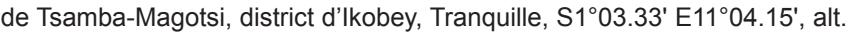
751 m), Nov. 2012, Damen, THJ 610 (WAG).

\section{Dracaena waltersiae Damen, sp. nov. - Plate 9, 10; Map} 23

Dracaena waltersiae is similar to $D$. laxissima, but it differs from that species in having petioles of only $2-3 \mathrm{~mm}$ long, a racemose inflorescence, flowers of $27-28 \mathrm{~mm}$ long with pedicel of only $6-9 \mathrm{~mm}$. In $D$. laxissima the petiole is $5-12 \mathrm{~mm}$, the inflorescence is paniculate, flowers are $16-20 \mathrm{~mm}$ long and have a slender pedicel of 11-21 mm. - Type: Walters \& Niangadouma 1271 (holo MO; iso LBV (LBV0002600), WAG (WAG0102272)), Gabon, Haut-Ogooué Prov., Plateaux Batéké National Park, Mpassa River drainage, Kalahari Sands, Projet Protection des Gorilles, 'Okeli Forest' trail M, S2 $08^{\circ}$ E14 $04^{\prime}$, alt. 420 m, 3 Mar. 2003

Etymology. Dracaena waltersiae honours Mrs Gretchen Walters who has collected the type and brought the plant to my attention. With her work, notably that on the Plateaux Batéké, she has made a substantial contribution to our knowledge of the flora of Gabon.

Lianescent shrub or tree of up to $10 \mathrm{~m}$ high; bark grey and slightly longitudinally fissured, without resin; branches with internodes of $(0.4-) 1.5-3(-4) \mathrm{cm}$. Leaves evenly distributed along the branches, distichously arranged; pseudopetiole c. 2-3 mm long, distinctly darker than the lamina, scariously winged, its base widened and clasping the stem for $0.5-0.7$ times its circumference; lamina subfalcate, elliptic to oblanceolate, up to 14 by $3 \mathrm{~cm}$, apex acute to acuminate, mucro 1 $\mathrm{mm}$ long, base attenuate, thinly coriaceous, midrib impressed above, prominent beneath, secondary nerves not evident above, prominent beneath. Inflorescence terminal or subaxillary, racemose, to c. $30 \mathrm{~cm}$ long, occasionally with a few branches; peduncle smooth, fluorescent orange, with fascicles of up to c. 4 flowers, each fascicle subtended by a small triangular, scarious, caducous, brown bract, of up to $4 \mathrm{~mm}$ long. Flower:

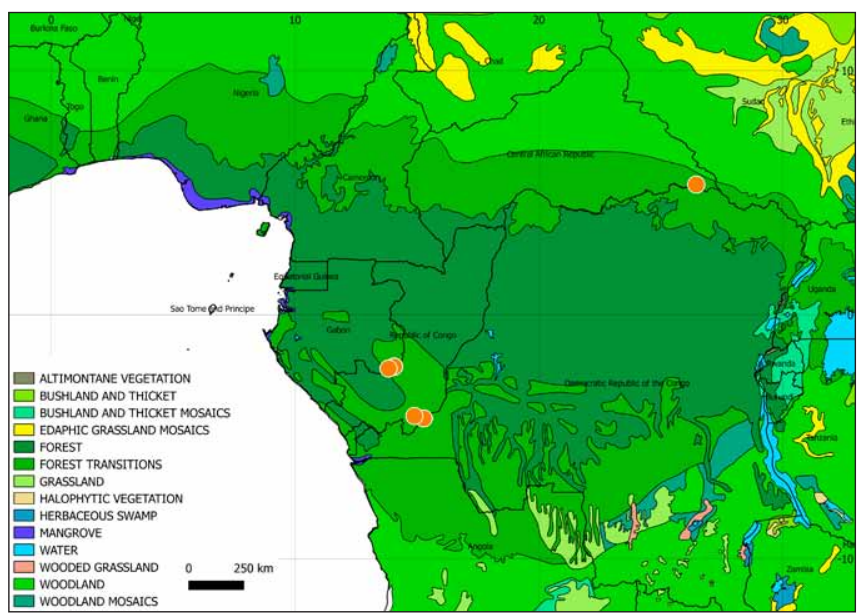

Map 23 Distribution of Dracaena waltersiae Damen. 


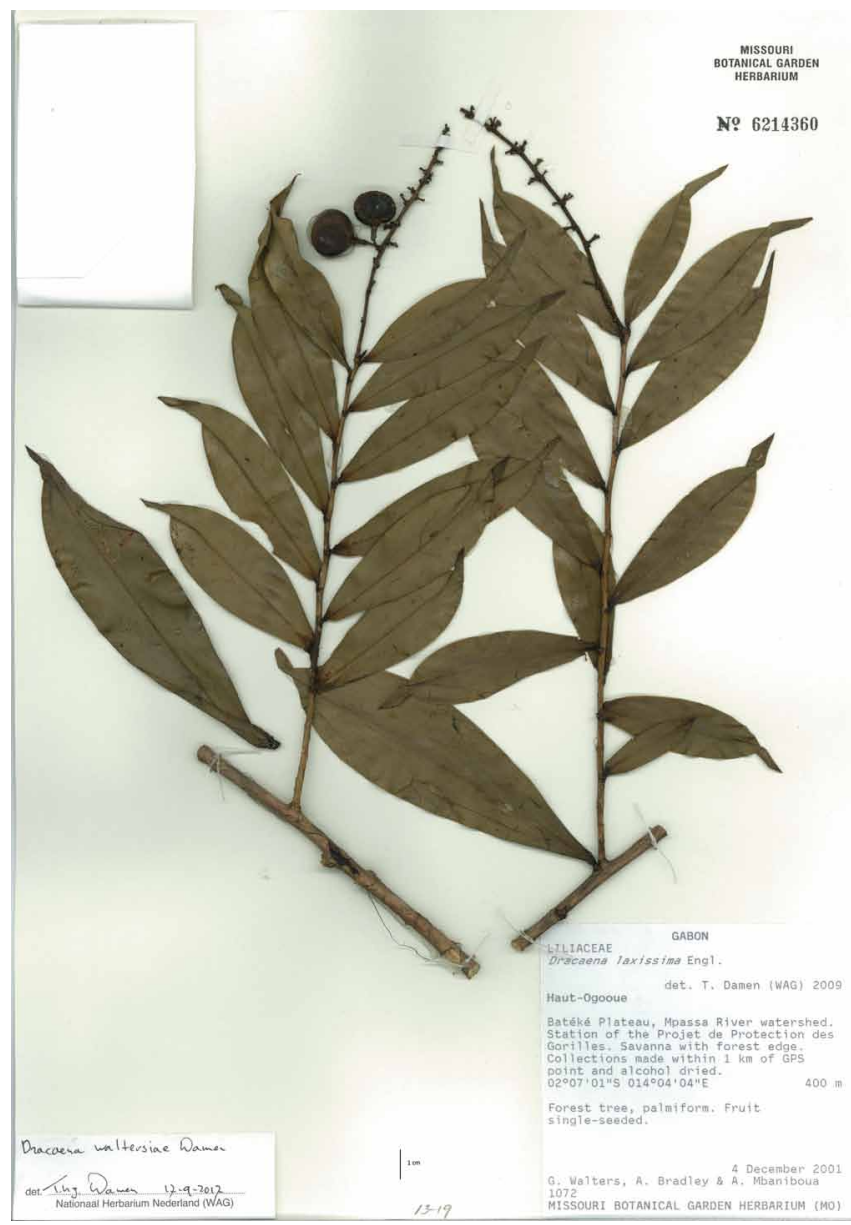

Plate 9 Dracaena waltersiae Damen, scan of herbarium sheet showing infructescence and leaf arrangement; Walters 1072.

pedicel 6-9 $\mathrm{mm}$ long, articulating at c. $1 \mathrm{~mm}$ from the apex, green-white, purplish near the apex; floral bracts inconspicuous, triangular, up to c. $1 \mathrm{~mm}$ long, scarious; perianth c. $27-28 \mathrm{~mm}$ long, with a pleasant odour, lobes $16-17$ by $1.5 \mathrm{~mm}$; stamens inserted near the throat, up to $4 \mathrm{~mm}$ shorter than the lobes, filaments filiform, anthers c. 2 by $1 \mathrm{~mm}$; style exserted for up to $1 \mathrm{~mm}$, stigma capitate, c. $0.9 \mathrm{~mm}$ diam. Fruits 1-3-seeded, depressed globose, c. 16 by $20 \mathrm{~mm}$ (in herbarium), red-brown; receptacle 3 by $2 \mathrm{~mm}$. Seeds not seen.

Distribution - Gabon, Central African Republic, Republic of the Congo.

Ecology - Edge savanna with forest, flooded forest, gallery forest, dry forest on white sand, Kalahari Sands, $50 \mathrm{~m}$ from edge of forest. Palisota and Memecylon in closed understory; at 400-620 m altitude. Flowering in March and April.

Other specimens examined. Central African Republic, Haut-Mbomou, region d'Obo, $\mathrm{PK} 57$, route de Zémio, c. N5 ${ }^{\circ} 20^{\prime}$ E26 $27^{\circ}, 31$ Dec. 1963 , Descoings, BM 12233 (MPU, P); ibid., 31 Dec. 1963, Descoings, BM 12238 (P). - GABON, Haut-Ogooué, Parc National des Plateaux Batéké, forêt proche du Bai Jobo (1.5 km), S2¹3' E13²50', 6 June 2005, Niangadouma, R 536 (MO); Batéké Plateau, Mpassa River watershed, station of the Projet de Protection des Gorilles, S2 $08^{\prime}$ E14 $14^{\circ} 04^{\prime}$, alt. 400 m, 4 Dec. 2001, Walters, GM 1072 (MO, WAG); Plateaux Batéké National Park, Mpassa River drainage, S2 ${ }^{\circ} 07.3^{\prime} \mathrm{E} 14^{\circ} 04.1^{\prime}$, alt. $460 \mathrm{~m}, 27$ Feb. 2003, Walters, GM 1138 (MO, WAG); ibid., S207.3' E14 04.1', alt. 460 m, 27 Feb. 2003, Walters, GM 1147 (LBV, MO, WAG). - Republic of the Congo, Pool, Pays Batéké, de Brazzaville à St. Joseph du Nkoué [= Kibouendé], S409' E1454', 29 July 1912, Chevalier, AJB 27333 (P); environs de Brazzaville, c. S4¹5' E15¹7', 10 Feb. 1971, Makany, L 1686 ( P).

Acknowledgements We are grateful to the curators of the herbaria and gardens mentioned under Materials and Methods, from which we borrowed and studied plant specimens. Special thanks to the people of Burgers' Bush,

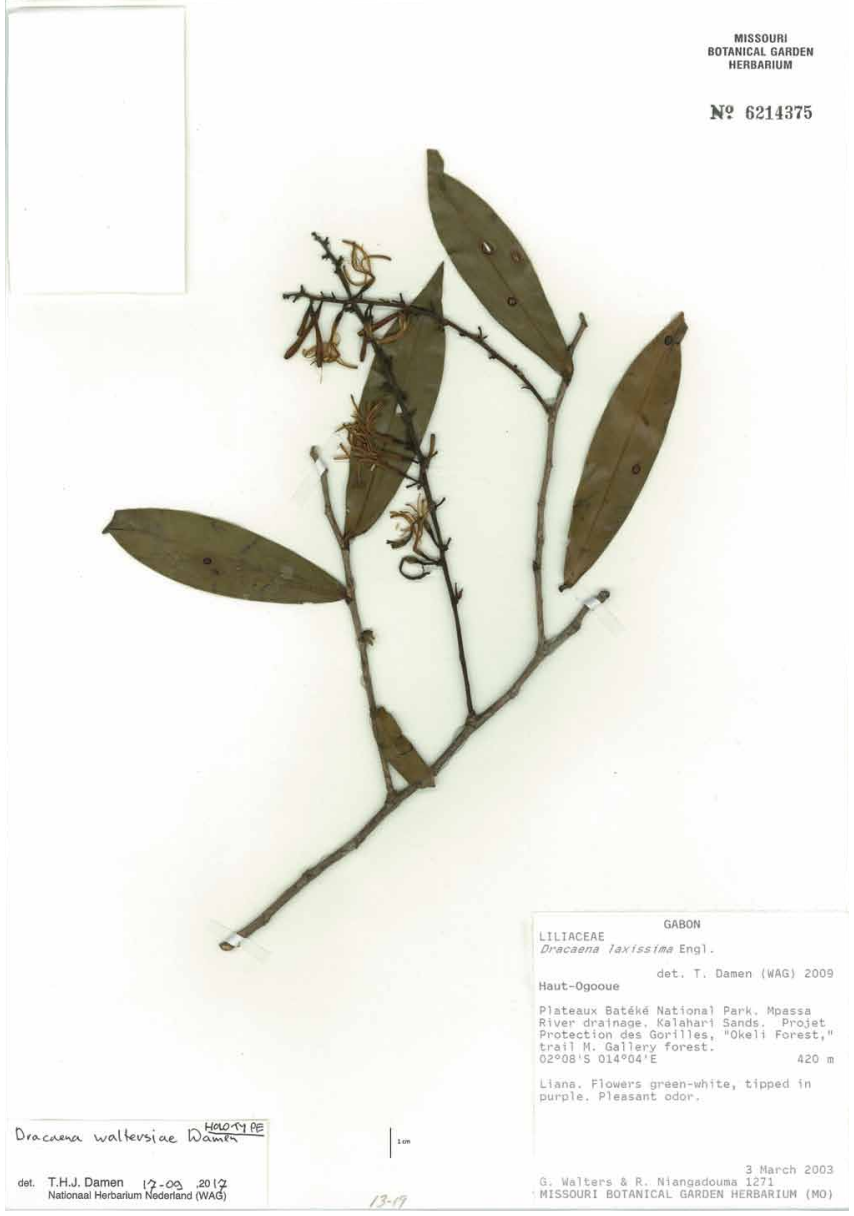

Plate 10 Dracaena waltersiae Damen, scan of holotype showing inflorescence; Walters 1271.

greenhouse of Burgers' Zoo, Arnhem, The Netherlands who cultivate the enormous Dracaena collection, invaluable to really understand the genus Dracaena. We thank the people working in the former WAG herbarium for all their help and discussions, special thanks to Frans Breteler, Wilbert Hetterscheid, Carel Jongkind and Jan Wieringa who served as a mentor to THJD and helped to solve the Dracaena mystery. THJD is much indebted to Erik Simons for his help and mental support, the Alberta Mennega Stichting, the Moabi Foundation and Hugo de Vries Fonds for additional funding for both field trips to Gabon (2013 and 2015). In this country, we gratefully appreciated the help of Raoul Niangadouma and Pulchérie Bissiengou from the LBV Herbarium in Libreville and the hospitality offered by WCS Gabon, IPHAMETRA, CENAREST and ANPN.

\section{REFERENCES}

Albuquerque S, Brummitt RK, Figueiredo E. 2009. Typification of names based on the Angolan collections of Friedrich Welwitsch. Taxon 58 (2): 641-646.

Angiosperm Phylogeny Group. 2016. An update of the Angiosperm Phylogeny Group classification for the orders and families of flowering plants: APG IV. Botanical Journal of the Linnean Society 181 (1): 1-20.

Aslam J, Mujib A, Sharma MP. 2013. In vitro micropropagation of Dracaena sanderiana Sander ex Mast.: An important indoor ornamental plant. Saudi Journal of Biological Sciences 20: 63-68.

Baker JG. 1874. On new Dracaenas from Tropical Africa. Journal of Botany, British and Foreign 12: 164-167.

Baker JG. 1875. Revision of the genera and species of Asparagaceae. (Continued). Journal of the Linnean Society of London, Botany 14 (80): 508-632.

Baker JG. 1878. XVII. Report on the Liliaceae, Iridaceae, Hypoxidaceae, and Haemodoraceae of Welwitsch's Angolan Herbarium. Transactions of the Linnean Society of London, 2nd Series, Botany 1 (5): 245-273.

Baker JG. 1898. Dracaena. In: Thiselton-Dyer WT (ed), Flora of Tropical Africa 7: 436-450. Reeve \& Co., London.

Baker JG. 1901. In: Schinz H, Beiträge zur Kenntnis der Afrikanischen Flora (suite). Bulletin de l'Herbier Boissier, sér. 2, 1: 853-857. 
Bos JJ. 1984. Dracaena in West Africa. Mededelingen Landbouwhogeschool Wageningen 84-1: 1-126.

Bos JJ. 1992. Dracaenaceae. In: Obermeyer AA, Immelman KL (eds), Flora of southern Africa, vol. 5 (3): 2-4. National Botanical Institute, Pretoria.

Bos JJ. 1998. Dracaenaceae. In: Kubitzki K (ed), The families and genera of vascular plants 3: 238-241. Springer Verlag, Berlin/Heidelberg/New York.

Bos JJ, Teketay D. 1997. Dracaenaceae. In: Edwards S, Mesfin Tadesse, Demissew Sebsebe, et al. (eds), Flora of Ethiopia and Eritrea 6: 76-82. The National Herbarium, Addis Ababa University, Addis Ababa

Brown NE. 1914. LIII. Notes on the genera Cordyline, Dracaena, Pleomele, Sansevieria and Taetsia. Bulletin of Miscellaneous Information, Royal Gardens, Kew 8: 273-279.

Budweg H-G. 2016. Die Blütenstände der Sansevierien. Sansevieria Online 4 (2): 4-24. http://www.sansevieria-online.de/lib/exe/fetch. php?media=hefte:so_2016_2.pdf.

Bull W. 1877. A retail list of new beautiful \& rare plants offered by William Bull No. 129.

Cheek M, Pollard BJ, Darbyshire I, et al. 2004. The plants of Kupe, Mwanenguba and the Bakossi Mountains, Cameroon. A conservation checklist. Royal Botanic Gardens, Kew, London.

De Roos J. 2014. A revision of species in the genus Dracaena, considering the D. aubryana complex. A Master biology thesis (BIS-80436), Wageningen University.

De Vogel EF. 1987. Manual of herbarium taxonomy: theory and practice. UNESCO, Jakarta.

De Wildeman ÉAJ. 1905. Mission Émile Laurent (1903-1904), vol. 1. Vanbuggenhoudt, Bruxelles.

De Wildeman ÉAJ. 1906. Annales du Musée du Congo Belge, Botanique V (1), fasc. III: $213-346$.

De Wildeman ÉAJ. 1915. Decades Novarum Specierum Florae Congolensis. Bulletin du Jardin Botanique de l'État à Bruxelles 5: 1-108.

De Wildeman ÉAJ. 1921. Études sur les récoltes botanique du Dr J. Bequaert chargé de missions au Congo Belge (1913-1915). Plantae Bequaertianae 1: $1-166$.

Durand T, Durand H. 1909. Sylloge florae congolanae (Phanerogamae), Liliaceae: 561-573. Maison A. de Boeck, Bruxelles.

Engler HGA. 1892. Liliaceae africanae. Botanische Jahrbücher für Systematik, Pflanzengeschichte und Pflanzengeographie 15 (35): 467-479.

Engler HGA. 1895. Die Pflanzenwelt Ost-Afrikas und der Nachbargebiete, theil C. Geographische Verlagshandlung Dietrich Reiner, Berlin.

Engler HGA. 1902. Liliaceae africanae II. Botanische Jahrbücher für Systematik, Pflanzengeschichte und Pflanzengeographie 32: 89-97.

Engler HGA, Krause K. 1910. Liliaceae africanae II-Dracaena. Botanische Jahrbücher für Systematik, Pflanzengeschichte und Pflanzengeographie 45: $123-155$

Filer DL. 2001. BRAHMS, Botanical research and herbarium management system. BioNET News 8: 6-7.

Govaerts R, Zonneveld BJM, Zona SA. 2017. World checklist of Asparagaceae. Facilitated by the Royal Botanic Gardens, Kew. Published on the Internet; http://apps.kew.org/wcsp/ Retrieved 10 Feb. 2017.

Hepper FN. 1968a. Notes on Tropical African Monocotyledons: II. Kew Bulletin 22 (3): 449-467.

Hepper FN. 1968b. Agavaceae. In: Hutchinson J, Dalziel JM, Hepper FN (eds), Flora of West tropical Africa, 2nd ed., vol. III: 154-159. Crown Agents for Oversea Governments and Administrations, London.

Hooker WJ. 1861. Botanical Magazine 87 (= ser. 3, vol. 17): t. 5248.

Hua H. 1897. Contributions à la Flore du Congo Français, famille des Liliacées. Bulletin de la Société d'Histoire Naturelle d'Autun 10: 655-678.

JSTOR. 2000-2016. Global plants. Available from http://plants.jstor.org [accessed 15 Feb. 2017]

Keay RWJ, Onochie CFA, Stanfield DP. 1964. Nigerian trees, vol. 2. Federal Government Printer, Lagos.

Krause K. 1914. Liliaceae africanae V - Dracaena. Botanische Jahrbücher für Systematik, Pflanzengeschichte und Pflanzengeographie 51: 440-450.

La Croix I. 2010. Dracaenaceae. In: Timberlake J (ed), Flora Zambesiaca 13 (2): 13-35. Royal Botanic Gardens, Kew, London.

Lu P-L, Morden CW. 2014. Phylogenetic relationships among Dracaenoid genera (Asparagaceae: Nolinoideae) inferred from chloroplast DNA loci. Systematic Botany 39 (1): 90-104.
Marrero A, Almeida RS, González-Martín M. 1998. A new species of the wild dragon tree, Dracaena (Dracaenaceae) from Gran Canaria and its taxonomic and biogeographic implications. Botanical Journal of the Linnean Society 128: 291-314

Masters MT. 1892. The Gardeners' Chronicle: a weekly illustrated journal of horticulture and allied subjects, ser. 3, 11.

Masters MT, Moore T. 1872. The Gardeners' Chronicle \& Agricultural Gazette 1872.

McNeill J, Turland NJ, Barrie FR, et al. 2012. International code of nomenclature for algae, fungi, and plants (Melbourne Code). Regnum Vegetabile 154. Koeltz Scientific Books, Konigstein.

Mildbraed GWJ, Perkins J. 1910. Liliaceae. In: Mildbraed GWJ, Perkins J (eds), Wissenschaftliche Ergebnisse der Deutschen Zentral Afrika Expedition 1907-1908, Bot. 2: 60-64. Klinkhardt \& Biermann, Leipzig.

Morsy AA, Elshahawy IE. 2016. Anthracnose of lucky bamboo Dracaena sanderiana caused by the fungus Colletotrichum dracaenophilum in Egypt. Journal of Advanced Research 7 (3): 327-335.

Mwachala G. 2005. Systematics and ecology of Dracaena L. (Ruscaceae) in Central, East and Southern Africa. PhD dissertation, Universität KoblenzLandau.

Mwachala G, Cheek M, Fischer E, et al. 2007. A new species of Dracaena L. (Dracaenaceae-Ruscaceae) from Mt Kupe and the Bakossi Mts, Cameroon. Kew Bulletin 62 (4): 613-616.

Mwachala G, Fischer E. 2013. Two new species of Dracaena (Asparagaceae, Nolinoideae) from Central Africa, with a note on the identity of D. braunii. Novon 22 (4): 442-446.

Mwachala G, Mbugua PK. 2007. Dracaenaceae. In: Beentje HJ, Ghazanfar SA (eds), Flora of tropical East Africa. Royal Botanic Gardens, Kew, London. Pellegrin F. 1930. Plantae Letestuanae novae ou Plantes nouvelles récoltées par M. Le Testu de 1907 a 1919 dans le Mayombe Congolais. Bulletin du Muséum national d'Histoire Naturelle, Paris, sér. 2, 2: 571-573.

Quantum GIS Development Team. 2017. Quantum GIS Geographic Information System. Open Source Geospatial Foundation Project. https://qgis.org. Rendle AB. 1911. Monocotyledons. In: Rendle AB, Baker EG, Moore S, et al. (eds), A contribution to our knowledge of the Flora of Gazaland: being an account of collections made by C.F.M. Swynnerton. Journal of the Linnean Society, Botany 40: 207-235.

Rendle AB. 1913. Liliaceae. In: Rendle AB, Baker EG, Wernham HF, et al. (eds), Catalogue of the plants collected by Mr. \& Mrs. P.A. Talbot in the Oban district South Nigeria: 112-113. Trustees of the British Museum, London. Sheridan M. 2008. Tanzanian ritual perimetrics and African landscapes: the case of Dracaena. International Journal of African Historical Studies 41 (3): 491-521.

Singh HP, Dadlani NK. 2000. 'Current status of floriculture - National and International Scenario'. Commercial Floriculture, Malhotra Publishing House, New Delhi.

Sosef MSM, Dauby G, Blach-Overgaard A, et al. 2017. Exploring the floristic diversity of tropical Africa. BMC Biology 15: 15.

Staner P, Boutique R. 1937. Matériaux pour l'étude des plantes medicinales indigènes du Congo Belge. Memoire de l'Institute Royale College de Belge. Institut Royal Colonial Belge Section des Sciences Naturelles et Médicales, Bruxelles.

Stevens PF. 2001 onwards. Angiosperm phylogeny website. Version 12 (July 2012) [and continuously updated since]. http://www.mobot.org/MOBOT/ research/APweb.

Thiers B. continuously updated. Index Herbariorum: A global directory of public herbaria and associated staff. New York Botanical Garden's Virtual Herbarium. http://sweetgum.nybg.org/ih/ [accessed 1 August 2017].

Venter F. 1996. The genus Dracaena L. in South Africa. Aloe 33: 62-64.

Watson L, Dallwitz MJ. 1992 onwards. The families of flowering plants: descriptions, illustrations, identification, and information retrieval. Version: 19 Oct. 2016. http://delta-intkey.com.

White F. 1983. Vegetation of Africa - a descriptive memoir to accompany the UNESCO/AETFAT/UNSO vegetation map of Africa; Natural Resources Research Report XX. U.N. Educational, Scientific and Cultural Organization, Paris.

Wijsman JCG. 2012. Land- en tuinbouwcijfers 2012 (LEI-rapport): 56. LEI, onderdeel van Wageningen UR / CBS, Den Haag. 


\section{INDEX OF EXSICCATAE}

Note: Initials are only added when there is more than one person with that surname in the list. Collections without number are delete from the list.

$\begin{aligned} \text { aca } & =D . \text { acaulis } \\ \text { acu } & =D . \text { acutissima } \\ \text { bic } & =D . \text { bicolor } \\ \text { bra } & =D . \text { braunii } \\ \text { bus } & =D . \text { bushii } \\ \text { cam } & =D . \text { camerooniana } \\ \text { cer } & =D . \text { cerasifera } \\ \text { con } & =D . \text { congoensis }\end{aligned}$

Abeid 2012: usa; 2323: usa - Achoundong 622: bus - Achten 66A: nit; 66B: nit; 310A: cam; 310B: cam; 536: san; 777A: aca; 777B: aca - Adam 3903: per; 5968: cam; 21241: per; 21420: cam; 25282: cam; 29737: cam-Adams 2128: cam; 2229: cer -Adjanohoun 118: per -Aké Assi 8387: cam; 8517: per; 9242: cam; 9478: cer; 9483: con; 9534: per; 15885: cer -Akoègninou 3090: mar - Akogo 249: cam - Allard 185: nit - Alluaud 382: ste - Amsini 282: nit - Andoh FH3728: per - Andrews A1978: lax - Angus 285: usa; 406: cam; 409: cam - Ankei 79/307: usa - Annet 289: lax; 347: cam; 411: cam - Antheunisse 40: cam; 49: cam; 50: cam - Apema 437: nit - Archer, AW 9206: ste -Archer, PG 712: usa - Ariwaodo 858: lax-Asonganyi 108: cam; 298: cam - Attims 46: cam - Aubréville AEF/CAM207: nit - Audru 6517: per - Auquier 4251: cam.

Baagøe 92: lax - Baker 262: lax - Baldwin Jr 6178: cam; 6472: cer; 7012: cam; 11348: cer - Ball 44246: usa - Bamps 785: usa; 1374: cam; 1666: tho; 1708: bra; 1744: cam; 2065: cer; 2312: cer; 2578: cam; 3146: ste-Barbosa 4433: usa - Barter 1511: per-Bates 1095: vir-Baudet 290: ste-Bavicchi 421: acu; 489: cam; 491: san - Becquet 457: ste; 942bis: ste - Beeckman 11: nit - Beentje 203: cam; 231: cam; 410: cer; 412: cam; 540: cer - Belesi Katula 261: nit - Bels 89: mar - Bequaert 1556: lax; 1578: san; 2252: cam; 2329: usa; 5007: ste; 6322: lax; 7185: nit; 7394: san; 7459: cam; 7921: aca - Bidault 904: glo; 917: glo; 1030: cam; 1459: lax; 1868: glo; 1889: per Bidgood 4840: lax; 6462: laf - Biegel 4625: ste - Bieler 40: san - Bilivogui 227: cam - Billiet S645: san; S2886: aca; S3161: cam; 4239: nit - Biloso Moyene 1: nit; 2: nit - Binuyo FHI35552: cam - Bissiengou 1351: cam Bitsindou 107: cam; 134: lax - Bjørnstad 840: usa - Blackmore 1041: lax; 1372A: ste; 1502: usa; 1527: lax - Bodenghien 395: cam - Bokdam 3200: san; 3297: cam; 3464: lax; 3480: lax; 3541: san; 3666: cam; 3735: man; 4355: cam; 4532B: nit; 4536: nit; 4537: cam - Bolema 835: cam - Borhidi 84/128: lax - Bos 3300: lax; 3452: cam; 3454: tho; 3475: bra; 3475A: bra; 3480: bra; 3510: tho; 3520: bra; 3547: cam; 3617: lax; 3640: tho; 3660: cam; 3697: tho; 3697A: cam; 3703: lax; 3730: vir; 3814: lax; 3816: vir; 3893: cam; 3895: cam; 3900: vir; 3915: tho; 3925: bra; 4022: tho; 4051 : tho; 4076: bic; 4102: bra; 4160: bic; 4161: vir; 4204: vir; 4229: cam; 4249: lax; 4259: bra; 4259A: bra; 4327: cam; 4340: cam; 4401: vir; 4471: bra; 4555: vir; 4578: lax; 4681: tho; 4682: cam; 4683: cam; 4684: cam; 4685: cam; 4686: cam; 4687: cam; 4688: cam; 4689: cam; 4690: cam; 4691: cam; 4692: cam; 4693: cam; 4694: cam; 4695: cam; 4696: cam; 4697: cam; 4698: cam; 4768: bic; 4775: man; 4785: man; 4800: man; 4800A: man; 4801: cam; 4825: cam; 4835: lax; 4858: cam; 4905: cam; 4972: lax; 4975: cam; 5035: cam; 5036: tho; 5103: bic; 5303: cam; 5375: tho; 5376: cam; 5407: lax; 5640: tho; 5756: cam; 5768: vir; 5816: tho; 5826: tho; 5990: tho; 6086: cam; 6102: vir; 6123: bra; 6181: cam; 6187: lax; 6405: cam; 6550: tho; 6612: cam; 6613: cam; 6631: bra; 6921: vir; 6922: lax; 6923: vir; 6980: cam; 7002: cam; 7034: cam; 7065: hae; 7085: cam; 7097: lax; 7180: tho; 7220: vir; 7261: lax; 7336: tho; 7337: lax; 7339: bic; 7344: vir; 7374: bra; 7379: bra; 7407: cam; 9437: ste; 10200: ste; 10268: vir; 10282: vir; 10290: vir; 10324: san; 10334: cam; 10337: cam; 10340: cam; 10361: cam; 10375: san; 10381: tho; 10386: lax; 10407: cam; 10408: cam; 10413: lax; 10420: cam; 10421: cam; 10427: cam; 10432: lax; 10535: con; 10556: tho; 10564: cer; 10565: cam; 10570: hae; 10571: hae; 10633: cam; 10640: man; 10641: con; 10699: vir; 10700: tho; 10705: man; 10749: cer; 10750: con; 10751: cam; 10769: lax; 10800: mar; 10805: cam; 10806: bra; 10820: cam; 10828: hae; 10833: vir - Bosch 361: cam - Boupoya-Mapikou 22bis: cam; 595: cam; 1047: nit; 1163: gol - Bouquet 123: nit; 265: acu; 481 : cam; BD667: cer - Bourobou 168: man; 470: nit - Boussiengui Nongo 118: cam - Bouxin 1318: lax - Boyekoli Ebale Congo 2010 Expedition 145 : san; 815: san - Bradley 1110: nit - Brass 16806: lax; 17614: ste - Braun 329: bra - Brédo 5336: cam; 6272: usa; 6355: usa - Brenan 8599: cam; 8988: con; 8991: con; 9045: cam; 9073: cam - Breteler 882: vir; 922: cam; 1981: cam; 2004: san; 2438: bus; 2673: cam; 2974: cam; 3043: bus; 5202 : cam; 5569: bra; 5661: cam; 5772: glo; 6020: cam; 6598: lax; 6609: cam; 6622: bic; 6765: cam; 7362: cam; 7414: cer; 7442: cer; 7507: lax; 7590: cam; 7609: cam; 7636: con; 7663: cer; 7673: cer; 7678: cam; 8081: bic; 8227: cam; 8250: cam; 8319: glo; 8343: cer; 8349: glo; 8412: cam; 8937: gol; 8938: bic; 9558: glo; 9794: glo; 9795: vir; 9876: cam; 9877: bic; 9997: cam; 10025: vir; 10053: lax; 10449: mar; 11012: bic; 11114: lax; 11171: vir; 11215: vir; 11229: bic; 11332: cam; 11383: san; 11781: lax; 11904: usa; 13325: nit; 13477: cer; 14438: vir; 14640: mar; 15153: nit - Breteler \& De Wilde 1: cam; 27: tho; 147: tho; 155: bic; 156a: gol; 239: cer; 351: aca; 398: glo; 406: bic; 496: cam; 551: vir; 581: cam; 602: tho - Breton 5307: cam Breyne 558: cam; 909: con; 1375: san; 1524: cam; 2319: cam; 2558: cam; 2559: san; 2765: aca; 2838: nit; 3143: acu; 5023: cam; 5210: cam - Bruce 1116: lax-Brummitt 9385: lax; 11289: lax; 13734: usa; 15134: lax-Brunel 4803: per - Brunt 289: per; 1119: per - Bryce 23: usa - Buchanan 25: ste; 1485: lax - Buchner 684: nit - Bullock 1106: cam; 1151: usa; 3331: usa; 3862: cam - Burger 1489: ste; 3642: ste - Burtt Davy 21141: lax; 21235: ste; 21555: lax; 22178: ste - Busse 303: ste - Büttner 531: nit; 537: glo - Buyck 9372: usa.

Cable 425: cam; 550: cam; 1236: vir - Cabu 157: ste - Callens 4161: cam Carlier 7: acu; 19: nit - César 1174: cam; 1512: cam; 3931: per - Chaffey 136: ste - Chalot 19: nit - Champluvier 5238: cam; 5374: acu - Chandler 1778: lax; 1861: ste; 2105: lax - Chapama 4: lax; 780: usa - Chapman, HM 80: lax - Chapman, JD 546: usa; 594: ste; 594B: ste; 1470: ste; 2658: lax; 2966: lax; 4598: lax; 5550: usa; 5661: lax; 5943: lax; 5979: usa; 6390: ste; 6418: usa; 9452: lax - Charter FHI42220: bic - Chase, MW 1239: gol - Chase, NC 388: usa; 707: usa; 875: usa; 2992: usa; 6186: ste - Cheek 3232: cam; 5155: bic; 5443: cam; 7476: bic; 11170: vir; 11637: vir - Chevalier 2572: per; 2575: per; 4004: nit; 4007: nit; 4008: nit; 5118: cam; 5291: cam; 10875: san; 10925: cam; 10926: san; 10927: cam; 11130: nit; 11213: acu; 12439: cam; 12490: cam; 12557: cam; 12658: cam; 12909: cam; 13216: cam; 13302bis: per; 13616: cam; 13744: lax; 14181: lax; 14489: lax; 14615: lax; 14967: cam; 16188: per; 16615: per; 19066: cam; 19806: cam; 22104: per; B22422: per; 22915: con; 22921: con; 25611: cam; 26328: glo; 27269: nit; 27333: wal; 27632: acu; 27725: nit; 27728: san; 28201: man; 33415: cam; 33649: mar - Chillou 463: per; 3787: per - Chipp 53: ste; 193: per-Christiaensen 1011: usa; 1216: lax; 1487: lax; 2072: cam - Chuwa 5163: usa; 6263: lax - Compaore 71: per - Compère 23: cam; 300: nit; 670: nit; 1736: cam - Congdon 626: usa; 666: lax; 697: cam - CorbisierBaland 852: nit; 1418: nit - Cornet d'Elzius 666: cam - Correia 2345: lax; 2495: usa - Cousens FHI7417: per - Coûteaux 19: nit - Cusset 569: lax; 1246: cam; 1359: acu; 1360: cer.

Dacremont 284: nit - Dale 3577: usa - Damen 311: bra; 460: aca; 463: bus; 481: tho; 482: tho; 483: tho; 484: tho; 491: cam; 499: bra; 500 : cer; 508: san; 524: glo; 532: cam; 534: bra; 536: bra; 541: bra; 543: bra; 545: bra; 551: bra; 552: bra; 558: bra; 610: wak; 615: man; 616: cam; 620: tho; 622: bic; 623: man; 624: man; 625: man; 626: man; 627: tho; 630: cam; 631: bic; 633: cam; 653: tho; 654: tho; 655: tho; 661: glo; 662: glo; 663 : cam; 666: glo; 667: vir; 671: mar; 674: lax; 675: glo; 676: cam; 677: man - Daniels 64: cam - Daramola FHI55516: vir; FHI62736: cam; FHI72332: cam - Darbyshire 227: man; 313: cam - Dauby 81: bra; 95: mar; 174: bra - Dawe 184: nit; 461: usa - De Bergeyck 1: cam - De Brazza 185: man - De Carvalho 2188: vir; 2571: vir; 2713: bic; 3028: vir; 3667: bic; 4898: cer; 4970: bra; 5011: bra; 5221: cer; 6324: bus - De Foresta 869: bra; 963: bic; 985: cam; 1001: vir; 1051: glo; 1165: nit; 1255: mar; 1256: aca; 1574: cam; 1594: san - De Giorgi 1069: cam - De Gomes-Sousa 1538: ste; 1715: usa; 1784: usa; 1785: usa; 2064: usa; 4591: usa; 4806: usa - De Koning 163: cer; 1864: cam; 2606: cam; 2610: cam; 3157: cam; 3160: cam; 3253: cam; 3256: cam; 3586: cam; 3751: cam; 3753: cam; 4662: cam; 5846: cam; 6557: per; 6559: per; 8176: usa; 9018: usa; 9517: usa - De Kruif 169: cer; 851: man; 883: cam; 915: nit; 946: man; 1381: lax - De Matos 7652: lax - De Mattos 138: san - De Namur 850: cam - De Néré 923: cam; 1716: cam - De Oliveira 12: lax - De Roos 1: san; 2: san; 11: bus; 18: aca - De Rouw 191: cam; 294: cam - De Saeger 1423: cam; 1532: cam - De Wilde (WALG), JJFE 126: lax; 231: lax; 332: lax; 378: lax; 406: lax - De Wilde (WALK-B), JJFE 305: gol; 308: cer; 423: nit; 481: wak; 654: bra; 775: cam - De Wilde, JJFE 640: per; 7541: man; 7593: cam; 7819: bra; 7849C: man; 7891: cam; 7928A: vir; 8050A: tho; 8123: cam; 8256A: cam; 8443: vir; 9073: nit; 9248: vir; 9529: glo; 9983: acu; 9984: 
acu; 10019: nit; 10025: tho; 10526: lax; 10581: lax; 10885: mar; 11557: lax; 11740: tho; 11990: bra; 12105: vir - De Wilde, WJJO 1127: tho; 1546A: cer; 1546B: cer; 1851: cam; 1999: cam; 2657: cam; 2718: cam; 2781: cam; 2907: bra - De Witte 282: san; 2571: cam; 3755: cam; 6147: cam; 6903: usa - Dechamps 13103: nit; 13105: nit; 13253: con - Deighton 2476: per - Delvaux 860: cam - Deman 153: vir - Demeuse 92: cam - Descoings 6190: nit; 7697: cam; 8394: vir; 8661: nit; 9217: san; 9554: nit; 11141: nit; 12238: wal; 12635: cam - Desenfans 3575: usa; 3820: cam - Devred 292: aca; 345: nit; 356: cam; 746: cam; 1004: cam; 1545: nit; 2106: nit; 2827 : lax; 3241: nit - Dewèvre 169: aca; 701: cam - Dewulf 92: san; 179: san; 190: cam; 551: cam; 626: nit - Dhetchuvi Matchu-Mandje 388: cam; 535: san; 1472: cam; 1565: cam; 1629: con - Diafouka 115: nit - Dibata 1111: bra - Dinklage 1274: lax; 2541: per - Do Espirito Santo, JVG 1911: per; 2053: per; 2252: per - Dodd 397: con - Donis 3: cam; 368bis: nit; 1359 : mar; 1393: nit; 1465: nit; 1787: mar; 1851: cam; 2027: nit; 2784: cam; 3288: cam; 3602: nit - Doumenge 76: cam - Dowsett-Lemaire 146: lax; 1500: mar; 1655: man - Droissart 760: vir; 1886: cam - Drummond 1702: lax - Dubois, J 196: nit; 439: cam; 440: cam - Dubois, L 1208: lax - Dümmer 4105: lax - Duparquet 100: nit - Duvigneaud 980: man; 1287: ste; 2443D2: usa; 3664D2: usa; 3696: usa.

Eimunjeze FHI69960: man - Ejiofor FHI14032: cam - Elad 1499: cam; 1504: tho; 1593: lax - Elbert 174: vir - Emwiogbon 272: lax; FHI60034: cam; FHI60660: cam - Eneme Efua 6: cam - Enti R725: cam; R804: per; FE2250: per; GC37543: per - Ern 2152: per - Etuge 2533: bic; 5170: cam - Evrard 892: nit; 1237: cam; 1358: nit; 1421: cam; 1513: lax; 1514: san; 2008: cam; 2064: san; 2138: cam; 2764: san; 2766: cam; 2896: cam; 2998: cam; 3020: cam; 3632: cam; 4380: cam; 4464: cam; 4787: cam; 5093: cam; 5258: laf; 5625: cam; 5677: cam; 5723: cam; 5831: cam; 5878: nit; 6128: cam; 6133: cam; 6656: nit - Eyles 6787: usa; 7006: ste; 8217: cam - Ezrom 27: usa.

Faden 74/1300: lax - Fakih 81: usa; 542: usa - Fandey 44: usa - Fanshawe 1006: usa; 1021: cam; 1367: cam; 3207: cam; 3538: usa; 4020: ste; 8207: cam; 8624: cam; 11631: lax - Farquhar 13: lax - Farron 4058: cam; 7323: san - Faulkner 81: usa - Fay 2162: man - Festo 971: lax - Figueiredo 62: lax - Flamigni 117: man; 165A: san; 325: glo; 10269: laf - Florence 820: glo; 902: cam; 968: cam; 1001: tho; 1522: cam; 1536: cam; 1625: cam; 1902: cam - Floret 1576: mar; 1655: cam; 1777: con - Friis 30: ste; 416 : ste - Froment 784: ste - Fromm 245: cam - Fruth 02/192: cam.

Gachathi 702: lax - Gaillez-Mahin 39: usa-Galoux 242: usa - Gane 130: usa - Gathy 1606: san - Gautier 181: san - Gavage 7: mar - Gbile FHI20531: con - Geerling 1536: cam - Geilinger 1086: usa - Gentil 79: con - Gentry 32708: per; 32807: lax; 33016: con; 33723: man; 52692: bic - Gérard 1675: lax; 2140: cam; 2161: san; 2677: nit; 5735: lax - Gereau 2787: lax; 4555: lax; 5886: usa; 7377: san; 7644: san - Germain 98: san; 180: cam; 239: nit; 1969: nit; 2450: acu; 2816: lax; 3019: lax; 4054: ste; 5131: bic; 7436: cam; 8159: lax - Gerstner 7166: usa - Ghesquière 2761: san - Gilbert 1597: lax; 1875: cam; 2353: cam; 7917: cam; 7919: nit; 8162: nit; 8183: cam; 8311: man; 8503: nit; 8893: nit; 9203: man; 9205: cam; 9219: man; 9938: cam; 10204: cam; 14320: acu; 14543: man; 14564: con - Gillet 339: cam; 1670 : nit; 2717: con; 2770: san; 2919: cam; 3333: cam; 3665: cam - Gilliland K916: ste; Q1859: usa - Goetze 154: usa; 1341: ste; 1464: lax - Golding 33: usa - Goossens 2998: san; 4171: cam; 4973: glo - Gorbatoff 301: nit - Gossweiler 651: nit; 5119: aca; 5505: aca; 5875: aca; 6179: cam; 6643: man; 6694: vir; 7738: glo; 7770: vir; 7770A!: vir; 8096: nit; 8217: cam; 8256: man; 8505: mar; 8995: nit; 10116: aca; 11194: cam; 14048B: san; 14127: cam - Goyder 3128: cam - Greenway 1546: ste; 2335: usa; 2628: usa; 4698: usa; 6032: ste; 8199: usa; 8219: usa - Groenendijk 677: usa; 885: usa - Groome 37: usa - Grosvenor 1232: lax - Groves 43: vir; 144: vir-Gutzwiller 523: san; 1122: ste; 1343: cam; 1356: ste; 1469: usa; 1757: cam; 2071: lax; 2275: usa; 3719: cam - Gyakari 608: per.

Haba, PK 283: cam - Haba, PM 93: cam - Hacquart 3: acu - Haerdi 182/0: usa; 595/0: ste - Hall, AV 473: usa - Hall, JB 3069: vir; GC38524: cam; GC42394: con - Hallé 1412: cam; 2091: mar; 2339: cam; 2340: gol; 2637 : man; 2829: tho; 3589: tho; 4336: cer; 4395: cam; 4443: aca; 5161: lax; 5198: aca; 5289: cam; 5311: cam; 5362: tho; 5469: bra; 5956: lax; 5982: wak; 6102: bic; 6472: nit - Harder 1500: lax; 2171: usa; 2195: usa; 3003: cam - Harley, RM 9234: lax; 9254: usa - Harley, WJ 456: cam - Harris, DJ 1131: cam; 2261: cam; 5659: san; 8245: bra; 8381: cam; 9567: cer Harris, T 90: lax; 538: lax - Hart 459: usa; 497: cam; 1439: cam; 1477: cer - Hecketsweiler 534: man; 535: man; 536: man; 537: man; 538: man; 539: man; 540: man; 541: man - Hédin 401: nit - Hemp 1358: lax; 4365: lax-Hendrickx 139: cam; 1346: lax-Hepper 4164: san; 7961: cam; 8114: con - Heudelot 86: per - Higgins 11725: ste - Hilliard 4632: lax - Hinno 294: vir-Hladik 2103: man; 2859: bic - Holland 195: gol - Holst 3260: ste Hombert 61: cam - Honey 762: usa - Hooper 35: cam - Hornby, AJW 2940: usa - Hornby, RM 3069: usa - Hort Bot Utrecht 75/335: cam - Houssin SRFG516: bic - Howard 8: man - Hughes 1768: per - Hulstaert 229: nit; 1068: cam - Humbert 17144: lax - Hunt 54: lax - Hutchinson 4115: cam.
Ichikawa 150: cam - IRD Plot 1390: cer - Irvine 315: per; 1097: cer; 1176: con; 2181: cer

Jacques-Félix 3043: man - Jaff 250: cam - Jangoux 513: cer - Jans 532bis: cam; 730: gol - Jansen 1108: cam - Jefford 2594: usa; 2600: usa - Jeffrey 311: cam - Jespersen 27: cam; 203: usa - Joffroy 194: lax; 205: lax - Johnson 730: con; 731: con; 870A!: per - Jongkind 1418: con; 2196: per; 2545: con; 2766: con; 3754: cam; 4456: cam; 4481: cam; 4666: cam; 5023: cam; 5293: cam; 5810: cer; 5895: bra; 6347: cam; 7203: cam; 7487B: cam; 7766: cam; 8871: cam; 9654: cam; 10521: con; 10730: cam; 11478: per; 11562: cam; 12326: cer; 13093: cam.

Kami 1339: nit - Kamulete 30: nit - Kayombo 868: usa; 1955: lax; 2913: lax; 3157: lax; 6636: lax; 6963: laf - Kenfack 1051: bic - Kennedy 1135: cam; 1783: cam; 2645: cam - Khayota 485: cam - Kibure 294: usa - Kibuwa H201: lax; H203: ste - Kikufi 4: nit - Kimpouni 1119: acu - Kindeketa 48: lax; 2614: usa - Kinloch 3230: cer - Klaine 104: glo; 118bis: cam; 162a mar; 278a: cam; 400bis: mar; 455a: mar; 466: cam; 802: cam; 1629: nit; 1702: glo; 2107: lax; 2266bis: glo; 2982: glo; 2983: glo; 3132: glo-Koechlin 826: cam; 5046: vir; 5232: aca - Koenen 5: cer; 30: cam; 56: cam; 157: lax - Koritzschoner 1336: ste - Kouassi 15: per - Koufani 186: cam - Kouka 84: vir; 140: nit - Kouob 534: cer - Kuchar 22244: lax.

Lachenaud 1144: cam; 1145: bra; 1268: glo - Lane 109: vir; 286: bic; 526: vir; 533: bic - Lane-Poole 189: per - Lap 238: usa - Latilo FHI22745: per; FHI47677: per; FHI67540: lax - Laurent, É 2009: man - Laurent, MDJ 26: nit; 406: cam; 1122: nit; 2004: cam; 2007: nit - Lawton 1599: usa - Le Testu 175: lax; 474: usa; 970: bra; 1301: cam; 1376: vir; 2001: cam; 2972: lax; 2972bis: lax; 3466: cam; 4039: nit; 4378: lax; 4470: con; 5825: lax; 7242: man; 7853: lax; 7898: cam; 8282: nit; 9113: lax; 9144: cam - Le Thomas 10: bra - Leach 9122: usa - Leal 502: cam; 942: lax; 975: cam; 977: bic; 1010: cam; 2158: tho - Lebrun 259: nit; 1019: cam; 1028: nit; 1283: cam; 1546: san; 2508: nit; 2688: cam; 4283: lax; 4790: ste; 5373: lax - Lecomte E20: cam - Ledermann 1483: vir; 6119: vir - Leemans 63: nit; 2063: nit - Lees 65: lax - Leeuwenberg 2217: cam; 3000: per; 5138: cer; 5995: cam; 6322: cam; 6846: lax; 7938: per; 7995: cer; 8108: cam; 8727: lax; 8750: cam; 8806: lax; 8816: bic; 8818: bic; 8878: san; 8885: cam; 9073: lax; 9087: bic; 9125: cam; 9151: cam; 9240: bic; 10008: man; 10311: per; 10334: hae; 10602: bic; 10611: cam; 10664: nit; 11080: vir; 11159: per; 11202: per; 11251: man; 11256: con; 11258: cam; 11264: cam; 11318: cam; 11393: cam; 11411: con; 11460: cam; 11462: cer; 11468: nit; 11513: cam; 11576: cam; 12017: cer; 12047: cam; 12091: cer; 12309: cam; 12487: cam; 12535: cam; 12552: cam; 13597: lax - Lejoly 81/278: nit; 81/537: lax; 82/634: san; 84/683: lax; 86/200: con; 86/215: nit; 86/1129: san; 99/270T7: cam; 99/377: cam; 128: cer; 708: san; 786: nit; 1395: lax; 2650: san; 3488: cam; 3927: nit; 4192: san; 4442: lax; 4457: cam; 4724: san; 5214: nit; 7233: cam; 7262: cam; 7283: nit - Léonard, A 1011: san; 1082: nit; 1511: lax; 1612: usa; 1771: cam; 2331: lax; 2542: ste; 3617: lax; 5399: lax; 5767: usa - Léonard, JJG 231: cam; 590: nit - Lescrauwaet 35: nit; 149: con - Letouzey 1406: man; 1538: cam; 2289: lax; 2649: cam; 2685: vir; 2835: cam; 2971: nit; 3627: lax; 3996: vir; 4208: cam; 4934: cam; 7445: cam; 7571: lax; 7638: lax; 8443: cam; 9107: bic; 9120: bic; 9125: bic; 9376: cam; 9546: cam; 9616: san; 9621: cam; 9929: vir; 9992: cam; 10042: bic; 10228: bus; 10423: cam; 10573: cam; 10984: per; 11274: cam; 11703: cam; 11728: san; 11921: cam; 12324: cam; 12327: bic; 12429: gol; 12532: bic; 12929: lax; 13531: cam; 13631: vir; 13692: lax; 13727: mar; 13757: gol; 13823: bus; 13844: cam; 14304: cer; 14337: cam; 14603: cam; 14626: bic; 14965: lax; 15073: cam; 15135: bic; 15141: aca; 15179: bic; 15183: vir; 15289: vir; 15323: bic - Lewalle 868: ste; 1533: ste; 1779: cam; 2643: usa; 3347: usa; 3597: lax; 4092: usa - Liben 1987: nit; 2600: cam; 3288: san; 3338: nit; 3445: san; 3558: nit; 3737: lax - Liégeois 32: nit - Linder 765: cam; 1727: lax - Lisowski M93: bra; M271a: glo; M415: bic; C579: nit; M585: bra; C602: vir; M614: bus; M850: gol; M1279: cam; 2179: cam; 2555: usa; B3523: san; B3616: san; 3693: usa; B4542: acu; 4955: cam; 5078: cam; 5623: cam; B6952: nit; B7032: cam; B7352: cam; 8910: usa; 9109: ste; 10123: ste; 10137: lax; 11553: cam; 11920: ste; B13882: nit; 15611: cam; 16034: cam; 16071: cam; 16721: nit; 17098: cam; 17259: san; 18418: nit; 18845: san; 24298: cam; 24299: cam; 24300: cam; 24301: cam; 24302: cam; 24308: ste; 24309: usa; 24310: usa; 24311: usa; 24312: usa; 40082: nit; 40274: nit; 40408: cam; 41607: lax; 41641: san; 43179: san; 43720: nit; 44357: cam; 47190: nit; 48403: cam; 49843: san; 52579: nit; 80127: laf; 81913: cam; 86299: cam; 86351: san; 86494: san - Lock GC43969: con - Louis, AM 216: cam; 220: cam; 647: bic; 892: aca; 929: cam; 1261: lax; 1526: bra; 1529: cer; 1829: mar; 1859: bus; 2658: bra; 2749: wak; 2904: cam; 2981: cam; 2987: cam; 3011: cam; 3055: cam; 3282: mar; 3289: mar; 4001: bra; 4034: mar - Louis, JLP 43: nit; 83: cam; 157: nit; 585: man; 1131: san; 1188: nit; 2167: nit; 3589: man; 3813: nit; 4150: man; 4356: lax; 6396: lax; 7194: san; 7533: cam; 8937: san; 9434: lax; 9615: nit; 9618: aca; 10703: cam; 10987: cam; 11252: cam; 12240: man; 13378: nit; 14053: nit; 14099: bic; 14223: cam; 16798: man - Loveridge 
642: lax - Lovett 3487: lax; 3712: ste; 4829: ste; 4989: lax - Lowe 2043: cam; 3199: san; 3413: bra; 3614: bra; 4531: per - Luja 232: san - Luke, PA 5348: ste - Luke, WRQ 7729: ste; 9938: usa; 10503Z: cam; 11904: cam; 12115: cam; 12905: usa; 13009: vir; 13067: lax; 13342: cam - Lukuesa 60: usa - Lye 3782: lax; 3799: Iax; 6166: Iax; 6330: lax - Lyon FH2873: con.

Maas 10087: cam - Maas Geesteranus 5307: ste - Mabberley 692: usa - Macêdo (Mozambique) A1105: usa - Magogo 154: usa; 1061: usa Maitland 1686: lax - Makany 1686: wal; 1806: acu; 1816: acu - Malaisse 4555: usa; 10517: usa; 13330: cam; 13866: cam; 14560: per; 14801: per - Malchair 157: con - Mambo 162: cam; 168: cam - Mangambu 2074: lax - Mann 8A!: hae; 98: bic; 1037: bic; 1038: bra; 1204: cam; 1630: glo; 2328: bic; 2329: man - Marlier-Spirlet 1508: nit - Maron 41: nit - Masens 290: nit; 360: glo; 365: cam; 490: glo - Mathey 238: per - Maudoux 287: nit; 1131: nit - Mayombo-Nzengue 298: cam; 323: bic - Mbago 2137: usa - Mbamba 74: bra - Mbambi 146: cam - Mbani 148: cam - McPherson 15834: cam - Mertens 113: per - Mestdagh 39: san; 421: cam - Meyer 7982: ste - Mezili 90: bra - Mhoro 6310: ste - Michelmore 620: usa - Michelson 77: nit; 145: nit - Mildbraed 4976: vir; 10571: vir - Milne-Redhead 8545: usa - Minkébé Series S2: cam; W255: vir; A289: man; W506: cam; W525: cam - Moll 7113: san - Moloney 2: mar -Moor 2116: vir - Mortehan 43: cam; 713: cam - Morton SL899: per; GC9777: per - Mosango 582: tho; 605: cam - Moungazi 1475: bus; 1589: cam - Moutsamboté 4519: man; 6475: vir; 6632: aca; 6633: cam - Mpom 505: cam - Muasya NMK705: usa - Mullenders 1805: nit - Murphy 687: per - Mutimushi 3033: cam - Mwangoka 253: usa; 609: lax; 942: lax; 1594: laf; 2306: lax; 3380: usa; 3835: lax; 5096: lax - Mwasumbi 3622: usa; 16311: lax; 16613: usa - Myers 8386: ste.

N'Kounkou 115: cam; 116: vir - Nannan 24: nit - Ndam 608: lax; 653: cam; 747B: lax - Ndolo Ebika 207: cam - Nemba 625: cam - Ngansop 235: cam - Ngok Banak 1099: cam; 1397: tho; 1448: nit; 1781: tho - Ngombou Mamadou 99: cam - Ngomo 226: lax; 380: cam - Nguema Ekomo 776: acu; 949: bra; 950: cam - Nguema Miyono 1863: lax - Nguembou Kamgang 776: lax - Niangadouma 166: acu; 347: cam; 352: acu; 536: wal - Nimba Botanic Team WE495: per - Nkeng 35: cam; 75: cam - Nkhoma 13: usa - Nkongmeneck 465: bic; 508: cam; 1517: lax - Ntore 7: lax - Nusbaumer 653: cam.

Obama 138: lax - Obeng-Darko 1027: per - Odewo 258: cam - Ogonovszky 325: lax - Okafor FHI36851: man - Oldeman 984: cam - Olorunfemi 493: cam - Onana 13: cam; 30: lax - Onochie FHI31243: cam; FHI33171: Iax; FHI34321: lax; FHI36231: bic; FHI36435: vir - Onyeachusim FHI54072: per - Opara ARS1165: bic - Osborne 188: vir.

Parmentier 304: lax; 315: nit; 372: vir; 611: cam; 769: cer; 772: cer; 780: cam; 820: cam; 2234: nit; 2711: lax; 3056: lax; 3071: cam; 3101: cer; 3112: bic; 3372: cam; 3511: cam; 3994: nit; 5043: bic; 5105: bic; 5191: bic; 5369: lax; 5511: lax; 5556: lax - Patel 7249: lax - Pauwels 145: nit; 711: acu; 1928: nit; 3699: cam; 4841: cam; 4890: cam; 4917: acu; 6602: san - Pawek 10034: lax; 10087: usa; 10676: usa; 11280: lax; 13198: lax; 13408: lax Pedro 4395: usa; 4441: usa - Peeters 208: nit - Perdue 8239: ste; 9037 : ste - Pereira 882: usa; 885: usa; 1400: usa; 1524: usa - Pérez Viso 585: vir; 1988: bra - Perrottet 785: per - Peter 305: lax; 3512: lax; 3532: usa; 3700: lax; 3710: lax; 7066: lax; 8203: usa; 8906: lax; 9029: lax; 10319: lax; 13063: lax; 13906: usa; 14012: lax; 15756: lax; 16497: lax; 16736: lax; 16775: lax; 16917: lax; 18536: usa; 19449: usa; 19546: usa; 21557: lax; 21895: lax; 25248: usa; 31549: usa; 38690: usa; 40189: lax; 40386: usa; 40871: lax - Phillips 723: lax; 3105: usa - Pichi Sermolli 2010: ste - Pierlot 255: usa; 758: usa; 1113: lax; 1142: lax; 1778: man - Pirozynski 180: usa - Pittery 226: cam; 533: cam - Plot Series Mt Cameroon W493: cam Plumptre 76: cam - Pobéguin (Guinea series) 613: cam; 1429: cam; 1922: cam - Pobéguin (Moyen Congo series) 240: nit - Pogge 1434: san; 1456 : san; 1462: lax - Pohl ZRE86: nit - Poisson 11: per - Pole-Evans 1862: usa - Pollard 588: lax - Pope 1398: usa - Portères Lamto20: per-Preuss 146: cam - Procter 512: usa - Provincial Forest Officer 3: per - Pynaert 146: cam; 550: cam; 1461: san.

Quarré 4948: ste - Quartin-Dillon 103: ste - Quené 18: ste - Quintas 1: lax - Quiroz-Villarreal 1143: cam; 1782: wak; 1805: nit; 1856: nit.

Raimundo 931: nit - Randrianaivo 1651: lax - Raymakers 43: vir; 72: bra - Raymond 79: usa - Raynal 9833: cer; 13473: cam; 13494: bra - RaynalRoques 20852: ste - Reekmans 1422: usa; 2733: lax; 8238: ste - Reitsma 814: bra; 1052: nit; 1267: cer; 1803: cam; 2105: bic; 2114: cam; 2150: cer; 2212: cam; 3002: vir; 3016: aca; 3053: tho; 3184: mar - Reygaert 205: man - Richards 458: usa; 1845: cam; 5561: cam; 13199: usa; 15266: cam; 26419: lax; 26910: lax - Richardson 250: bus; 256: bic; 261: bus Risopoulos 666: nit - Robertson, RG 235: usa - Robertson, SA MDE22: ste; MDE202: ste - Robinson 3821: usa - Robson 202: lax; 482: lax; 1365 : lax-Robyns 473: cam; 841: nit; 4245: nit - Rose 415: lax - Runyinya 454: lax; 852: ste; 875: ste - Rwaburindore 2885: lax.

Sacleux 593: usa - Saint-Clair Thompson 1094: cam - Salubeni 553: lax Sanane 87: cam; 907: usa - Sanford 6027: bus - Sargos 114: man; 217: man - Satabié 79: per; 100: bic; 172: aca; 1097: bic - Schaijes 2306: cam - Schlieben 1765: lax; 2660: usa; 3377: lax; 4262: ste; 5540: usa Schmidt 1690: vir; 2018: cam - Schmitz 266: cam; 645: cam; 2091: usa; 3491: cam; 5700: usa; 6161: usa; 8033: ste - Schnell 949: cam; 2329: cam; 3922: cam; 3931: per; 4782: cam; 5146: cam - Schoute IIC19: nit Scott-Elliot 4551: cam; 5009: cam - Sebsebe Demissew 4986: bic; 5009: bic - Semsei 1006: usa; 1892: usa; 2536: ste; 3644: ste - Senterre 2787 vir; 6937: cer; 6955: cam - Seret 197: san; 397: cam; 935: san; 1229: aca - Shabani 818: lax - Shu Neba X225: lax; X382: lax; X728: lax; X899: lax; X1140: lax; X1672: cam; X2197: lax; X2204: cam; X2327: lax; X2599: lax; X2755: con; X3040: lax; X3165: lax; X3489: lax; X3699: cam; X3709: lax X3754: cam; X3767: lax; X3809: cam; X3888: lax; X3930: cam; X4053: con; X4143: lax; X5505: cam; X5612: man; X6245: cam; X8129: cam; X8137: con; X8208: con; X8622: cam; X8787: vir; X9124: con; X9373: con - Sidwell 107: cam; 346: bic - Sillitoe 270: lax - Simon 1077: usa - Simons 412: bra; 501: bra; 615: lax; 1048: bra - Sita 539: cam; 1476: cam; 1599: san 1601: cam; 1696: san; 1943: vir; 2481: vir; 3200: cam; 3276: lax; 3335: lax; 3414: vir; 3621: bra; 3673: tho; 3858: lax; 3894: cam; 4038: lax; 4660: con; 5083: bic; 5097: cam; 5287: cam; 5340: vir - Sitoni 718: lax - Smits 58: tho; 88: tho; 92: lax; 98: con; 112: cam; 113: vir; 116: vir; 144: lax; 213: lax; 227: vir; 236: lax; 258: vir; 326: vir; 432: lax; 448: cam; 513: cam; 524: lax - Smittenberg-Visser 113: per - Soleman 7572: usa - Sonké 1420: cam - Sosef 349: lax; 711: cam; 941: nit; 961: cam; 1225: cam; 1346: cam; 1659: bra; 2458: tho; 2796: nit - Soyaux 61: cam; 98: glo; 158: glo - Spitaels 291: cam - Staner 1828: ste - Stanfield FHI47067: mar - Staples 631: san - Staudt 784: lax - Stauffer 563: ste - Steudner 477: ste - Stévart 81: lax; 1082: lax; 3397: cam; 3962: cam; 4792: mar; 4794: cer - Stolz 117: lax - Stone 3663: nit - Streel 29: usa; 120: usa; 279: cam - Stuhlmann 8744: usa - Sturgeon GH18273: usa - Sunderland 1028: cam; 1333: cam; 1341: lax - Swynnerton 80: usa; 80bis: usa; 725: ste - Symoens 304: cam; 12354: cam - Sys 6: lax - Szafranski 1310: cam.

Taita Hills Expedition 1076: lax - Talbot 729: vir; 730: cam; 1322: bic; 1532: bic; 2404: bic - Tanner 5262: ste - Tawakali 247: lax - Tchouto Mbatchou T101X19: glo; T101X36: tho; LIKOX48: cam; MELX78: vir; EGONX87: cam; EGONX92: vir; T4X95: vir; EBIX107: cam; EFOUX111: cam; T3X113: bic; T3X134: vir; T2X288: cam; EGONX308: lax; T2X373: glo; 477: cam; 539: cam; 540: lax; 863: lax; 864: cam; 2879: lax; 2969: glo; 3069: cam; 3348 bra - Tekwe 103: bic; 131: cam - Terashima 169: usa - Tesfaye Haile 836: ste - Tessmann B153: vir; 358: man; 455C: cam; 466: lax-Texier 370: cam; 371: cam; 542: cam; 700: nit; 1042: cam; 1166: cam; 1188: lax - Thiébaud 224: nit; 616: nit - Thijssen 13: cer; 160: cam - Thollon 91: tho; 913: acu; 1222: cam; 4074: cam - Thomas, AS D58: con - Thomas, DW 417: cam; 915: cer; 2246: lax; 2265: cam; 2568: lax; 3168: vir; 4507: per; 4871: gol; 4872: cam; 5098: bus; 5436: bic; 6796: aca; 7404: lax; 7833: lax; 7834: cam - Thomas, NW 156: man; 1026: per; 2305: con; 4169: cam; 9591: per - Thompson, HN 506: per - Thompson, SA 5851: lax; 5976: lax; 6058: ste-Thomson 8: man; 17: bic - Thonet 210: nit - Thonner 262: nit - Thulin 952: ste; 1189: mar - Tilquin 182: nit - Timberlake 4939: usa; 5079: lax; 5366: usa; 5421: lax; 6008: lax - Tisserant (Équipe) 814: man; 1922: cam; 2247: cam - Tisserant 646bis: cam; 2122: nit - Toka 24: nit; 29: nit; 215: nit - Topham 32/21A: usa; 792: usa; 899: ste - Toussaint 203: nit; 318: nit; 2334: cam; 2483: nit - Towns 1235: cer - Traoré 115: cam - Trapnell 1779: usa - Trochain 7918: vir; 8363: vir - Troupin 14: cam; 242: cam; 257: cam; 5403: lax; 5445: lax; 5458: lax; 6348: lax; 7706: nit; 9177: lax; 9197: lax; 9261: lax; 10248: nit - Tshibarba TW61990: nit - Tuley 1042: vir. Ugbogu 15: bic - Ujor FHI27999: lax; FHI30833: gol - Unknown SCA1925: vir - Unreadable 680: cam.

Van Andel 3569: tho; 3635: tho; 3644: cam; 3730: cam; 4201: bra - Van Caekenberghe 52: bus - Van den Brande 192: vir - Van den Burg 16: bus; 40: bus - Van den Houdt 440: lax - Van den Houten 19: vir - Van der Ben 1905: lax; 2120: lax; 2297: lax - Van der Burg 289: cam; 478: per; 478A: per; 818: cam; 1023: cam; 1180: per - Van der Burgt 887: cam; 1479: per; 1662: cam; 1903: gol - Van der Laan 230: cam; 793: bra; 829: cam; 830: bus; 1040: tho; 1188: lax; 1235: lax; 1236: lax; 1274: usa; 1320: bra - Van der Linden 28a: lax - Van der Maesen 5528: con; 5542: cam; 6625: per - Van Doorn 33: cam; 80: cer; 81: per; 210: per; 211: per; 212 : per; 213: per - Van Gemerden 22: vir; 40: con; 64: vir; 91: lax; X650: cam; X751: vir; X1053: lax; X1171: lax; X1382: vir; X1687: lax - Van Meer 1661: cam; 1753: vir; 1837: vir - Van Nek 588: cer - Van Setten 579: lax; 845: hae; 979: aca; 980: vir; 983: lax; 984: con; 988: bus; 991: hae; 1061: hae; 1076: san - Van Someren 2298: ste - Van Valkenburg 2990: cam - Van Veldhuizen 981: tho; 982: hae; 1298: glo; 1302: con; 1355: hae; 1386: glo; 1428: glo; 1430: con; 1539: hae - Vanden Berghen 3573: per; 4024: per; 5401: per - Vanden Brande 4948: ste - Vanderyst 1907: nit; 1926: san; 2002: san; 2003: san; 2105: san; 2302: san; 2328: san; 2425: san; 3547: san; 3549: cam; 4133: san; 4346: cam; 5884: san; 8741: lax; 8808: nit; 9564: glo; 9836: glo; 9912: nit; 9945: glo; 9961: glo; 10169: nit; 12367: gol; 14414: cam; 14943: nit; 15359: cam; 15372: acu; 15634: cam; 16060: 
glo; 17115: con; 17178: nit; 17187: lax; 17421: acu; 19174: cam; 23624 : nit; 23755: nit; 24241: nit; 25043: nit; 27776: nit; 27820: nit; 28934: cam; 29880: nit; 29954: nit; 33788: nit; 34511: cam; 34607: cam; 35062: cam; 35067: cam; 35143: nit - Vaughan 1263: usa; 2156: usa - Veldkamp 6127: con - Verdcourt 5277B: usa - Verger 333: per - Verjans 102: per - Vermoesen 1241: mar; 1814: nit - Verschueren 359: aca - Versteegh 691: per; 707: cer - Vigne FH1634: per; FH2478: per; FH4091: cam - Villiers 160: glo; 2369: cam; 2488: cam; 2497: lax - Volkens 65: usa - Vollesen 221: lax - Von Rege 108: cam - Voorhoeve 286: per.

Wagemans 230: nit; 548: cam - Wallace 756: usa - Walters 624: gol; 625: gol; 941: nit; 1072: wal; 1138: wal; 1147: wal; 1271: wal; 1667: cam; 1710: acu; 1955: acu - Warnecke Amani441: lax - Watts 180: cam; 213: lax; 271 : cam; 350: lax; 379: lax; 609: cam; 615: lax; 718: cam; 794: cam; 816: lax; 817: cam; 1019: bic - Welwitsch 3741: nit; 3742: nit; 3743: nit; 3745: tho; 3746: tho; 3747: tho; 3748: cam; 3752: aca; 3753: aca - Wheatley 288: lax; 316: cam; 320: lax; 734: cam - Whellan 223: usa - White 2755: lax; 3047: ste; 3095: usa; 3405: cam; 3527: usa; 3725: lax; 3777: ste; 3796: lax - Whyte 87: ste - Wieringa 268: tho; 544: cam; 650: cam; 1148: bra 1265: vir; 1272: cam; 1376: vir; 1415: nit; 1438: lax; 1502: cam; 1678: vir; 1964: cam; 3896: cam; 4106: tho; 5044: mar; 5135: lax; 5460: cer; 5543 tho; 5824: vir; 6103: cam; 7720: cam; 7745: aca; 7794: gol; 8283: man - Wiland-Szymańska 150: ste; 166: usa; 167: ste; 168: ste - Wild 1597: ste; 5834: ste; 6175: lax - Wilks 1241: tho; 2208: nit; 2621: glo; AP3619: cer - Wingfield 4120: usa; 4503: ste - Wit 1142: con; 2336: man; 2338: per - Wraber 63: man.

Yakbando 94/42: nit - Yamada 213: lax - Yangakola 8: nit - Yongo 318: cer; 773: nit; 872: cer; 878: cam; 920: cam; 1388: nit.

Zawa 781: cam - Zenker 98A!: gol; 219: cam; 1616: con; 2126: lax; 2309: cam; 2313: tho; 2585: bic; 3223: vir; 3809: cam - Zimmermann 2004: usa; 7571: usa.

\section{INDEX}

Accepted names are in roman type. New names are in bold type. Synonyms are in italics. The number after each name is the number of the species as used in this revision.

\author{
Dracaena \\ acaulis Baker 1 \\ acutissima Hua 2 \\ bequaertii De Wild. 12 \\ bicolor Hook. 3 \\ brachythyrsa Peter 21 \\ braunii Engl. 4 \\ buettneri Engl. 9 \\ bushii Damen 5 \\ camerooniana Baker 6 \\ cerasifera Hua 7 \\ congoensis Hua 8 \\ cuspidibracteata Engl. 8 \\ densiflora Baker 3 \\ densifolia Baker 3 \\ gabonica Hua 9 \\ gazensis Rendle 21 \\ glomerata Baker 9 \\ goldieana Bullen ex Mast. \& T.Moore 10
}

\author{
Dracaena (cont.) \\ haemanthoides Bos ex Damen 11 \\ laxissima Engl. 12 \\ forma aureilicia Wiland \& Q. Luke 13 \\ ledermannii Engl. \& K.Krause 22 \\ letestui Pellegr. 22 \\ litoralis Mwachala \& Eb.Fisch. 4 \\ longipetiolata Mwachala \& Eb.Fisch. 20 \\ mannii Baker 14 \\ marina Bos ex Damen 15 \\ mildbraedii K.Krause 22 \\ monostachya Baker var. angolensis Baker 20 \\ nitens Welw. ex Baker 16 \\ oddonii De Wild. 6 \\ perrottetii Baker 17 \\ var. minor Baker 17 \\ poggei Engl. 18 \\ pseudoreflexa Mildbr. 21 \\ reflexa Lam. var. buchneri Engl. 16
}

\author{
Dracaena (cont.) \\ rubroaurantiaca De Wild. 1 \\ sanderiana Sander ex Mast. 18 \\ silvatica Hua 6 \\ soyauxiana Baker 9 \\ steudneri Engl. 19 \\ talbotii Rendle 3 \\ tessmannii Engl. \& K.Krause 14 \\ tholloniana Hua 20 \\ thomensis Dandy 12 \\ usambarensis Engl. 21 \\ var. angustifolia Peter 21 \\ var. longifolia De Wild. 14 \\ vanderystii De Wild. 18 \\ viridiflora Engl. \& K.Krause 22 \\ wakaensis Damen \& Quiroz 23 \\ waltersiae Damen 24 \\ Lucky Bamboo 18 \\ Pleomele heudelotii N.E.Br. 17 \\ Sansevieria longifolia Welw. 1
}

